WATER RESOURCES OF SOUTHEASTERN OAHU, HAWAII

By K. J. Takasaki and J. F. Mink

U.S. GEOLOGICAL SURVEY

Water-Resources Investigations 82-628

Prepared in cooperation with the

BOARD OF WATER SUPPLY

CITY AND COUNTY OF HONOLULU

Honolulu, Hawa i i

November 1982 


\section{UNITED STATES DEPARTMENT OF THE INTERIOR \\ JAMES G. WATT, Secretary}

GEOLOGICAL SURVEY

Dallas S. Peck, Director

For additional information write to:

District Chief

U.S. Geological Survey, WRD

Rm. 6110, 300 Ala Moana Blvd.

Honolulu, Hawai i 96813
Copies of this report

may be purchased from:

Open-File Services Section Western Distribution Branch

U.S. Geological Survey

Box 25425, Federal Center

Lakewood, Colorado 80225

(Telephone: [303] 234-5888) 


\section{CONTENTS}

Abstract

Introduction

Well-numbering system 5

Geologic framework

Brief history 6

Geologic and structural features and their hydrologic significance 6

Main fissure zone 8

Caldera -

Minor rift zones

Honolulu Group

Water-bearing properties of rock units and the occurrence

of ground water in them 11

Water development

Hydrology - 17

Rainfall - 17

Evapotranspiration 17

Streams - 22

Ground water 22

Water resources of selected subareas

Windward (northside) of Koolau crest 23

Maunawili Valley 23

Geologic setting 23

Streams - 25

Ground water - 26

Dike-impounded water - 26

Perched water _- 29

Basal water - 30

Water-level fluctuations - 30

Past and potential development 30 
Hydrology--Cont i nued

$$
\begin{aligned}
& \text { Water resources of selected subareas--Continued } \\
& \text { Windward (northside) of Koolau crest--Continued }
\end{aligned}
$$$$
\text { Waimanalo area - } 35
$$$$
\text { Geologic setting - } 35
$$$$
\text { Streams - } 39
$$$$
\text { Ground water - } 39
$$

Dike-impounded water - 39

Perched water - 39

Water confined in deep sedimentary material- 41

Basal water in coastal-plain sediments ----- 41

Past and potential development --- 48

Makapuu area - 51

Leeward (southside) of Koolau crest -_- 54

Hawai i Kai (Maunalua) area - 54

Geologic setting - 54

Water - 54

Kuliouou-Waialae area 60

Geohydrologic setting 60

Streams -

Ground water - 67

Dike-impounded water - 67

Perched water - 68

Basal water - 68

Past and potential development -.-.-- 83

Summary of water development in southeastern 0ahu -.-- 84

References - 87 


\section{ILLUSTRATIONS}

Figure

Page

1. Map showing Southeast 0 ahu and the area of study

2. Map of I sland of Oahu showing $r$ ift zones and calderas

of Koolau and Waianae Volcanoes

3. Map of southern part of 0ahu showing dikes associated with

the dike complex, marginal dike zone, Kaau rift, Koko

rift and other minor $r$ ifis

4. Generalized geologic map of southeast Oahu 13

5. Graphs showing municipal reservoir capacities in southeast 0ahu

6. Map of southeastern 0ahu showing distribution of mean annual rainfall

7. Graph showing the percentage increase by months above the median June rainfall for gages 794 and 789 for the period of record

8. Graphs showing relation of pan evaporation to rainfall for selected gages

9. Geologic map of Maunawili Valley showing location of wells and tunnels

10. Relative altitudes of water levels in wells, tunnels, water-level gradient of dike-impounded water, and base-flow measuring points in streams in

Maunawili Valley

11. Section showing possible water-level gradient across the Koolau crest and percentage gain in low flow of streams with decreasing altitude

12. Map of Coconut Grove area showing water-level contours

13. Water-level fluctuations of Maunawili Valley wells

tapping rocks in the dike complex, marginal dike zone,

and calcareous sediments

14. Generalized geologic section of coastal plain in Waimanalo area

15. Geologic map of Waimanalo area showing location of drilled wells and tunnels 


\section{ILLUSTRATIONS--Cont i nued}

Figure

16. Relative altitudes of water levels in wells, tunnels, water-level gradient of dike-impounded water, and base-flow measuring points in streams in the Waimanalo area

17. Stratigraphic section drawn from core logs in the

Waimanalo area

18. Graphs showing results of pumping test of drainage

ditch in the Waimanalo area

19. Graphs showing results of pumping test in a temporary

dug well in Waimanalo State Park

20. Geologic map of the Makapuu area showing location of wells -.-

21. Map of Hawaii Kai area showing landscape features of

Honolulu Group and position of former shoreline

22. Geologic map of Hawai Kai area showing location of

drilled wells and chloride concentration of water in

the wells

23. Map of Hawai $\mathrm{Kai}$ area showing location of dug wells, springs, and the range in chloride concentration of the water in them

24. Geologic map of Kuliouou-Waialae area

25. Map of 0ahu showing isopiestic areas 63

26. Structural section through Diamond Head, Kaimuki Crater, and Puu Mauumae

27. Map of Kuliouou-Waialae area showing location of selected wells and distinctive basal-water reservoirs of different heads

28. Section $\left(B-B^{1}\right)$ across volcanic spurs at the 400-foot contour showing thickness of basal-water reservoirs

29. Section $\left(A-A^{1}\right)$ across volcanic spurs at the 1,000-foot contour showing thickness of basal-water reservoirs

30. Head correlation between isopiestic areas 1 and 5

31. Graph showing relation between pump rate and drawdown 


\section{TABLES}

Table

Page

1. Water-bearing properties of the rocks and occurrence

of ground water in them in southeast 0ahu

2. Distribution in the equivalent volume of annual rainfall

between selected lines of equal rainfall 19

3. Tunnels and wells in Maunawili Valley

4. Tunnels and wells in Waimanalo

5. Wells in Makapuu area

6. Wells in Hawai $\mathrm{Kai}$ area

7. Waialae shaft (1747-02) pump-test data and computations, June 10-20, 1936

8. Specific capacities and specific capacities per foot

of aquifer penetration for wells tapping basaltic aquifers in Koolau Range 79

9. Wells in the Kuliouou-Waialae area

10. Summary of water development in Southeastern Oahu 


\section{CONVERSION TABLE}

The following table may be used to convert measurements in the inch-pound system to the International System of Units (SI).

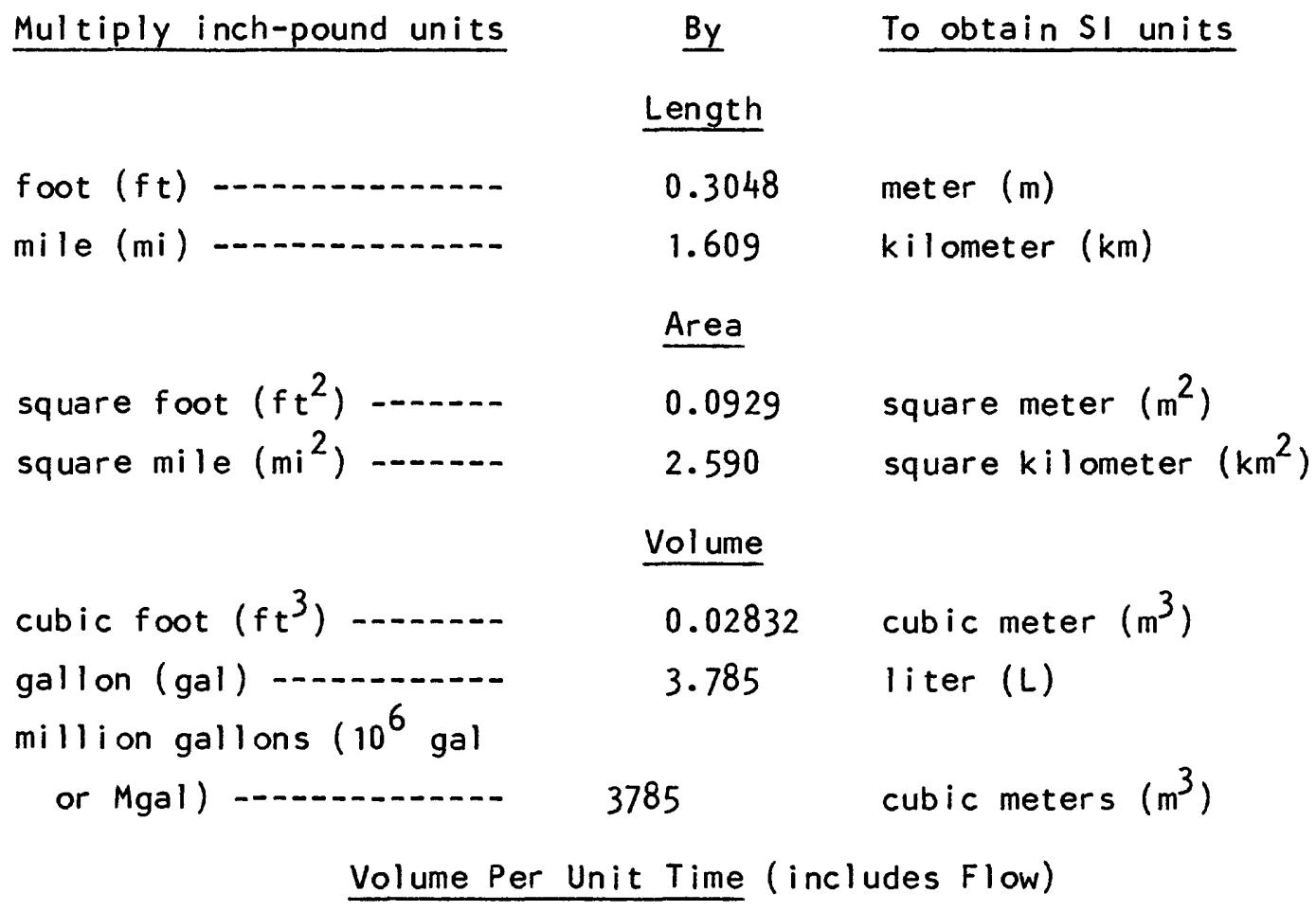

Volume

cubic foot $\left(\mathrm{ft}^{3}\right)$
gallon (gal)
million gallons $\left(10^{6} \mathrm{gal}\right.$

or Mgal)

0.02832 cubic meter $\left(\mathrm{m}^{3}\right)$

3.785 liter (L)

\section{Volume Per Unit Time (includes Flow)}

cubic foot per second

$$
\left(\mathrm{ft}^{3} / \mathrm{s}\right)
$$

cubic foot per second-day

$$
\left(\mathrm{ft}^{3} / \mathrm{s}-\mathrm{d}\right)
$$

gallon per minute (gal/min)

$$
0.06309 \text { liter per second (L/S) }
$$

million gallons per day

$$
\left(10^{6} \mathrm{gal} / \mathrm{d} \text { or Mgal } / \mathrm{d}\right) \text {-- }
$$

\begin{tabular}{|c|c|c|}
\hline foot per mile $(\mathrm{ft} / \mathrm{mi})$ & 0.1894 & meter per kilometer $(\mathrm{m} / \mathrm{km})$ \\
\hline foot per day $(f t / d)$ & 0.3048 & meter per day $(\mathrm{m} / \mathrm{d})$ \\
\hline gallon per minute per foot & & liter per second per meter \\
\hline$[(\mathrm{gal} / \mathrm{min}) / \mathrm{ft}] \ldots$ & 0.207 & {$[(\mathrm{~L} / \mathrm{s}) / \mathrm{m}]$} \\
\hline $\begin{array}{l}\text { foot squared per day }\left(\mathrm{ft}^{2} / \mathrm{d}\right) \\
\text { micromho per cent imeter }\end{array}$ & 0.0929 & $\begin{array}{l}\text { meter squared per day }\left(\mathrm{m}^{2} / \mathrm{d}\right) \\
\text { microsiemens per cent imeter }\end{array}$ \\
\hline$(\mu \mathrm{mho} / \mathrm{cm})$ & 1.000 & $(\mu S / \mathrm{cm})$ \\
\hline
\end{tabular}

0.04381 cubic meter per second $\left(\mathrm{m}^{3} / \mathrm{s}\right)$

Miscellaneous 


\title{
WATER RESOURCES OF SOUTHEASTERN OAHU, HAWAII
}

\author{
By K. J. Takasaki and J. F. Mink
}

\section{ABSTRACT}

Southeastern Oahu comprises the eastern end of the Koolau Range and is divided into two roughly equal parts by the crest of the range. The northside of the crest is commonly called the windward side and the southside, the leeward. Precipitous cliffs aproned by a gently sloping landscape are the main topographic features on the windward side. The leeward side is a gentle lava-flow slope incised by steep narrow valleys.

The main Koolau fissure zone, including the caldera, lies on the windward side. The leeward side includes minor rift zones that are perpendicular to and intersect the main fissure zone. Dikes in the main fissure zone strike from nearly east-west in the eastern end to about $N .55^{\circ} \mathrm{W}$. in the western part. Dikes in the minor rift zones strike from north-south to slightly nor theasterly.

Water use is about $18 \mathrm{Mgal} / \mathrm{d}$ (million gallons per day) of which only 4 $\mathrm{Mgal} / \mathrm{d}$ is obtained locally from ground-water sources. About a third of the 14 Mgal/d deficit is imported from sources northwest of the study area on the windward side and the remainder from sources in the Honolulu and Pearl Harbor areas on the leeward side. The $4 \mathrm{Mgal} / \mathrm{d}$ being developed represents only about 3 percent of the area's rainfall compared to a development-rainfall ratio of 20 percent for the rest of the island.

Streams are short and flashy. Perennial streamflow to the sea occurs only in Maunawili Valley and in the Waimanalo area. Mean annual discharge is estimated at $20 \mathrm{Mgal} / \mathrm{d}$ in the windward side and at $15 \mathrm{Mgal} / \mathrm{d}$ on the leeward side. Low flow, expressed as the flow that is equaled or exceeded 90 percent of the time, is $5 \mathrm{Mgal} / \mathrm{d}$ windward of the crest and zero leeward of it. 
Most fresh ground water occurs in lava flows of the Koolau Volcanics. It is impounded by dikes in the rift zones and floats on saline ground water as lenses outside the rift zones. Small but important bodies of freshwater are perched in volcanic rocks of the Honolulu Group in Maunawili Valley.

Fresh ground water occurs in near-shore calcareous sands that overlie a clay horizon in the Waimanalo area. Deeply buried talus and alluvium also carry fresh ground water in the Waimanalo area.

Wells tapping saline ground water in fresh lava flows of the Honolulu Group provide water for a sea-life park in the Makapuu area. The same aquifer is tapped by wells for disposal of the saline waste water.

The current development scheme in the windward side that utilizes only the free-flow equilibrium discharge of dike-impounded water is inefficient and does not cope with the annual weather cycle. The flow available for development under this scheme is greatest in the rainy winter months when demand is the lowest and least in the summer months when demand is the highest. A more optimal scheme would be to change this natural flow pattern by depleting storage by pumping to increase flow in the high-demand summer months and allowing the depleted storage to recover naturally in the lowdemand winter months. Depleting storage would lower water levels which would provide more room for infiltration and provide less opportunity for evapotranspiration.

The basal-water reservoir in the leeward side is isolated hydrologically from abutting reservoirs outside the area and can and should be fully exploited. The existing development of the basal-water reservoir is small compared to the natural ground-water flow and that part not being developed is wasting to the sea. Because the area is hydrologically isolated, development will not be detrimental to or reduce the ground-water supply outside the area. 


\section{INTRODUCTION}

Southeastern Oahu comprises the eastern end of the Koolau Range and is divided into two roughly equal parts by the erest of the range. The study area, has an area of 55 square miles and receives an overall average annual rainfall of about 50 inches. The rainfall is equivalent to $125 \mathrm{Mgal} / \mathrm{d}$ (million gallons per day). The Koko Head Natural Park area was not included in summarizing the rainfall because this area has very low rainfall and is hydrologically and geologically isolated from the main mountain mass. The area of study is shown in figure 1.

Southeastern Oahu contains several highly developed residential communities that were nonexistent at the end of World War II. The population of the area then, less than 10 percent of that in 1980, was centered in the Waimanalo and Kailua town areas in the windward (north) side of the crest and scattered along the shoreline areas in the leeward (south) side. Despite the tremendous growth in population during the past 35 years from less than 10,000 to about 100,000 , development of new municipal water sources within the areas has been less than $1 \mathrm{Mgal} / \mathrm{d}$. Water use in the area is about $18 \mathrm{Mgal} / \mathrm{d}$ compared to $4 \mathrm{Mgal} / \mathrm{d}$ that is now being developed. Roughly, a third of this deficit of $14 \mathrm{Mgal} / \mathrm{d}$ is imported from sources northwest of the study area in the windward side and the other two-thirds from sources in the western part of Honolulu and the Pearl Harbor area.

The $4 \mathrm{Mgal} / \mathrm{d}$ of ground water being developed in the area is less than 3 percent of the area's rainfall of $125 \mathrm{Mgal} / \mathrm{d}$ derived from an average annual rainfall of 50 inches. This percentage is significantly lower than that of the island, taken as a whole, of 20 percent, where ground-water draft is about $400 \mathrm{Mgal} / \mathrm{d}$ compared to a rainfall of $2,000 \mathrm{Mgal} / \mathrm{d}$, derived from an average annual rainfall of 70 inches.

The principal objective of this study was to determine the ground-water supply available and to locate the most favorable sites in the area for additional development. 


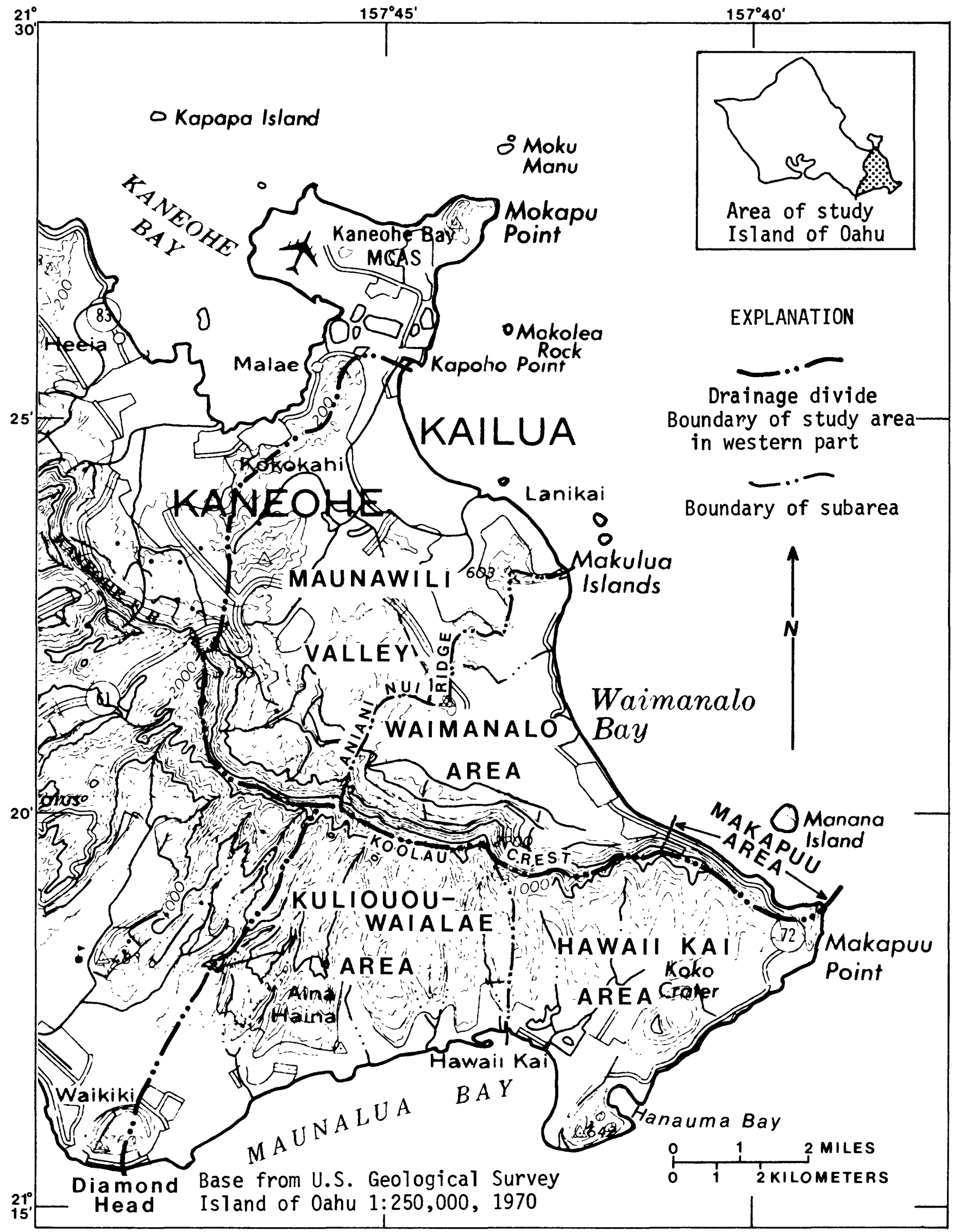

Figure 1. Southeast 0ahu and the area of study. 
Any additional water supplies that can be developed in the study area would decrease the amount to be imported. In much of the central part of leeward 0ahu where water development is extensive, additional water supplies can be developed only at the expense of reducing existing supplies or by degrading their quality. This is not the case in southeastern 0ahu where the hydrologic and geologic framework is such that development of new supplies would not reduce nor degrade the supply now being developed in leeward central Oahu.

The hydrologic and geologic features that control availability of water are described in this report and, where determinable, the sustainable yield of water in the study area is given. The report is also concerned with the quantity of water being imported into the area because much of it is from the heavily pumped Pearl Harbor area.

\section{WELL-NUMBERING SYSTEM}

The well-numbering system used is based on latitude and longitude. The Island of 0ahu is subdivided into rectangles by the 1 -minute parallels and meridians, the rectangles measuring about a mile on each side. Each rectangle is located by a four-digit number consisting of minutes of latitude followed by minutes of longitude.

Within each rectangle, the wells are numbered serially according to the time drilled, where known. The well number then consists of a four-digit number that identifies the rectangle, followed by a hyphen and a two-digit serial number. The 1-minute rectangular grid system provides a nonduplicable system for the Island of Oahu because 0ahu encompasses an area which is less than 1 degree of latitude or longitude. 


\title{
GEOLOGIC FRAMEWORK
}

\author{
BRIEF HISTORY
}

Oahu was formed through the building and coalescing of the Waianae and Koolau Volcanoes. The study area includes the southeastern part of Koolau, the younger of the two volcanoes.

The Koolau volcanic dome was once a typical Hawai ian shield volcano with a collapsed caldera near its summit. Two principal $r$ ift zones which compose the main fissure zone of the volcano meet in the collapsed summit region in the caldera. The principal rift zones, the northwest and southeast, meet at an angle of about 165 degrees where a minor rift zone, the Kaau, extends from the apex of the exterior angle formed by the two principal rifts (fig. 2). other small rifts manifested by many dikes lie in the area east of the minor $r$ ift zone.

Extensive erosion has removed much of the caldera structure and the lavas that ponded in the caldera. The present topography, where Kawainui Swamp is the center of the caldera and the Koolau crest is a much eroded extension of the caldera wall, is the result of this extensive erosion. The rocks produced during the initial phase of volcanic activity and caldera collapse belong to the Koolau Volcanics.

Much of the erosion occurred during the long period of quiescence following the initial mountain-building phase. This period was followed by renewed volcanic activity in southeastern Oahu that produced volcanic rocks of the Honolulu Group.

\section{Geologic and Structural Features and Their Hydrologic Significance}

The main fissure zone including the caldera on the windward side of the crest and the minor rifts on the leeward side are the principal structural features of the Koolau Volcano controlling the occurrence, movement, and discharge of ground water. Volcanic rocks of the Honolulu Group are confined to small scattered exposures or to shoreline areas and generally have little hydrologic significance. 


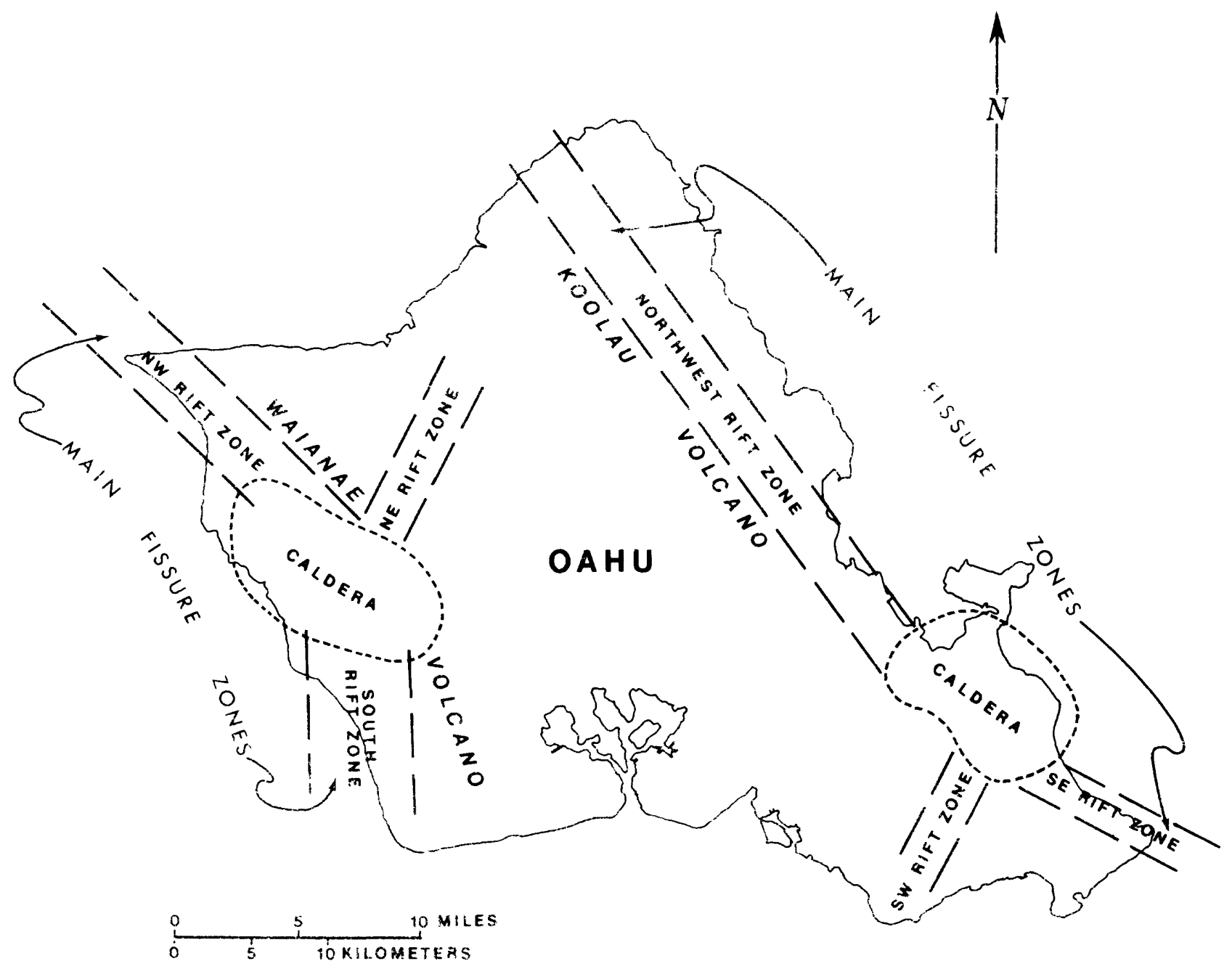

Figure 2. Rift zones and calderas of Kcolau and Waianae volcanoes on the island of Oahu (modified from Macdonald, 1972). 
Main Fissure Zone

The main fissure zone from which the bulk of the Koolau lavas emanated includes the two principal rift zones (fig. 2). That part of the main fissure zone which includes the southeast $r$ ift zone and the southeast part of the caldera is included in the area of study. This fissure zone, where exposed at great depths by erosion, is marked by numerous dikes. Dikes are in greatest abundance in the central part of the zone, where the number of dikes averages more than 100 per mile and can be as much as 1,000 per mile of horizontal distance (Macdonald, 1956). The number of dikes decreases sharply towards the adjacent outer part to between 10 and 100 per mile, and at the edge, the number drops off abruptly (Macdonald and Abbott, 1970).

The term "dike complex" has been used (Stearns and Vaksvik, 1935) to describe the central part of the fissure zone where the number of dikes averages more than 100 per mile and generally makes up more than 10 percent of the total rock volume. Where the dikes number fewer than 100 per mile and constitute less than about 5 percent of the total rock volume, the term "marginal dike zone" has been used (Stearns and Vaksvik, 1935). The strike or alinement of the dikes is generally the same in these zones, and in the field these zones are generally distinct and identifiable because of the abrupt change in the number of dikes between them.

Dikes in the dike complex and the marginal dike zone in and near the caldera area intersect and strike in the direction of the converging rift zones. The strike of the intersecting dikes is predominantly $\mathrm{N} .55^{\circ} \mathrm{W}$. in the northwest rift, N. $75^{\circ} \mathrm{W}$. in the southeast $r i f t$, and $N .30^{\circ} \mathrm{E}$. in the minor southwest or Kaau rift (Takasaki, Hirashima, and Lubke, 1969). Away from the caldera area, the dikes in the southeast $r$ ift show a gradual shift in strike from $\mathrm{N} .75^{\circ} \mathrm{W}$. near the caldera to nearly east-west at the eastern end of the island. The alinement of dikes and delineation of the dike complex and marginal dike zone in the southeastern part of Dahu are shown in figure 3. 


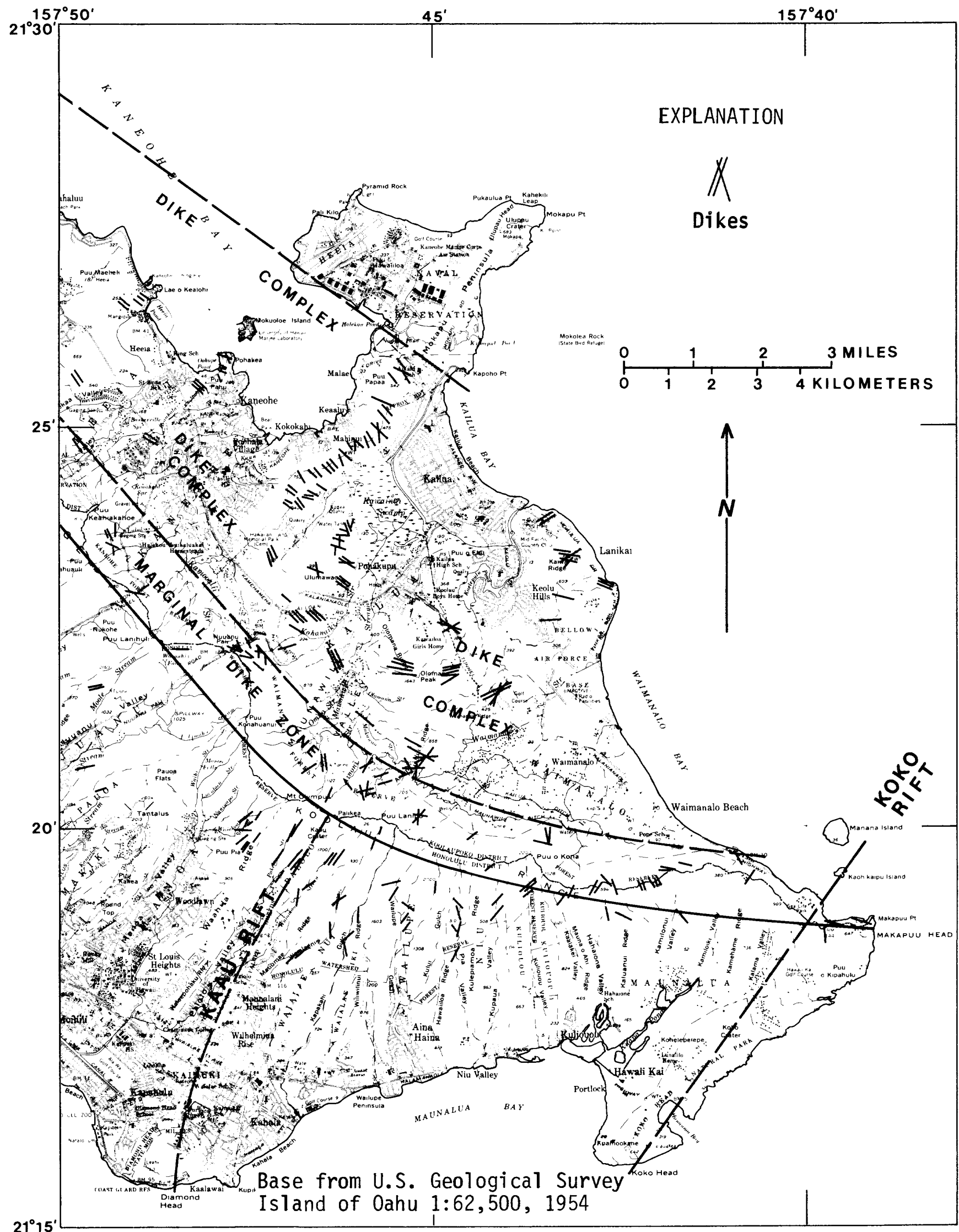

Figure 3. Dikes associated with the dike complex, marginal dike zone, Kaau rift, Koko rift and other minor rifts in the southern part of Oahu (modified from Takasaki and Mink, 1981). 
The dike complex, owing to the abundance of dikes and the likel ihood of the dikes intersecting, is generally a poor-yielding reservoir of water even though ground water is impounded in it tu very high levels. More favorable conditions for the development of dike-impounded ground water are found in the marginal dike zone where dikes are sparse and their intersection less common. In general, the dike complex acts as a deterrent to ground-water flow in all directions, whereas the marginal dike zone is a deterrent to flow primarily in the direction normal to the dikes.

\section{Caidera}

The junction of the rift zones lies in a caldera, whose eroded extension is about 8 miles long and 4 miles wide. Lavas continued to erupt from the rifts in and out of the caldera even after its collapse so that lavas erupting within the caldera walls were contained and ponded. Thick massive ponded lavas and breccia produced by the collapsing caldera walls are the principal rock types in the caldera. These rocks, low in permeability to begin with, were subsequently altered by rising volcanic gases, which lowered their permeability even further. Although these rocks are nearly saturated, their ability to transmit water is low and they generally comprise poor yielding reservoirs of water.

Minor Rift Zones

The number of dikes in the Kaau rift, the dominant minor rift in the lee of the crest, is much less than 100 per horizontal mile. Dikes are even less numerous in the other minor rifts east of the Kaau rift. Because of the reduced number of dikes, the intruded lavas are similar in structure to lavas in the marginal dike zone and act similarly in their control of ground water. 
The strike or alinement of the dikes in the leeward rift zones generally parallels the lava-flow direction and, in this case, also the ground-water flow direction. This alinement is far less optimal for water impoundment than that of the windward side where dikes cut across the lava flows and the dominant ground-water-flow direction.

The dikes in the Kaau rift strike predominantly N. $30^{\circ} \mathrm{E}$. Dikes in the other rifts east of Kaau show a gradual shift in trend from nor theast to north away from the Kaau rift.

\section{Honolulu Group}

Volcanic rocks of the Honolulu Group, except in Maunawili Valley, are limited to shoreline areas and carry little or no freshwater. In Maunawili Valley, lava flows of this group lie unconformably on alluvium and the weathered surface of Koolau rocks and carry freshwater in perched bodies. Lava flows of the Honolulu Group are generally thicker and more massive than the flank flows of the Koolau Volcanics.

\section{WATER-BEARING PROPERTIES OF ROCK UNITS AND THE OCCURRENCE OF}

\section{THE GROUND WATER IN THEM}

Rocks in southeastern 0ahu consist principally of dike-free and dikeintruded lava flows, breccia, cinders, tuff, and sedimentary material of volcanic origin. The coastal plain includes sedimentary rocks of volcanic origin, clay, coral, calcareous beach sand, and dunes of calcareous material.

The water-bearing properties of the rock units and occurrence of ground water in them are summarized in table 1. Distribution of the principal rock types is shown in the generalized geologic map (fig. 4 ). 
Table 1. Water-bearing properties of the rocks and occurrence of ground water in them in southeast 0ahu

\begin{tabular}{|c|c|c|c|c|c|c|}
\hline \multirow[b]{2}{*}{ Rock type } & \multirow[b]{2}{*}{ Permeability } & \multirow{2}{*}{\multicolumn{3}{|c|}{$\begin{array}{l}\text { Hydraulic } \\
\text { conductivity } \\
(\mathrm{ft} / \mathrm{d})\end{array}$}} & \multicolumn{2}{|c|}{$\begin{array}{l}\text { Ground-water } \\
\text { occurrence }\end{array}$} \\
\hline & & & & & Principal & Secondary \\
\hline \multicolumn{7}{|l|}{$\begin{array}{l}\text { Sedimentary material } \\
\text { Coral }\end{array}$} \\
\hline In situ & Moderate to high & 100 & $<K<$ & 1000 & Basal & Perched. \\
\hline Reworked & Low to moderate & 1 & $<K<$ & 500 & do. & Do. \\
\hline Consolidated & Low & 1 & $<K^{<}$ & 100 & do. & Do. \\
\hline Unconsol i dated & Moderate to high & 100 & $<K^{<}$ & 1000 & do. & Do. \\
\hline \multicolumn{7}{|l|}{ Dunes } \\
\hline In situ & Low to moderate & 1 & $<K^{<}$ & 500 & Perched & Basal. \\
\hline Reworked - & do. & 1 & $<K<$ & 500 & Basal & Perched. \\
\hline Consolidated & Low & 1 & $<K<$ & 100 & Perched & Basal. \\
\hline Unconsoli dated & Low to moderate & 1 & $<K<$ & 500 & Basal & Perched. \\
\hline \multicolumn{7}{|c|}{ Sand } \\
\hline Consolidated & Low to moderate & 1 & $<K<$ & 500 & Basal & \\
\hline Unconsol i dated & Moderate to high & 100 & $<K^{<}$ & 1000 & do. & \\
\hline \multicolumn{7}{|c|}{ Lagoonal } \\
\hline \multicolumn{7}{|l|}{ In situ } \\
\hline Consolidated $\ldots$ & Low & 1 & $<K<$ & 100 & Basal & \\
\hline Unconsolidated ..... & Low to moderate & 1 & $<K<$ & 500 & do. & \\
\hline \multicolumn{7}{|c|}{ Muds } \\
\hline \multicolumn{7}{|l|}{ In situ } \\
\hline Consolidated $\ldots$ & Very low & & $K<$ & 1 & Perched & \\
\hline Unconsolidated ..... & Very low & & $K<$ & 1 & do. & \\
\hline \multicolumn{7}{|c|}{ Alluvium } \\
\hline \multicolumn{7}{|l|}{ Younger } \\
\hline In situ & Low to moderate & 1 & $<K<$ & 500 & Perched & Perched. \\
\hline Unconsoli dated & do. & 1 & $<K^{<}$ & 500 & do. & Do. \\
\hline \multicolumn{7}{|l|}{ Older } \\
\hline 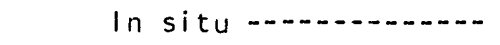 & Very low & & $K<$ & 1 & Perched & \\
\hline Reworked & do. & & $K^{<}$ & 1 & do. & \\
\hline Consolidated & do. & & $k^{<}$ & 1 & do. & \\
\hline Unconsoli dated & Low & 1 & $<K<$ & 100 & do. & Basal. \\
\hline \multirow{3}{*}{\multicolumn{7}{|c|}{$\begin{array}{l}\text { Volcanic } \\
\text { Honolulu Group } \\
\text { Inside caldera }\end{array}$}} \\
\hline & & & & & & \\
\hline & & & & & & \\
\hline Lava flows & Low to moderate & 1 & $<K<$ & 500 & Perched & \\
\hline Cinders & Low & 1 & $<K<$ & 100 & do. & \\
\hline Tuff & Low & 1 & $<K<$ & 100 & do. & \\
\hline \multirow{2}{*}{\multicolumn{7}{|c|}{$\begin{array}{l}\text { Outside caldera } \\
\text { Lava flows }\end{array}$}} \\
\hline & & & & & & \\
\hline Dike complex .............. & Low to moderate & 1 & $<K<$ & 500 & do. & \\
\hline Marginal dike zone - & do. & 1 & $<K<$ & 500 & do. & \\
\hline Dike-free & High to very high & 500 & $\langle K\rangle$ & 1000 & Basal & Perched. \\
\hline Cinders & Low to moderate & 1 & $<K<$ & 500 & Perched & \\
\hline Tuff $\ldots \ldots \ldots$ & Low & 1 & $<K<$ & 100 & Basal & Perched. \\
\hline Saprolite & Very low & & $K<$ & 1 & Perched & \\
\hline Koolau Volcanics & & & & & & \\
\hline Inside caldera & & & & & & \\
\hline Lava flows & Low & 1 & $<K<$ & 100 & Dike- & \\
\hline & & & & & impounded & Perched. \\
\hline Breccia & do. & 1 & $<K<$ & 100 & Perched & \\
\hline Outside caldera & & & & & & \\
\hline Dike complex & Low to moderate & 1 & $<K<$ & 500 & Dike- & \\
\hline Marginal dike zone-- & Moderate to high & 100 & $<K<$ & 1000 & $\begin{array}{l}\text { impounded } \\
\text { do. }\end{array}$ & $\begin{array}{l}\text { Perched. } \\
\text { Basal. }\end{array}$ \\
\hline Dike-free ............... & Very high & & $K>$ & 1000 & Basal & \\
\hline Breccia & Low & 1 & $<K<$ & 100 & Perched & \\
\hline $\begin{array}{l}\text { Saprolite (highly } \\
\text { weathered rock) }\end{array}$ & Very low & & $K^{<}$ & 1 & do. & \\
\hline
\end{tabular}




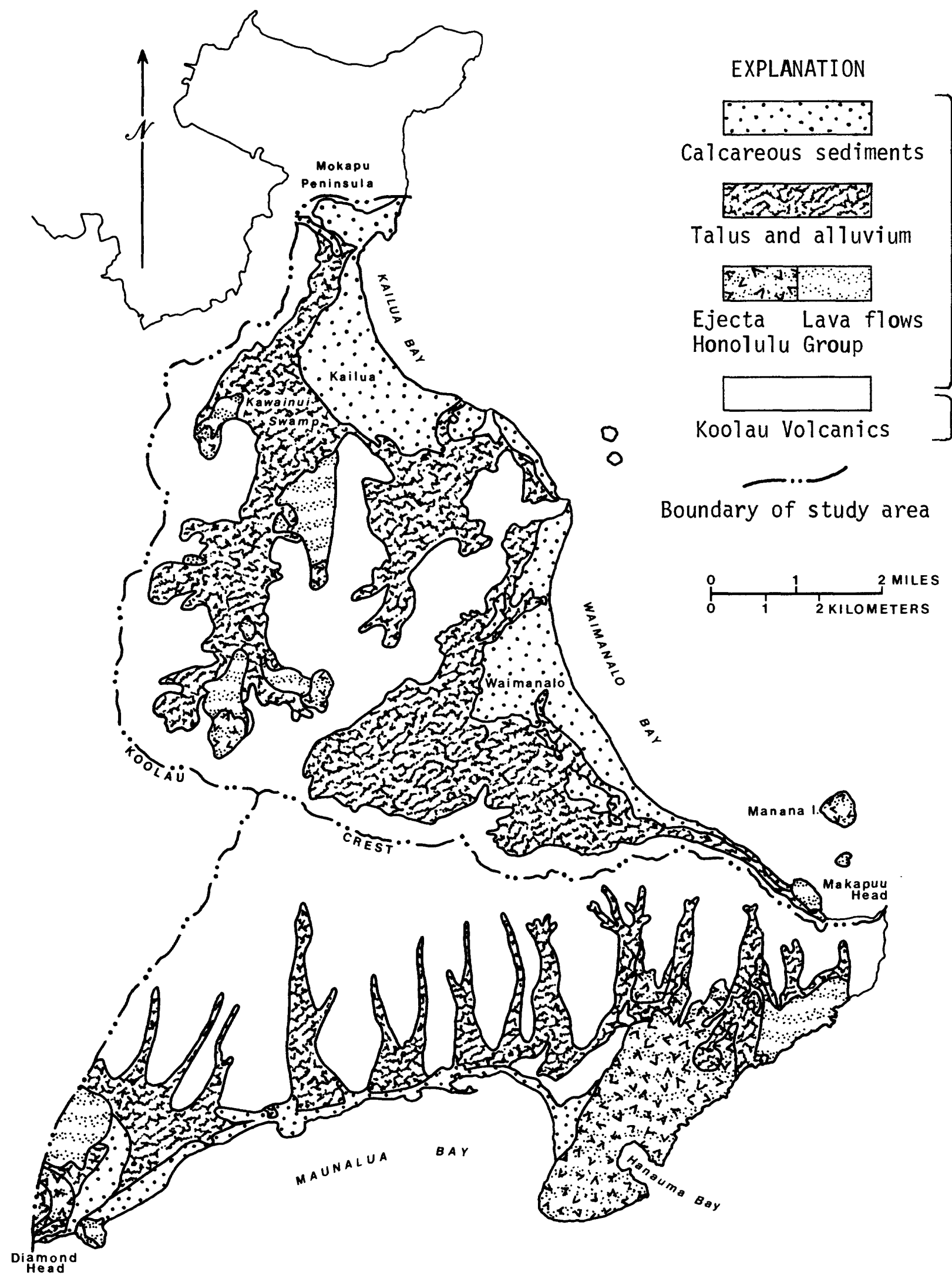

Figure 4. Generalized geologic map of southeast Oahu (from Stearns, 1939). 


\section{WATER DEVELOPMENT}

Early development on the windward side consisted of the simple diversion of water from springs and spring-fed streams for domestic use and irrigation of taro and rice. Maunawili ditch was constructed in 1878 to transport water from Maunawili Valley to the Waimanalo area for the irrigation of sugarcane. By 1900, Waimanalo Sugar Co. had 1,900 acres of sugarcane under cultivation. During dry spells, water was pumped from a swamp lagoon located at the present site of Olomana Golf Links. In 1923, the company added to its supply of irrigation water by pumping water from Kawainui Swamp in Maunawili Valley and transporting this water through a tunnel and ditch system to the Waimanalo area.

Simple diversions gave way to tunneling mostly at or near springs. The earliest tunnel reportedly was dug in 1888 and the latest in 1940, both in the upper Waimanalo area.

The first public water system in Waimanalo was installed by the then Territorial Government in 1926 to serve the Waimanalo Beach Lots (Austin, 1925). The source of supply was an existing tunnel. In 1940, another tunnel was added to augment the supply. During World War 11 , water had to be brought in from the Kaneohe-Kailua section of the County water system to meet the growing demands of Bellows Field.

The Waimanalo Sugar Co. was liquidated in 1947 and the responsibility of supplying domestic water in the Waimanalo area shifted from the sugar company to the County. The Waimanalo Agricultural Development Co. was formed and it acquired land and water leases in 1947 from the sugar company. At the same time, the Development Company took over the water licenses, which covered the use of water from upper Maunawili Valley and Kawainui Swamp. The water licenses expired in 1953, at which time the Territory of Hawaii took over. The Territory, now the State, has since been in the process of subdividing and selling small farm lots to qualified farmers. 
Except for the early years when domestic water was piped from springs in upper Maunawili Valley and during a short interim period when water was pumped from a drilled well, all municipal water supply in Maunawili Valley was and still is derived from sources outside the study area. Private water systems in Maunawili Valley included the Koolau and Kawailoa Training School Systems and the Kaimi Farm System. The source of the training school system, was Api Spring and two drilled wells. Kaimi Farm derived its water from Omao Spring; it was used only for the dairy supply as the water was determined to be unfit for human consumption. Both of the systems are now defunct.

During the 10-year period following World War 11 , the principal water use in the study area gradually shifted from irrigation to municipal supply. This resulted from the abatement of truck-farming activities in the Kailua area, liquidation of the Waimanalo Sugar Co., and budding subdivision activities in windward Uahu.

Early development in the leeward side consisted mainly of collecting springflow that issued from some of the toes of volcanic spurs or of pumping from shallow dug wells in coral near the shore. A few small springs issuing from tuff deposits in the Hawai Kai area provided water for some farms in that area.

The three earliest wells that tapped artesian water in Isopiestic Area 5 , a designation given to the area between Palolo and Wailupe Valleys by the Honolulu Board of Water Supply, were drilled in about 1882 (McCandless, 1936). The water reportedly rose to 8 feet above sea level and tasted brackish. These wells are lost. According to McCandless, two more wells were drilled in 1889 to supply water for cattle and to irrigate alfalfa. The water from these wells was potable and had a head of 8 feet. These wells, 1646-01 and 1646-02, are on the present site of the Waialae Golf Course.

The first municipal supply source, shaft 7 (1747-02), was constructed in 1937. Subsequent municipal-supply wells were drilled in 1968, 1973 and 1981. Figure 5 shows the municipal reservoir capacities in southeastern 0ahu from 1935 in the leeward side and from 1941 in the windward side to 1980. The reservoir capacity is roughly equated to 1-1/2 times the average daily use by the Honolulu Board of Water. 

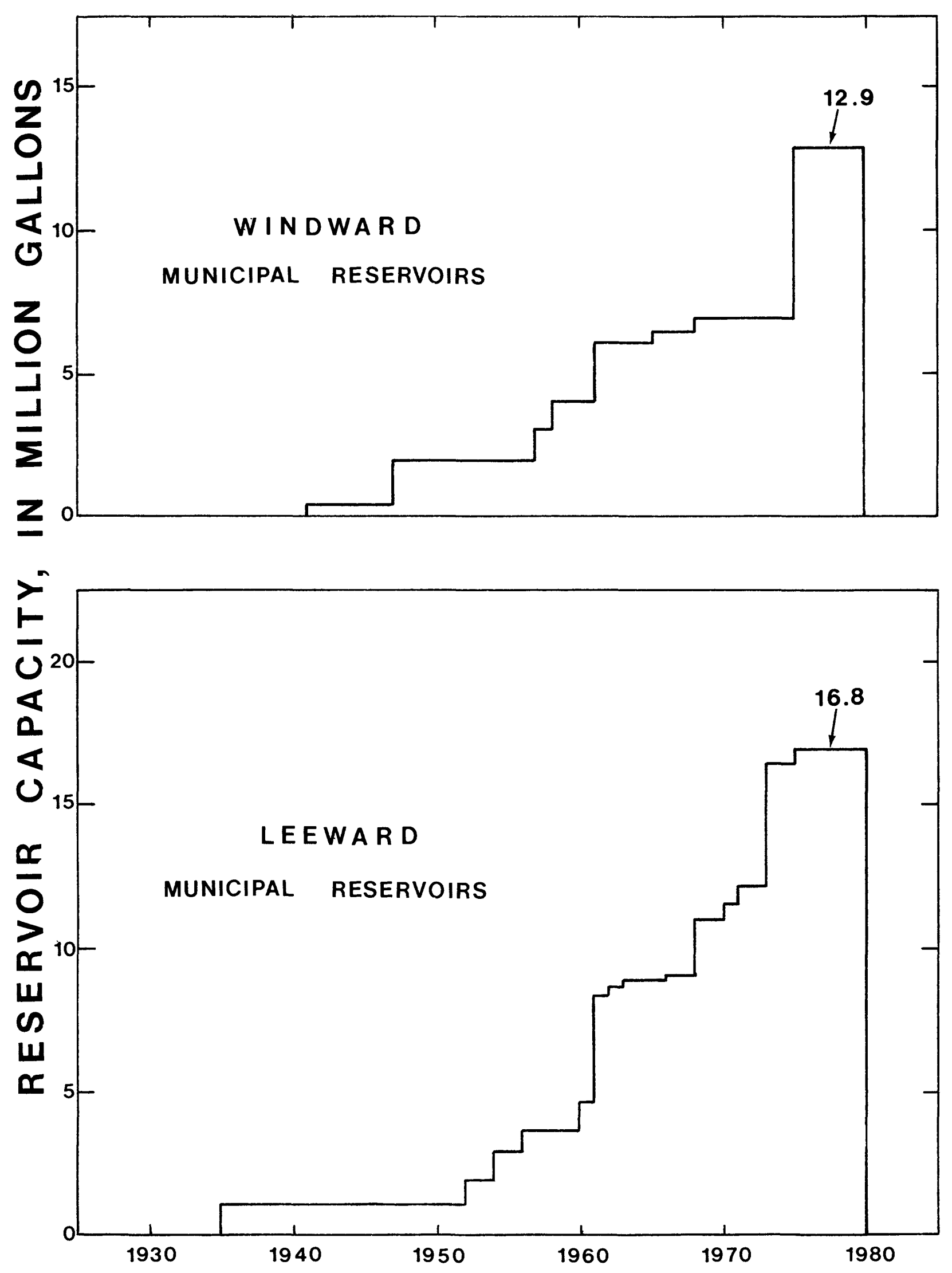

Figure 5. Municipal reservoir capacities in southeast 0ahu. 
HYDROLOGY

RAINFALL

Rainfall in southeastern Oahu is highest near the head of Maunawili Valley where the Koolau crest reaches an altitude of more than 3,000 feet. The rainfall there exceeds 125 inches a year and is caused by upwelling of the northeast trade winds as they move across the Koolau Range. Southeast of Maunawili Valley where the crest is not as high, the orographic effect on the trade winds is reduced resulting in markedly lower rainfall. The distribution of mean annual rainfall in southeastern 0ahu is shown in figure 6. The volume of annual rainfall between selected lines of equal rainfall in different areas is shown in table 2 .

The trade winds blow more than 75 percent of the time, and where the rainfall extracted from them is high, as in the wet interior mountains, the distribution of this rainfall is fairly even throughout the year. Where the orographic or trade-wind-extracted rainfall is low, as in the coastal areas, the distribution is very uneven, with most of the rainfall occurring in the winter months from storms and Kona (southerly) winds. Little rain falls in the summer months. Figure 7 shows this temporal difference in rainfall distribution as the monthly percentage increase by months above the median monthly rainfall for June, the driest month, for gages 794 at Waimanalo and 789 at Konahuanui. The altitude and annual median rainfall at the gages are 20 feet and 39 inches, and 3,105 feet and 89 inches, respectively.

\section{EVAPOTRANSPIRATION}

In Hawai it is not uncommon for annual rainfall to range from about 20 inches in dry coastal areas to 250 inches or more in the wet interior mountains. It is also not uncommon for annual pan evaporation to range from less than 20 inches to about 100 inches or more from the wettest to the driest areas. The range in annual rainfall in the study area is from about 25 inches to about 150 inches. The relation of mean monthly pan evaporation to mean monthly rainfall for selected gages having different rainfall in the study area is shown in figure 8 . 


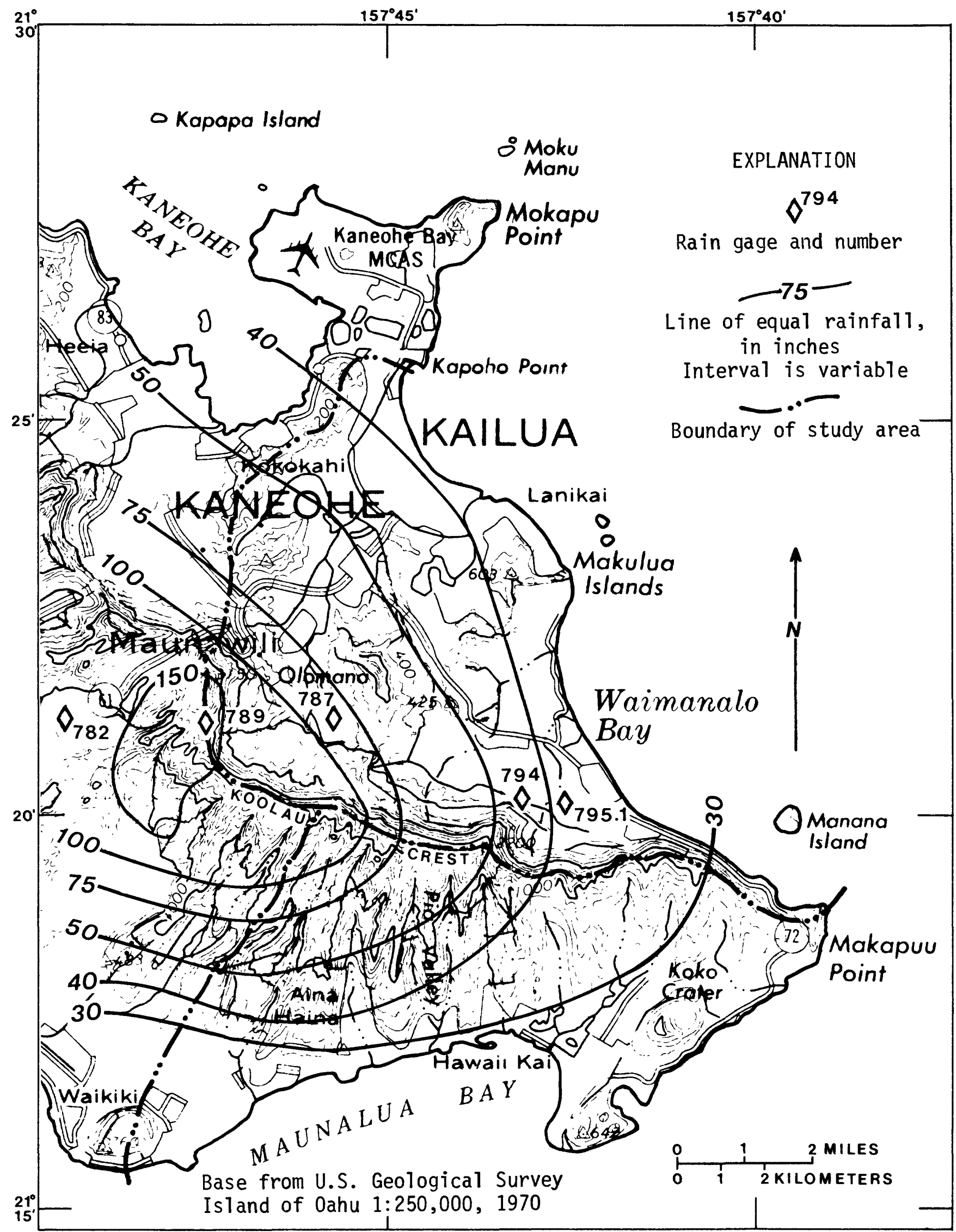

Figure 6. Distribution of mean annual rainfall in southeastern Oahu. (Rainfall data furnished by the Honolulu Board of Water Supply, 1963.) 
Table 2. Distribution of the equivalent volume of annual rainfall between selected lines of equal rainfall

[Data are in millions of gallons per day, except as indicated]

\begin{tabular}{|c|c|c|c|c|c|c|c|c|c|c|}
\hline \multirow[b]{2}{*}{$\begin{array}{l}\text { Mean } \\
\text { annual } \\
\text { rain- } \\
\text { fall } \\
\text { (in.) }\end{array}$} & \multicolumn{4}{|c|}{ Windward } & \multicolumn{4}{|c|}{ Leeward } & \multirow{2}{*}{\multicolumn{2}{|c|}{$\begin{array}{c}\text { Per- } \\
\text { cent- } \\
\text { age } \\
\text { of } \\
\text { al total }\end{array}$}} \\
\hline & $\begin{array}{l}\text { Mauna- } \\
\text { wili } \\
\text { Valley }\end{array}$ & $\begin{array}{c}\text { Waima- } \\
\text { nalo } \\
\text { areaal }\end{array}$ & $\begin{array}{l}\text { Wind- } \\
\text { ward } \\
\text { total }\end{array}$ & $\begin{array}{l}\text { Per- } \\
\text { cent- } \\
\text { age } \\
\text { of } \\
\text { total }\end{array}$ & $\begin{array}{l}\text { Waia- } \\
\text { lae } \\
\text { Nui }\end{array}$ & $\begin{array}{l}\text { Hawa i i } \\
\mathrm{Kai} \text { b/ }\end{array}$ & $\begin{array}{l}\text { Lee- } \\
\text { ward } \\
\text { total }\end{array}$ & $\begin{array}{l}\text { Per- } \\
\text { cent- } \\
\text { age } \\
\text { of } \\
\text { total }\end{array}$ & & \\
\hline$<30$ & 0 & 0.4 & 0.4 & $<1$ & 5.6 & 1.6 & 7.2 & 15 & 7.6 & 6 \\
\hline $30-40$ & 9.0 & 7.6 & 16.6 & 22 & 4.0 & 7.1 & 11.1 & 23 & 27.7 & 22 \\
\hline $40-60$ & 19.1 & 10.8 & 29.9 & 39 & 11.5 & 3.6 & 15.1 & 31 & 45.0 & 36 \\
\hline $60-80$ & 9.1 & 5.1 & 14.2 & 19 & 7.3 & 0.2 & 7.5 & 15 & 21.7 & 17 \\
\hline $80-100$ & 9.5 & 1.4 & 10.9 & 14 & $4 \cdot 3$ & 0 & 4.3 & 9 & 15.2 & 12 \\
\hline$>100$ & 4.5 & 0 & 4.5 & 6 & 3.3 & 0 & 3.3 & 7 & 7.7 & 7 \\
\hline $\begin{array}{l}\text { Total } \\
\text { Grand } \\
\text { total } \\
\text { (rounde }\end{array}$ & 51.2 & 25.3 & 76.5 & 100 & 35.8 & 12.5 & 48.3 & 100 & 124.7 & 100 \\
\hline
\end{tabular}

af Includes Makapuu area.

b/ Excludes areas surrounding Hanauma Bay and Koko Crater. 


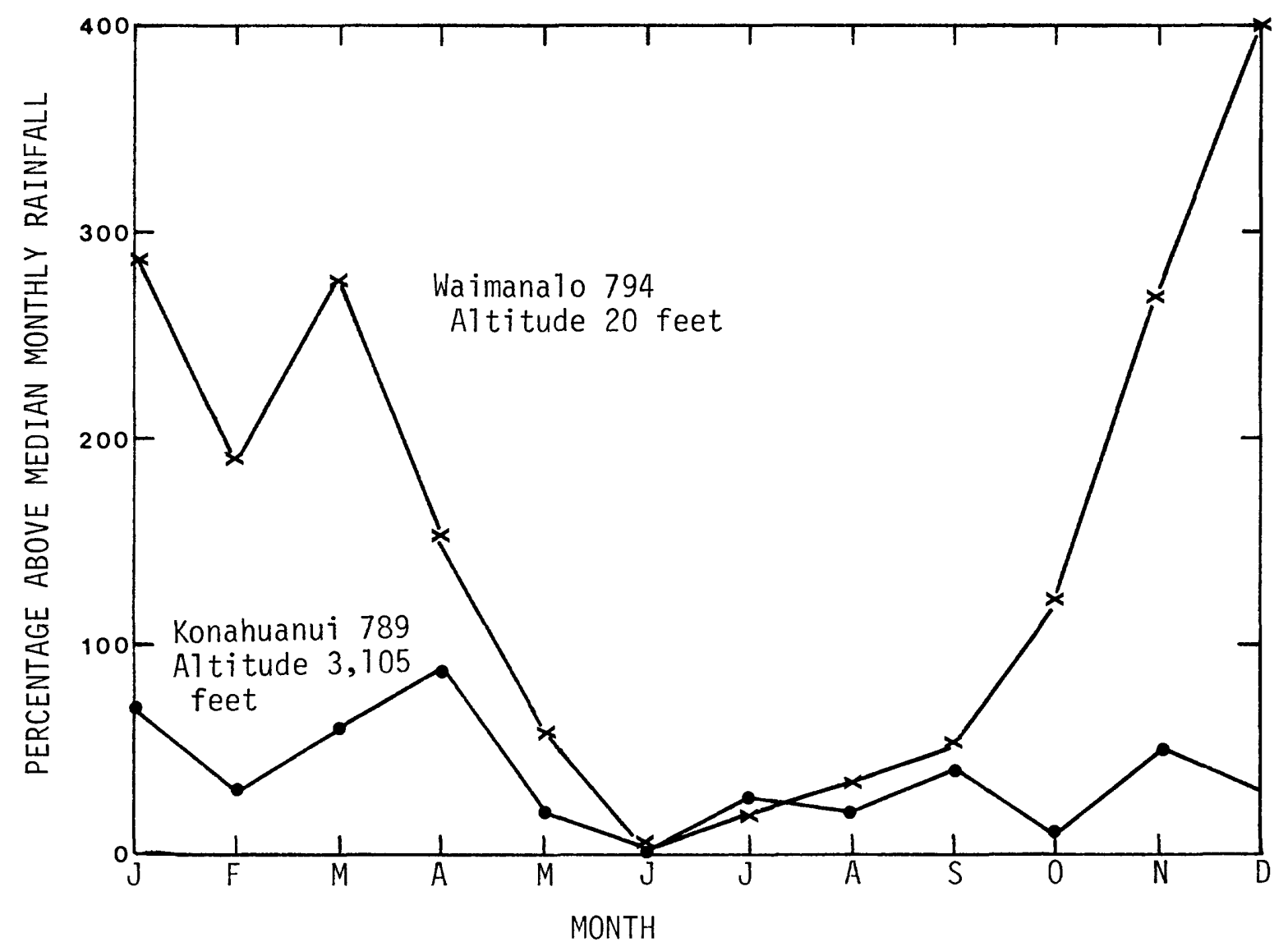

Figure 7. Percentage increase by months above the median June rainfall for gages 794 and 789 for period of record. 

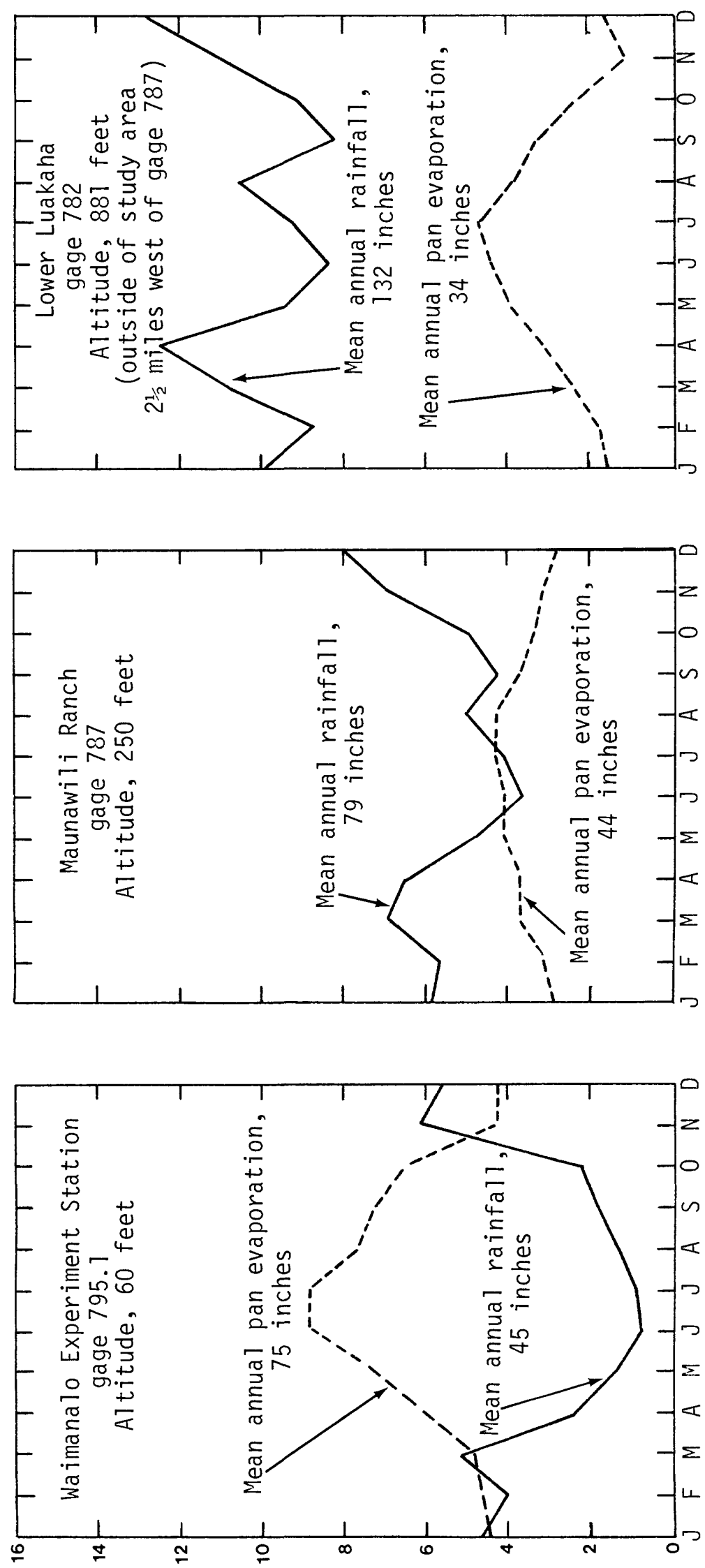

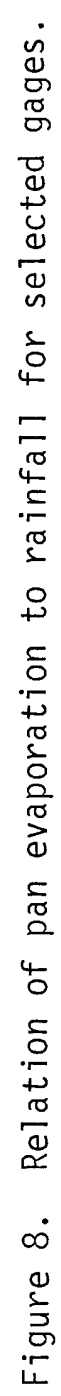

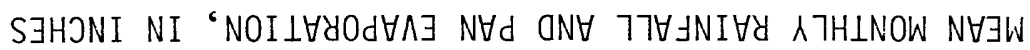


Mink (1962) recognized a relation between rainfall and pan evaporation. Cox (in Campbell and others, 1959) concluded that it was possible to discuss potential evapotranspiration empirically as a function of rainfall. Where water is constantly available to plants, such as in areas where rainfall is high or the water table shallow, evapotranspiration probably approaches the potential of evaporation from a free water surface. Where water is not constantly available to plants, owing to low rainfall or deep water tables, evapotranspiration is far less than potential evaporation.

\section{STREAMS}

Streams in the study area are short, flashy, and have steep gradients. Perennial streamflow to the sea occurs only in Maunawili Valley and in the Waimanalo area. The source of flow in the waimanalo area is mostly return irrigation water with some discharge of shallow ground water from the coastal sediments.

On the leeward slopes, streams are perennial only in their headwaters in the western half of the study area. Perennial flow in the headwaters is maintained by the high rainfall and by the leakage of dike-impounded ground water. Mean annual stream discharge is estimated at $20 \mathrm{Mgal} / \mathrm{d}$ in the windward side and at $15 \mathrm{Mgal} / \mathrm{d}$ in the leeward side. The low flow to sea, expressed as the flow that is equalled or exceeded 90 percent of time $\left(Q_{90}\right)$, is $5 \mathrm{Mgal} / \mathrm{d}$ windward of the Koolau crest and zero leeward of the crest.

\section{GROUND WATER}

Most fresh ground water occurs in lava flows of the Koolau Volcanics that make up the bulk of the rocks in the study area. Ground water is impounded by dikes in the rift zones and floats on saline ground water as lenses of freshwater outside the $r$ ift zones. Small but important bodies of freshwater are perched in volcanic rocks of the Honolulu Group in Maunawili Valley.

Sediments carry some freshwater in deeply buried gravels derived from volcanic rocks in the Waimanalo area. Freshwater occurs in near-shore calcareous sand that overlies a clay horizon in the Waimanalo area. 
Brackish ground-water reservoirs occur in near-shore areas in highly permeable coralline material and fresh lava flows of the Honolulu Group. These reservoirs yield water copiously to production wells and also accept waste water readily from disposal wells.

The principal occurrence of dike-impounded water is in the windward side where dike-free rocks are absent or nearly so. Dike-impounded water in this area is part of a large natural reservoir that extends throughout the riftzone areas. The highest water levels are in the north-central part of the Koolau Range and the lowest at the north and south ends of the Range. Dikeimpounded water also occurs in the leeward area but is generally located far inland and at high altitudes. Basal ground water in dike-free lava flows downgradient of the intruded lava flows is the principal occurrence in the leeward side. Basal water levels are highest in the western part and lowest in the eastern end on the leeward side.

Mean sea level is the datum for ground-water levels and heads in this report, unless specified otherwise.

\section{WATER RESOURCES IN SELECTED SUBAREAS}

\section{Windward (Northside) of Koolau Crest}

\section{Maunawili Valley}

\section{Geologic setting}

Maunawili Valley, about 18 square miles in area, drains into Kailua Bay (fig. 9). Two prominent volcanic spurs that extend northeastward from the main Koolau crest separate the valley from the Waimanalo area to the southeast and the Kaneohe area to the northwest. The area includes much of the caldera, which is centered in and near Kawainui Swamp at the junction of the northwest, southeast, and southwest (Kaau) rifts. The strike of the dikes is predominantly N. $55^{\circ} \mathrm{W}$. in the nor thwest $r$ ift, N. $75^{\circ} \mathrm{W}$. in the southeast $r i f t$, and $\mathrm{N}$. $30^{\circ} \mathrm{E}$. in the southwest rift. Intersecting of dikes is common in the caldera but its frequency decreases significantly away from it. 
EXPLANATION

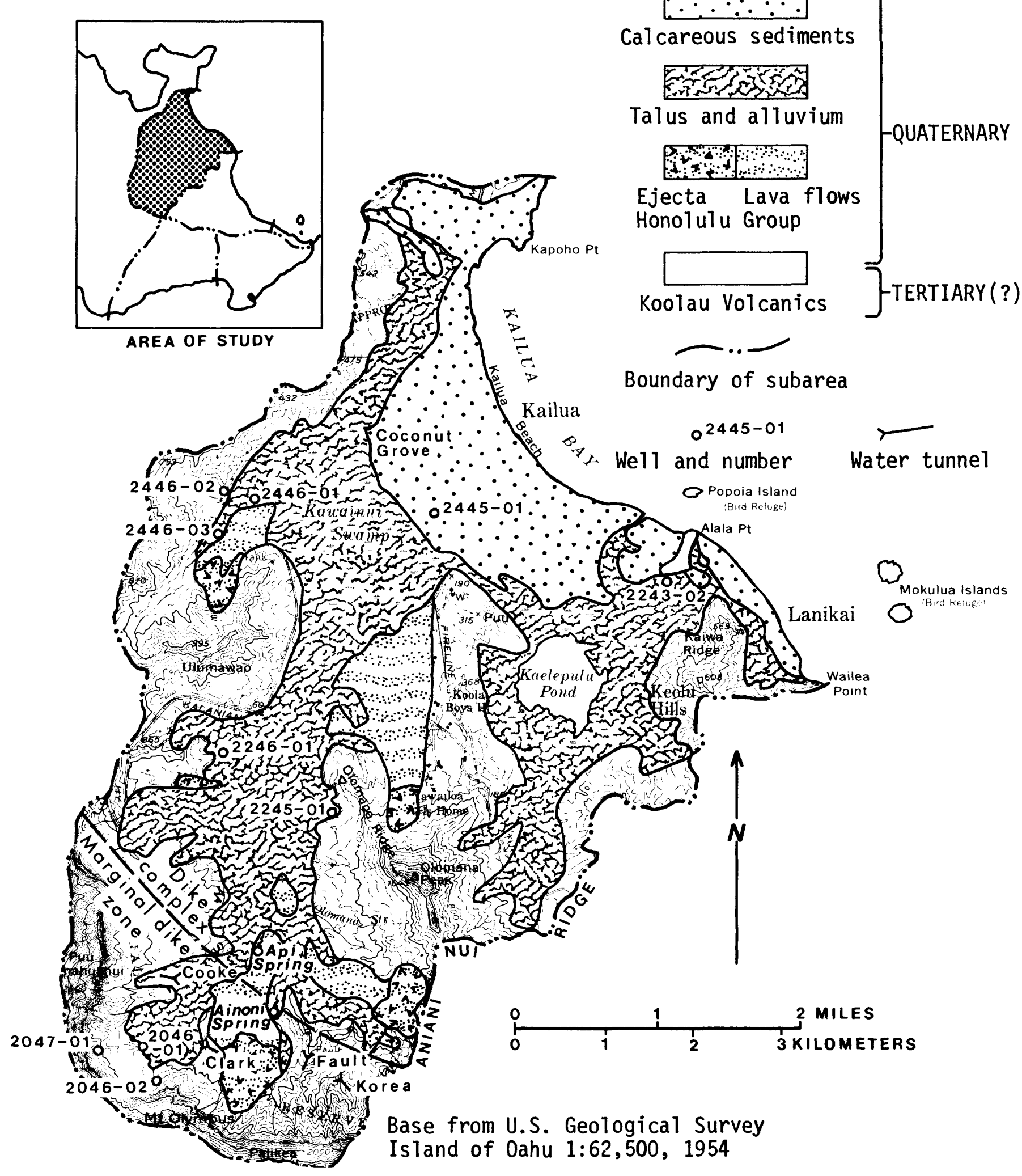

Figure 9. Geologic map of Maunawili Valley showing location of wells and tunnels (geology from Stearns, 1939). 
Demarcation between the dike complex and the marginal dike zone is shown in figure 9. The marginal dike zone includes the areas of numerous springs and seeps, of which the larger were developed using tunnels as collection and conveyance structures. Significant springs and seeps are generally absent in the dike complex.

Lava flows, extruded outside the caldera, make up the present Koolau crest area and flows that were extruded within the caldera make up the ridges that extend northward and seaward from the present Koolau crest. Pyroclastic rocks and lava flows of the Honolulu Group are scattered throughout the valley. Well-consolidated older alluvium forms an apron at the base of cliffs and underlies the upper part of deep stream valleys. Younger, less consolidated alluvium underlies the lower parts of the valleys.

Coastal-plain sediments in Maunawili Valley consist of very fine to coarse silty calcareous sand, dune sand, silt, and sandy clay; all of which are locally mixed with coral and coral fragments (Swain and Huxel, 1971). The landward section of the sediments in the northern part is covered by Kawainui Swamp, the top layer of which is a nearly impermeable mixture of clay and organic matter. The Swamp, el sewhere, is underlain predominantly by clay with some sand. Sediments are less extensive in the south part of the valley.

\section{Streams}

Maunawili Valley is drained mainly by Maunawili and Kahanaiki Streams and their tributaries. Most of the valley drains into Kawainui Swamp except a small area in the southern part that drains into Kaelepulu Pond. The low flow of Maunawili and Kahanaiki Streams represents discharge of dike-impounded and perched water reservoirs and thus increases downstream to a maximum at Kawainui Swamp. All the low flow of Maunawili Stream above an altitude of about 425 feet is diverted and transported to the Waimanalo area. 
The average flow of Maunawili Stream that drains into Kawainui Swamp is about $18 \mathrm{ft}^{3} / \mathrm{s}(11.6 \mathrm{Mgal} / \mathrm{d})$ and its low flow, expressed as the flow equaled or exceeded 90 percent of the time $\left(Q_{90}\right)$, is $4 \mathrm{ft}^{3} / \mathrm{s}(2.6 \mathrm{Mgal} / \mathrm{d})$. The figures are based on continuous record from January 1967 to September 1971, a period when rainfall was near normal, and on periodic measurements during 1922 and the periods 1956-62, and 1965-80. Average flow of Kahanaiki Stream is est imated at $5 \mathrm{ft}^{3} / \mathrm{s}(3.2 \mathrm{Mgal} / \mathrm{d})$ and its low $\mathrm{flow}_{\text {at }} 0.6 \mathrm{ft}^{3} / \mathrm{s}(0.4 \mathrm{Mgal} / \mathrm{d})$. The estimates for Kahanaiki Stream were based on periodic measurements and by correlation with nearby streams in the Kaneohe area to the north.

A systematic measurement of the low flow in Maunawili Valley was made by the U.S. Geological Survey in July 1959, during a prolonged period of low rainfall (fig. 10). The Honolulu Board of Water Supply made a similar set of measurements of the flow being diverted into Maunawili Ditch in November 1960 (Lee, 1960). The Board's measurements were comparable to those of the Geological Survey. Based on these measurements, figure 11 was prepared showing the low flows at selected altitudes in the valley as percentages of the total flow. As shown in the figure, about 60 percent of the flow is discharged above an altitude of 400 feet. Below this altitude, the rate of increase in the low-flow discharge is significantly reduced.

This change in the rate of discharge which occurs at about the 400 -foot level roughly coincides with the boundary between the marginal dike zone on the upstream side and the dike complex on the downstream side. Figure 11 shows a possible water-table gradient across the Koolau crest and also the percentage gain in low flow with decreasing altitude.

\section{Ground water}

Dike-impounded water.--Dike-impounded water is the most important source of ground water in Maunawili Valley. It occurs in most areas underlain by volcanic rocks. In the interior mountains, the top of dike-impounded reservoirs extends to an altitude of at least 900 feet. Below an altitude of 500 feet and in all the low-lying areas, the top of the reservoirs extend up to or near the ground surface. Dike-impounded water is generally unconfined in the interior of high mountains and is confined, to some degree, in low-lying areas under a mantle of alluvium, volcanic rocks of the Honolulu Group, or highly weathered rocks. 


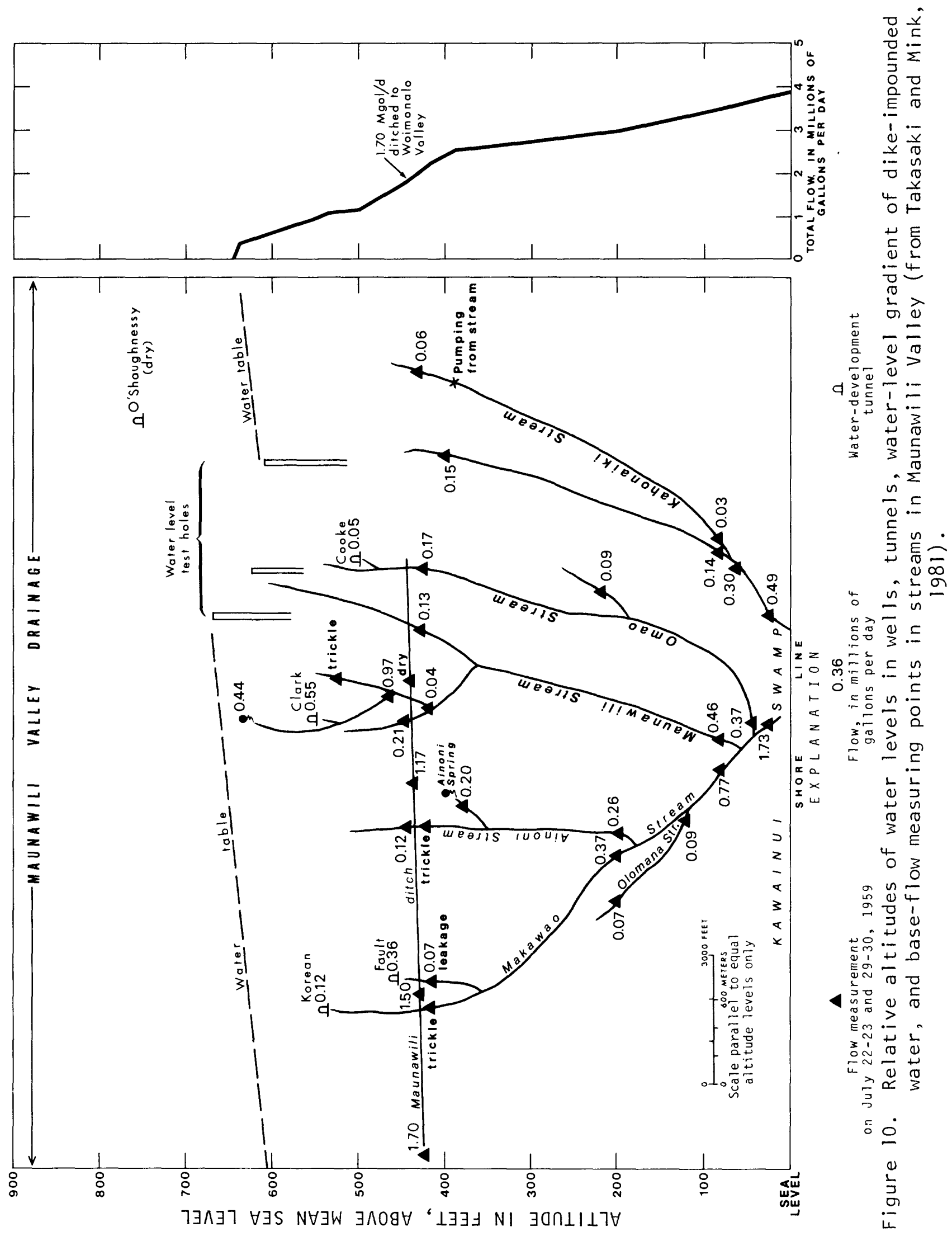




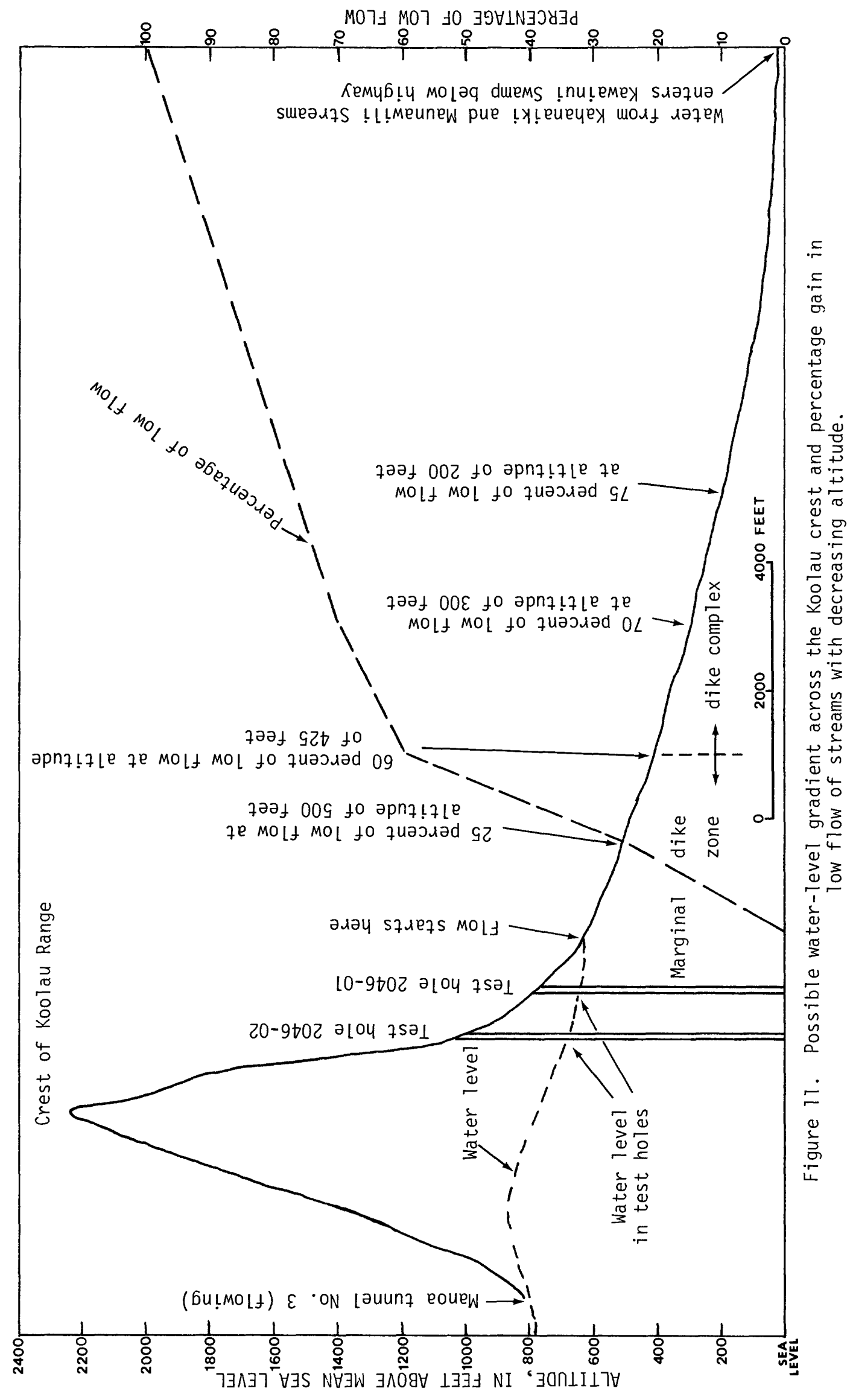


Dike-impounded water levels in the Koolau Range stand about 100 feet higher in the central and eastern part of Maunawili Valley where northeasttrending dikes of the Kaau $r i f t$ intersect northwest-trending dikes of the main fissure zone than in the adjacent westernmost part, away from the Kaau rift (fig. 10). The high water levels continue into the Waimanalo area as do the dikes of the Kaau rift. The higher water levels either reflect slower drainage from more compartmented dike impoundments or are part of a higher standing water body in the Kaau $r$ ift zone in the leeward side (southside) of the Koolau rift.

Ground water loses its identity as being dike-impounded in and near the caldera where the dikes, as well as the rocks they intrude, are highly mineralized and deeply weathered. Any contrast in permeability between the dikes and the intruded rocks becomes nonexistent and water-level gradients no longer are steplike, as in dike-impounded reservoirs, but tend to follow the general contour of the land surface.

Perched water.--Small reservoirs of ground water perched above dikeimpounded reservoirs are common. Most are small and not important as sources of developable water. Exceptions are perched reservoirs that occur in volcanic rocks of the Honolulu Group where they overlie alluvium or under rocks of the Honolulu Group where they overlie a lava-flow surface of the Koolau Volcanics. The reservoirs occur in Honolulu rocks where they overlie alluvium and occur under Honolulu rocks where they are the confining unit and overlie more permeable Koolau rocks. Ainoni and Api Springs are larger springs that discharge at the edges or toes of Honolulu rocks in upper Maunawili Valley.

Stearns and Vaksvik (1935, p. 440) list spring flow of about 700,000 gal/d originating from the Honolulu volcanic rocks in Maunawili Valley. They were uncertain of the origin of $300,000 \mathrm{gal} / \mathrm{d}$ of this quantity. Of the remaining 400,000 gal/d, they concluded that about 300,000 gal/d issues from Ainoni Springs. 
Basal water.--Basal water occurs in marine sediments and in other rocks abutting the sea. The chloride concentration of water in the basal reservoirs generally is more than $500 \mathrm{mg} / \mathrm{L}$, and increases significantly when water is pumped from wells at high rates. In a study to determine the principal cause of flooding in the Coconut Grove area underlain by calcareous sand, Swain and Huxel (1971) made periodic water-level measurements in 25 shallow test borings (fig. 12). Owing to the rapid rise in water level after a rain and the slow decline following it, they concluded that the permeability of the sand is low. The Coconut Grove area lies seaward of the Kawainui Swamp and ground water underlying the area is not recharged by the Swamp instead discharges into the Swamp. Well 2445-01, drilled in the late 1930's to a depth of 177 feet in the same area, penetrated beach sand, coral, and calcareous mud. The water was reportedly too salty to use, hence the well was abandoned. Two wells, 2343-01 and -02, drilled in the southern part of the valley for irrigation of a golf links were also found too salty for use.

Water-level fluctuations.--The magnitude of water-level fluctuations in wells tapping rocks in the marginal dike zone, dike complex, and calcareous sediments is shown in figure 13 for a 10-year period from 1953 to 1962 .

Past and potential development.--The earliest development of ground water consisted of simple diversion of springs or spring-fed streams. Tunneling, in hopes of increasing flow at the site of the larger springs in upper Maunawili Valley followed, the first in 1900 and the rest in the early 1920's. The tunnels are open and free-flowing and their flows are diverted to Maunawili Ditch and transported to the Waimanalo area.

The first well (2446-01) in the low-lying area was reportedly drilled in 1892 for watering cattle. Wells drilled in the early 1940's or before include 2245-01, -02, and $-03,2343-01$, and 2445-01. The combined yield of wells 2245-01, -02 , and -03 , which were drilled in the dike complex in highly weathered rocks, was less than $100 \mathrm{gal} / \mathrm{min}$. These wells, which supplied a State institution, have not been used for several years. Wells 2343-01 and 2445-01 were drilled in calcareous material where they tapped water too salty to use. The location of drilled wells is shown in figure 9. 


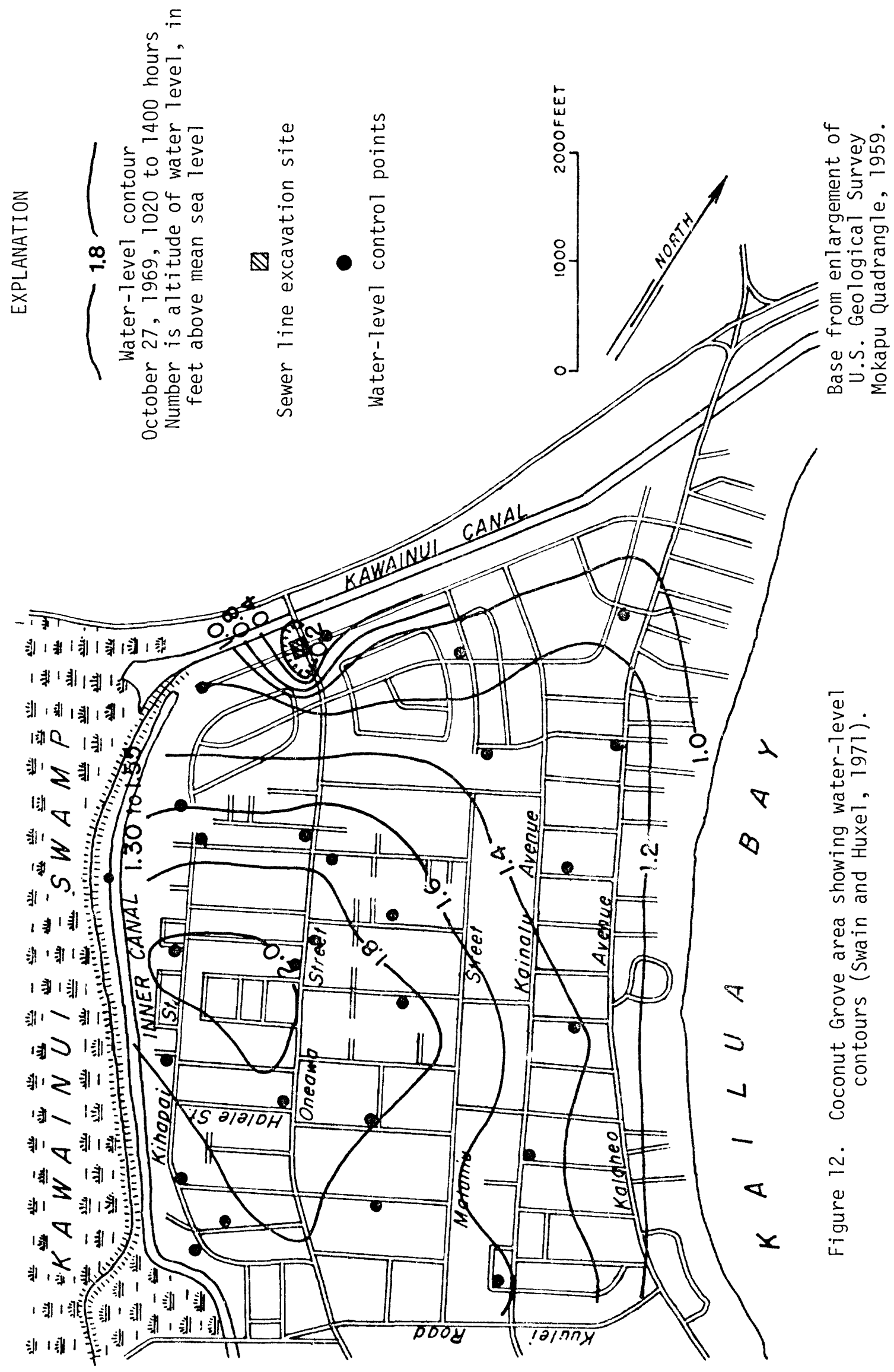




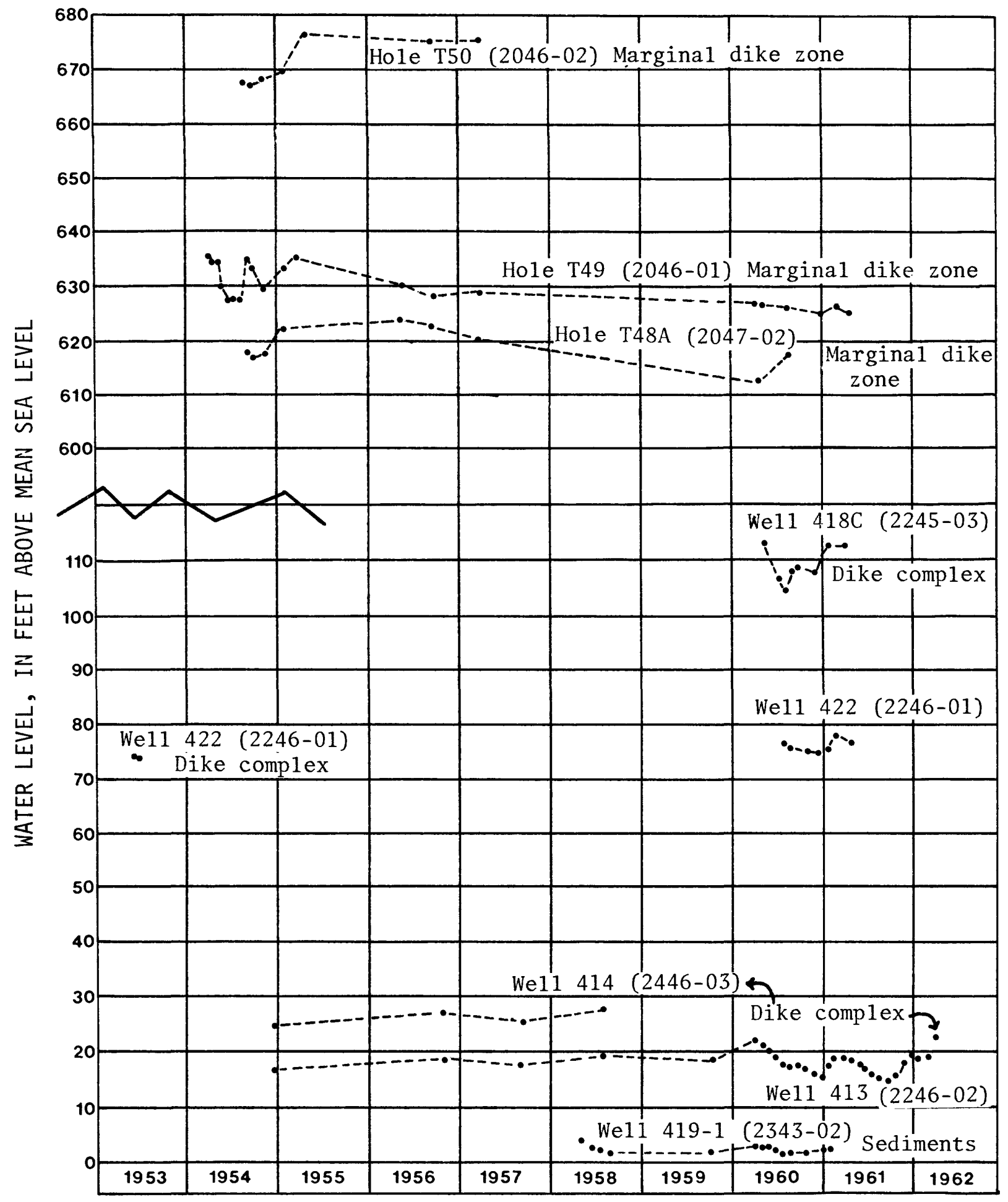

Figure 13. Water-level fluctuations of Maunawili Valley wells tapping rocks in the dike complex, marginal dike zone, and calcareous sediments. 
Two wells were drilled in 1944 near Kawainui Swamp for truck-farm irrigation. They yielded about $10 \mathrm{gal} / \mathrm{min}$ and were active for about 10 years before they were abandoned. The latest production well was drilled in 1953 at an altitude of 92 feet. It was drilled in the dike complex and yielded 300 $\mathrm{gal} / \mathrm{min}$ at a drawdown of $210 \mathrm{feet}$. The well was used as a municipal source of supply only for 2 years, in 1953 and 1954, when it supplied 8 and 5 million gallons of water, respectively. Except for three wells recently drilled for the disposal of household sewage, all wells previously drilled have been sealed, abandoned, or are inactive. The present development consists only of the free-flowing tunnels above the Maunawili Ditch which transports their flows to the Waimanalo area. Data on wells and tunnels in Maunawili Valley are given in table 3 .

Ground-water underflow to sea is probably small owing to highly mineralized and weathered rocks at depth in the low-lying areas. Ground water is thus forced up to the surface where it discharges into stream channels and marshes. The discharge is more profuse in the more permeable rocks of the marginal dike zone above an altitude of 400 feet than in the the low permeable rocks of the dike complex generally below this altitude. Figure 11, which shows low flow in the valley as percentages of the total flow, illustrates the marked difference in discharge above and below this altitude.

The current development scheme utilizes only the free-flow equilibrium discharge from tunnels above an altitude of 400 feet. This flow cannot be increased or decreased and is generally higher than the demand in the rainier winter months and less than the demand in the drier summer months. This can be compared to operating from full or nearly full storage with overflow from storage being the only usable operating flow. Underground storage of ground water is large in Maunawili Valley and appears to be easily developable in the marginal dike zone and much less so in tighter rocks of the dike complex. 
Table 3. Tunnels and wells in Maunawili Valley

\begin{tabular}{|c|c|c|c|c|c|c|c|c|c|c|c|c|c|c|}
\hline$\frac{\text { Well }}{\text { New }}$ & $\frac{\text { No. }}{\text { old }}$ & $\begin{array}{l}\text { Diam- } \\
\text { eter } \\
\text { (in.) }\end{array}$ & $\begin{array}{l}\text { Alti- } \\
\text { tude } \\
(f t)\end{array}$ & $\begin{array}{l}\text { Depth } \\
(f t)\end{array}$ & $\begin{array}{l}\text { Ca- } \\
\text { sing } \\
(f t)\end{array}$ & $\begin{array}{l}\text { Aqui- } \\
\text { fer }\end{array}$ & $\begin{array}{c}\text { Year } \\
\text { drilled }\end{array}$ & $\frac{\text { Head }}{\text { High }}$ & $\frac{f t}{\text { Low }}$ & $\begin{array}{c}\text { Chlor } \\
\text { cone } \\
\text { tra } \\
\text { (mg) } \\
\text { High }\end{array}$ & $\begin{array}{l}\text { ride } \\
\text { cen- } \\
\text { tion } \\
\text { (L) } \\
\text { Low }\end{array}$ & Use [ & $\begin{array}{c}\text { Specific } \\
\text { capacity } \\
{[(\mathrm{gal} / \mathrm{min}) / \mathrm{ft}}\end{array}$ & Remarks \\
\hline $2045-01$ & --- & -- & $-\cdots$ & -- & --- & -- & 1920 & $\cdots$ & --- & -- & -- & $\begin{array}{l}\text { Irriga- } \\
\text { tion }\end{array}$ & $\cdots$ & Fault tunnel. \\
\hline $2045-02$ & $-\cdots$ & -- & $-\cdots$ & -- & --- & -- & 1923 & $\ldots$ & -- & -. & -- & do. & --- & Korean tunnel. \\
\hline $2046-01$ & T49 & -- & 777 & -- & -- & -- & 1954 & 636 & 625 & -- & -- & $\begin{array}{l}\text { Obser- } \\
\text { vation }\end{array}$ & $\cdots$ & $\begin{array}{l}\text { Exploration hole in up- } \\
\text { per Maunawili Valley. }\end{array}$ \\
\hline $2046-02$ & T50 & -- & 1,008 & -- &.-- & -- & do. & 676 & 667 & -.- & -- & do. & $\ldots$ & Do. \\
\hline $2047-01$ & $T 48$ & -- & 1,272 & -- & -- & -- & 1953 & 1,170 & 1,013 & -- & -- & do. & $\cdots$ & Do. \\
\hline $2047-02$ & $T 48 \mathrm{~A}$ & -- & 1,272 & -- & --- & -- & 1954 & 624 & 613 & $\ldots$ & -- & do. & $\ldots$ & Do. \\
\hline $2146-01$ & $\cdots$ & -- & $\cdots$ & $\cdots$ & -- & $\cdots$ & 1926 & $\cdots$ & $-\cdots$ & $\cdots$ & -- & & $-\cdots$ & Cooke tunnel. \\
\hline $2146-02$ & --- & -- & $\cdots$ & -- & $\cdots$ & $\cdots$ & do. & $\cdots$ & $\cdots$ & $\cdots$ & -- & & $\cdots$ & Ainoni tunnel. \\
\hline $2147-01$ & $\cdots$ & -- & $\cdots$ & -- & $\cdots$ & -- & 1893 & $\cdots$ & $\cdots$ & $\cdots$ & -- & $\begin{array}{l}\text { Aban- } \\
\text { doned }\end{array}$ & $\cdots$ & O'Shaunessy tunnel. \\
\hline $2245-01$ & $418 \mathrm{~A}$ & 6 & 107 & 135 & 129 & -- & 1940 & 119 & -- & 30 & -- & Sealed & $-\cdots$ & $\begin{array}{l}\text { Well flowed at } 22 \mathrm{gal} / \\
\text { min at } 35-\mathrm{ft} \text { depth. }\end{array}$ \\
\hline $2245-02$ & $418 B$ & 6 & 107 & 200 & 136 & Lava & do. & $\cdots$ & -- & 46 & 31 & None & $\cdots$ & $\begin{aligned} \text { Log: } & 0-75 \mathrm{ft} \text { sediment, } \\
& 75-192 \mathrm{ft} \text { weathered } \\
& \text { lava; yield } 60 \\
& \text { gal/min. }\end{aligned}$ \\
\hline $2245-03$ & $418 \mathrm{C}$ & 8 & 117 & 260 & 155 & do. & 1948 & 116 & 103 & 28 & 21 & do. & $\cdots$ & \\
\hline $2246-01$ & 422 & 12 & 92 & 349 & 265 & do. & 1953 & 78 & 74 & 30 & -- & Sealed & 1.4 & $\begin{array}{l}\text { Pump } 300 \mathrm{gal} / \mathrm{min} \text {, draw- } \\
\text { down } 210 \mathrm{ft} \text {. }\end{array}$ \\
\hline $2343-01$ & 419 & -- & $-\cdots$ & 135 &.-- & --- & -- & $\ldots$ & -- & 500 & -- & & & \\
\hline $2343-02$ & $419-1$ & -- & --- & --- &.- & -- & 1958 & 2.5 & 1 & 7800 & -- & $\begin{array}{l}\text { Aban- } \\
\text { doned }\end{array}$ & $\ldots$ & $\begin{array}{l}\text { Chloride concentration, } \\
728 \mathrm{mg} / \mathrm{L} \text { at } 83 \mathrm{ft} \\
1050 \mathrm{mg} / \mathrm{L} \text { at } 120 \mathrm{ft}, \\
7000 \mathrm{mg} / \mathrm{L} \text { at } 138 \mathrm{ft}, \\
7870 \mathrm{mg} / \mathrm{L} \text { at } 199 \mathrm{ft} \text {. }\end{array}$ \\
\hline $2343-03$ & --- & 5 & 78 & 301 & -- & --- & 1972 & $\cdots-$ & $\cdots$ & 250 & -- & $\begin{array}{l}\text { Dis- } \\
\text { posal }\end{array}$ & $\cdots$ & Log: Lava; disposal well. \\
\hline $2343-04$ & $\cdots$ & 6 & 4 & 52 & 19 & -- & do. & $\cdots$ & $-\cdots$ & -.. & -- & do. & $-\cdots$ & Log: Marine sediment. \\
\hline $2343-05$ & $\cdots$ & 4 & $\cdots$ & 90 & 48 & $\cdots$ & do. & $\cdots$ & $\cdots$ & $-\cdots$ & -- & do. & $\cdots$ & $\begin{aligned} \text { Log: } & 0-27 \mathrm{ft} \text { sediment, } \\
& 27-90 \mathrm{ft} \text { weathered } \\
& \text { lava; percolate } 1 \\
& \text { gal } / \mathrm{min} \text { per } 2-1 / 2 \mathrm{~min} .\end{aligned}$ \\
\hline $2445-01$ & 417 & -- & $\cdots-$ & 177 & -- & -.- & --- & 22 & 14 & 64 & 44 & $\begin{array}{l}\text { Aban- } \\
\text { doned }\end{array}$ & $-\cdots$ & $\begin{aligned} \text { Log: Marine sediment; } \\
\text { salty. }\end{aligned}$ \\
\hline $2446-01$ & 415 & -- & $-\cdots$ & -- & --- & -- & --- & $-\cdots$ & -- & -- & -- & do. & --- & Drilled 1892. \\
\hline $2446-02$ & 413 & 6 & 29 & 108 & 67 & $\cdots$ & 1944 & 22 & 14 & 64 & 44 & do. & $-\cdots$ & $\begin{aligned} \text { Log: } & 0-50 \mathrm{ft} \text { sediment, } \\
& 50-108 \mathrm{ft} \text { weathered } \\
& \text { lava. }\end{aligned}$ \\
\hline $2446-03$ & 414 & 6 & 47 & 184 & $1 / 163$ & $\cdots$ & do. & 28 & 25 & 46 & 39 & do. & $\cdots$ & $\begin{aligned} \text { Log: } & \text { Weathered rock; } \\
& \text { slotted } 128 \mathrm{ft} .\end{aligned}$ \\
\hline
\end{tabular}

1/ See remarks. 
The low flow $\left(Q_{90}\right)$ of Maunawili Valley, including the discharge of tunnels, probably is between 4 and $4.5 \mathrm{Mgal} / \mathrm{d}$. This is the maximum dependable flow that is currently available under the existing development scheme that utilizes the discharge of the free-flowing tunnels and the remaining low flow of streams. This flow can be increased significantly for part of the year if storage is depleted by pumping wells when demand is high. Because of the resulting lowered water levels, overflow will be small or absent when demand is low. Storage is thus restored during the low-demand, low water-level period at a rate no less than 4 to $4.5 \mathrm{Mgal} / \mathrm{d}$. Owing to a probable reduction in the rate of evapotranspiration, the recharge rate may likely be higher.

Deep wells drilled in the marginal dike zone will probably be the optimum method of dewatering and increasing flow during the high demand period. The existing tunnels will be affected; some will cease to flow during the dewatering period. Wells drilled in the dike complex can be dependable sources of small local supplies. Owing to the low permeability of the rocks in the dike complex, dewatering will be localized.

Data available for the existing tunnels do not appear to favor the use of bulkheads as a means of manipulating storage.

\section{Waimanalo Area}

\section{Geologic setting}

The Waimanalo area, about 11 square miles, includes the southeast part of windward (northside) Oahu (fig. 1). Aniani Ridge that extends northeastward from the Koolau Range separates the area from Maunawili Valley to the northwest. A precipitous volcanic cliff starting from the Koolau crest, the area's southern boundary, abruptly slopes into a gent le alluvial upland area. A sandy low-lying coastal plain aprons the entire shore. 
The steep interior mountainous areas are composed mostly of southwarddipping thin-bedded lava flows of the Koolau Volcanics. The lavas are dikeintruded, mostly by northerly trending dikes and sparsely by northwesttrending dikes (fig. 3 ). The area near the crest is in the marginal dike zone. North of the high cliffs, dikes become numerous, especially in outcrops in Aniani Ridge, as in a dike complex. The line separating the marginal dike zone and the dike complex has been placed near the base of the cliffs. It represents a smooth continuation of such a line that extends into the Kaneohe area to the northwest. Most of the dikes in the dike complex are buried under a mant le of alluvium.

Dikes in the main fissure zone generally strike about $N .75^{\circ} \mathrm{W}$. in the west part and nearly east-west in the east part (fig. 3). Dikes have been mapped on Olomana, in Aniani Ridge, in road cuts, and in the transmission tunnels between Maunawili Valley and Waimanalo but many other dikes probably extend below the alluvial cover in the dike complex. Dikes in the minor $r$ ift zones generally strike north or northeast or nearly at right angles to the crest. Some of these dikes continue and crop out in the main fissure zone in Aniani Ridge.

The upper part of the sedimentary section underlying the coastal plain is composed of reef limestone, calcareous clay, dune and beach sand, and terrigenous deposits. Lum and Stearns (1970) correlated stratigraphic and lithologic information from eight core holes and showed that the depositional environments that produced these sediments were attributable to four major fallings and four major risings of sea level during major glacial and interglacial periods in Pleistocene time. A generalized geologic section of the sediments discussed by Lum and Stearns (1970) is shown in figure 14 . The coastal plain comprises about 3 of the 11 square miles in the Waimanalo area. Relation of the sediments to volcanic rocks and older terrigenous deposits is shown in a generalized geologic section (fig. 14) and geologic map (fig. 15). Rocks designated by parentheses in figure 14 can be correlated with the rocks designated by parentheses in figure 15 . 


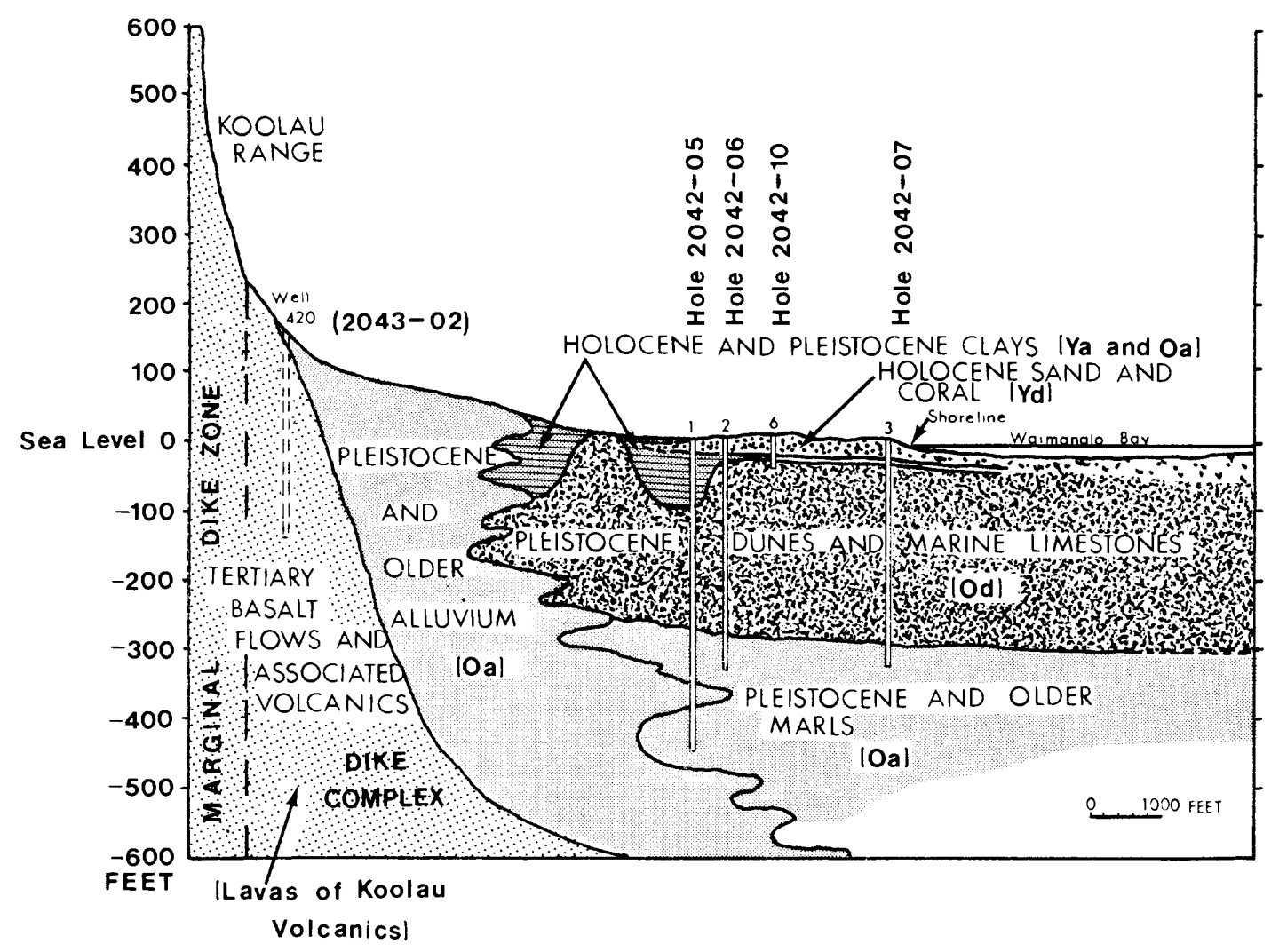

EXPLANATION

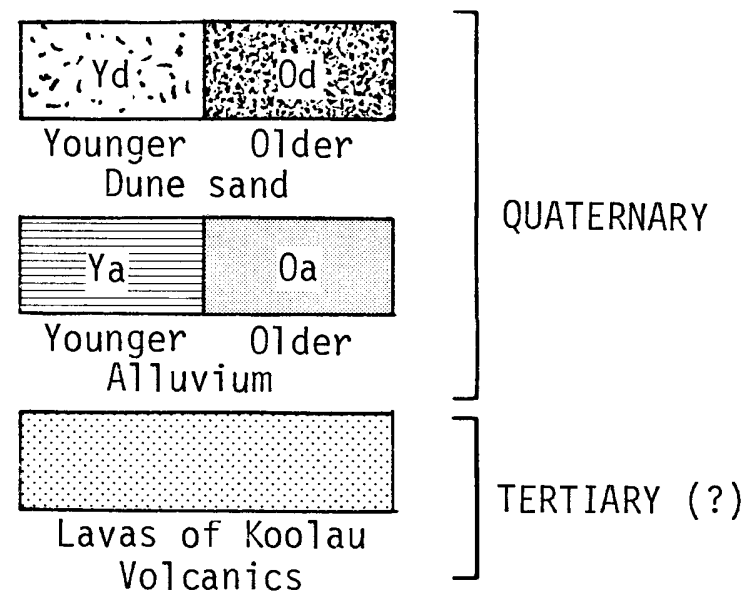

Figure 14. Generalized geologic section of coastal plain in Waimanalo area (modified from Lum and Stearns, 1970). 


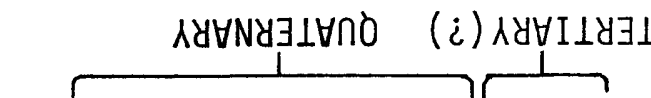

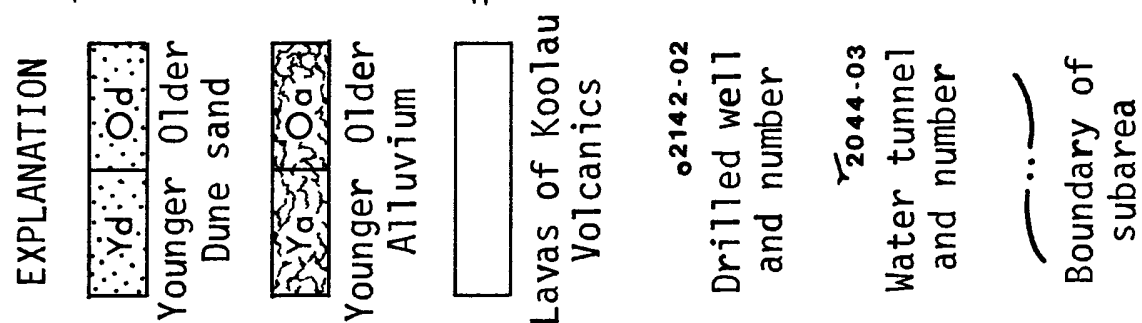

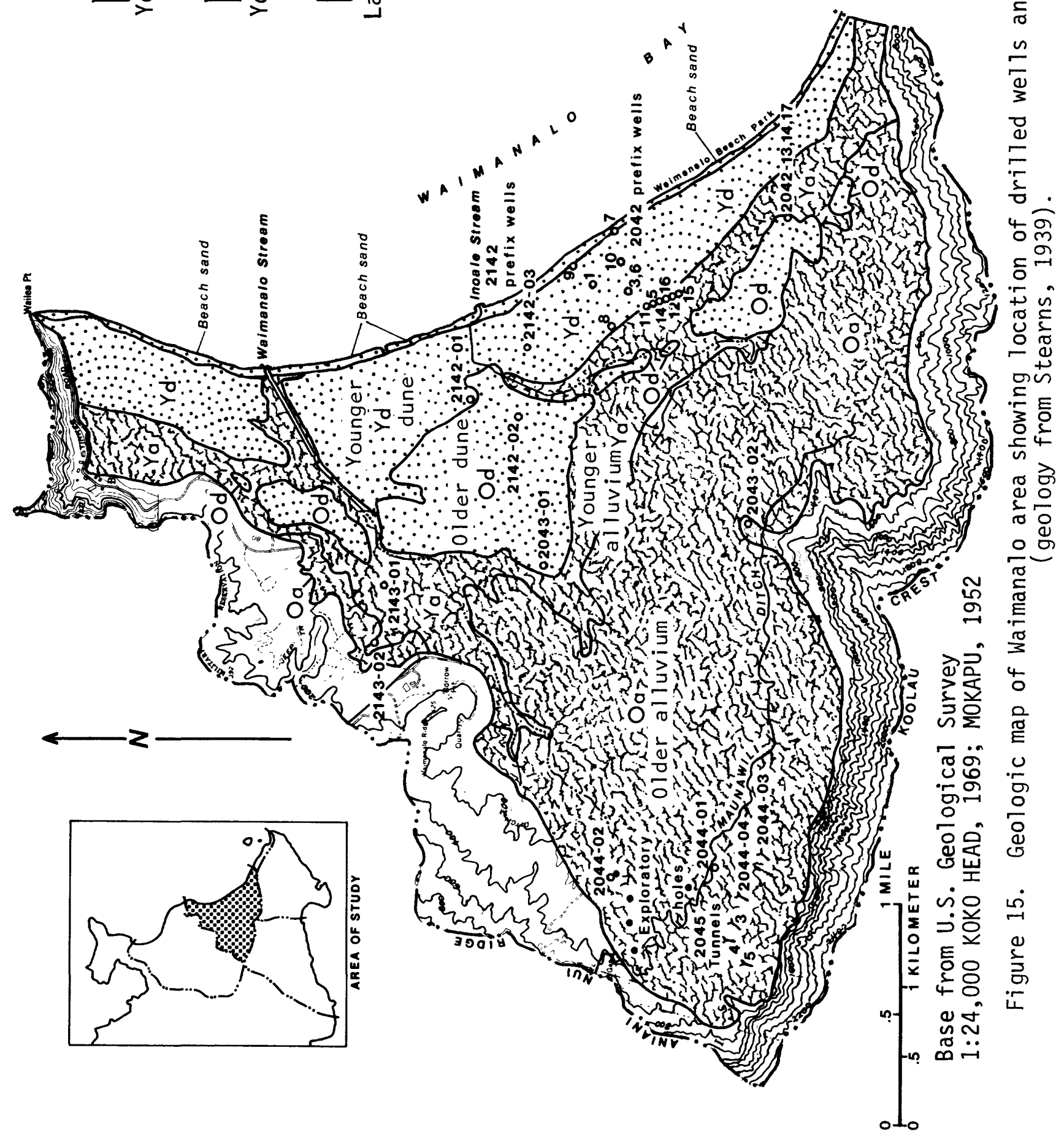


The Waimanalo area is drained mainly by two stream systems, Waimanalo Stream north of Waimanalo town and Inoaole Stream south of the town. Waimanalo Stream, the only perennial stream, is gaged at an altitude of about 19 feet where it crosses the highway and includes a drainage area of 2.16 square miles. A continuous record of streamflow is available for the period 1967 to 1970 after which the gage was converted to a crest-stage partialrecord gage. Average flow of Waimanalo Stream at the gage is $4.5 \mathrm{ft}^{3} / \mathrm{s}(2.9$ $\mathrm{Mgal} / \mathrm{d})$ and its low flow is $0.5 \mathrm{ft}^{3} / \mathrm{s}(0.3 \mathrm{Mgal} / \mathrm{d})$. The perennial flow of the stream at the gage is probably mostly return irrigation flow. A crest-gage has been in service in Inoaole Stream since 1958. It has a drainage area of $1.21 \mathrm{mi}^{2}$ but the stream is dry more than 75 percent of the time.

A systematic measurement of the low flow in the area was made on July 31 , 1959, during a prolonged period of low rainfall. The measured flow, including tunnel flow, was about 1 Mgal/d above the level of Maunawili Ditch and about $0.70 \mathrm{Mgal} / \mathrm{d}$ below the ditch (fig. 16).

Ground water

Dike-impounded water.--Ground water is impounded by dikes in all the volcanic aquifers in the Waimanalo area. It is the most important source of ground water, especially where it occurs in the marginal dike zone where the rocks are more permeable than in the dike complex. The high water-level anomaly in Maunawili Valley caused by the intersecting of northwest- and northeast-striking dikes continues into the Waimanalo area where it drops at least 100 feet, about 4,000 feet west of the area's western boundary (fig. 16). Most surface discharge of dike-impounded water occurs in the marginal dike zone. Owing to the thick wedge and mantle of alluvium over much of the dike complex, surface discharge of dike-impounded water is negligible.

Perched water.--Ground water is probably perched in numerous small. reservoirs above dike-impounded water. None of the reservoirs, however, shows any discharge at the surface. 


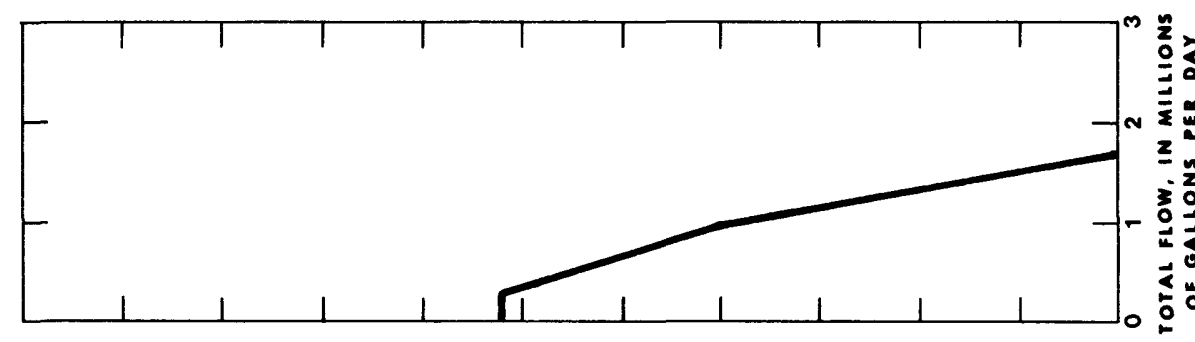

밈

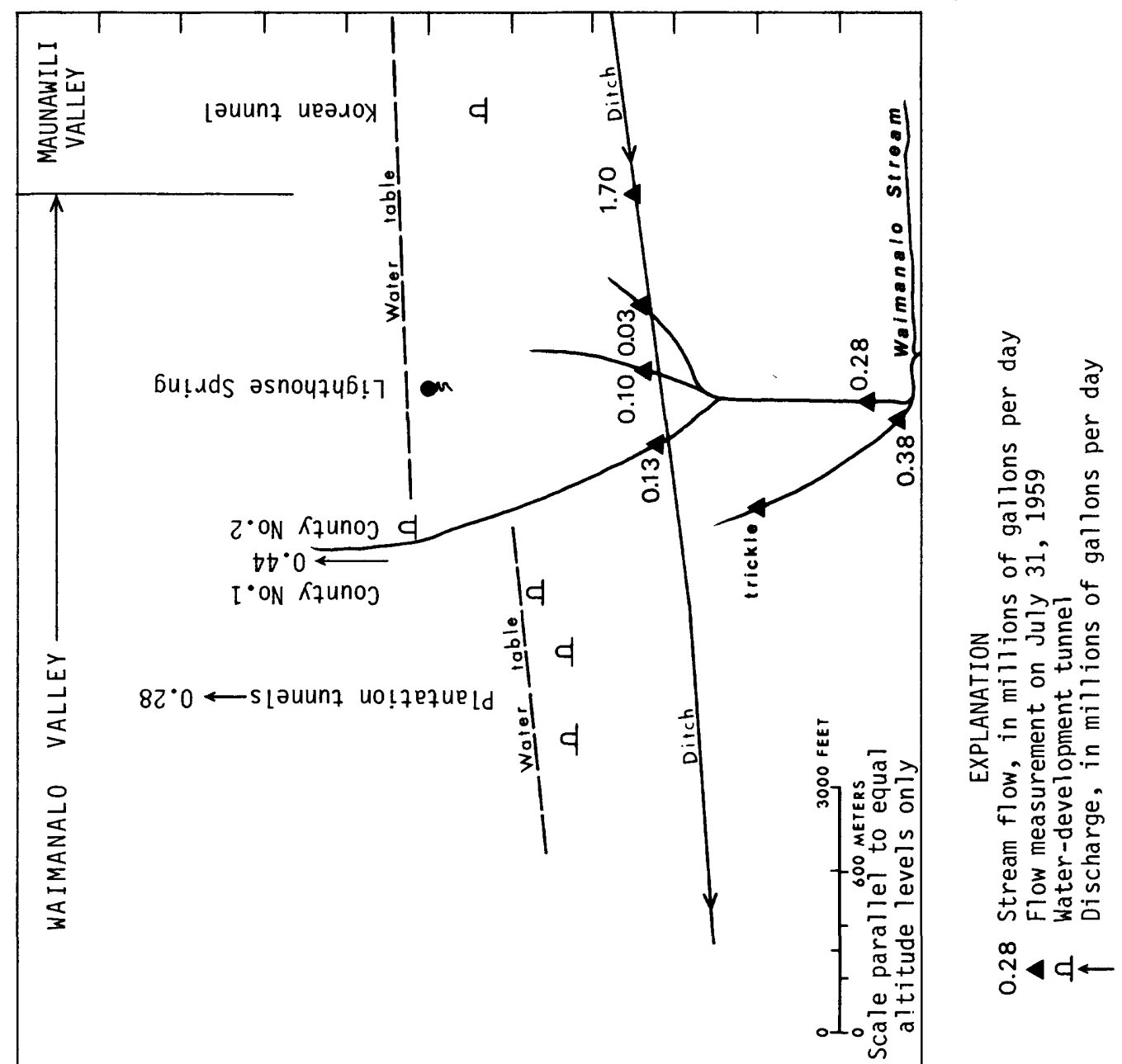

인

$+4$

ำ

穴

- $\frac{0}{\pi}$

य)

T.

$\frac{1}{3}$

范

更

inc

$\overline{0} \cdot=$

ᄃ

ว

in 崩

n $n \frac{x}{c}$

$0_{3} \cdot \Sigma$

3

$\therefore \stackrel{n}{c}$

a $\frac{0}{0}$

능

d)

-

㐫 文

苾

43

4 은

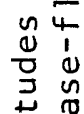

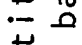

б) $\frac{0}{\pi}$

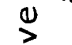

$\frac{1}{2}$

$\frac{0}{0}$

ब)

OI $0 \longleftarrow 20-\varepsilon$ เOZ LIวM '

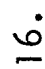

立 
Water confined in deep sedimentary material.--Well 2043-01 which was drilled to a depth of 999 feet in about 1891 from an altitude of 26 feet, tapped flowing artesian water in valley-filling sediments. The well was redrilled in 1937 to a depth of 730 feet at which time the logs indicated the presence of water-worn pebbles at the bottom. The well has been pumped at a rate of $140 \mathrm{gal} / \mathrm{min}$ with a drawdown of 15 feet. It was sealed in April 1970 . The water probably represents, in part, leakage or drainage of dike-impounded water in the dike complex.

Basal water in coastal-plain sediments.--Basal water occurs in the sediments underlying the coastal plain. In addition to rainfall on the coastal plain, the sediments are recharged by return irrigation water and all the overland flow of water from higher areas not entering the stream channels because there are no storm drains in the area.

Ground water occurs near and at shallow depths below sea level in the coastal-plain sediments. The chloride concentration of the water in the sediments ranges from near fresh to saline. Samples of ground-water inflow into streams in 1961 (Takasaki, Hirashima, and Lubke, 1969) indicated that the inflow was nearly fresh. Chloride concentration records obtained prior to 1960 and samples of the water taken during 1960 and 1961 in wells drilled for fire protection in Bellows Air Force Base indicated a wide range in the chloride concentration. Observation of water-level fluctuations in these wells during this period suggested that part of the ground water was confined. The fire-protection wells, which served as individual fire hydrants, were drilled by the U.S. Air Force in 1943.

Recharge tests were made by the U.S. Geological Survey at well 2042-03 in 1965 in response to a request by the State Division of Water and Land Development. The purpose was to investigate the permeability of the coastal sediments and the feasibility of disposing treated sewage effluent into them by injection wells. Change or rise in water level was observed at the well recharged (2042-03) and at an observation well 2042-02 about 900 feet away. Well 2042-03 was capable of being recharged for at least 8 hours at a rate of $650 \mathrm{gal} / \mathrm{min}$ with a water-level $r$ ise of $10 \mathrm{feet}$. The well was also pumped at a rate of $150 \mathrm{gal} / \mathrm{min}$ for $1-1 / 2$ hours with a drawdown of 0.7 foot at an intermission during the recharge test. 
The recharge test was sufficiently encouraging so that the State, in 1966, drilled eight core holes at and downgradient (seaward) of a then proposed sewage-treatment plant site. The results of the core drilling were published in a report by Lum and Stearns (1970). This exploratory drilling was followed by the drilling of three effluent disposal wells in 1967 and 1968. The results of this drilling and subsequent pumping and recharge tests on them were published in a report by Lum (1969). These wells are now in use as disposal wells for sewage treated at the plant.

The information gained from the drilling, water-level fluctuations and the recharge and discharge tests indicated that ground water in the reef limestones was partly confined and that the confining member was a thin but widespread clay layer lying about 30 feet below sea level (fig. 17). The ground water in the deeper reef limestones lying below the consolidated dune sands was also confined. All water in the deeper reef limestone was highly brackish to saline. Water in the dune limestone and the shallow reef limestone ranges from near fresh to brackish and is highly sensitive to marked increase in salinity with pumping. The reef limestone is highly permeable and the consolidated dunes only moderately so.

Aquifer performance tests were conducted on August 27, 1980, and in February 1981 to investigate the feasibility of developing water from the unconsolidated sands lying above the thin confining layer in the coastal plain. The aquifer tested is thin, ranging in thickness from about 20 to 30 feet (fig. 17). 


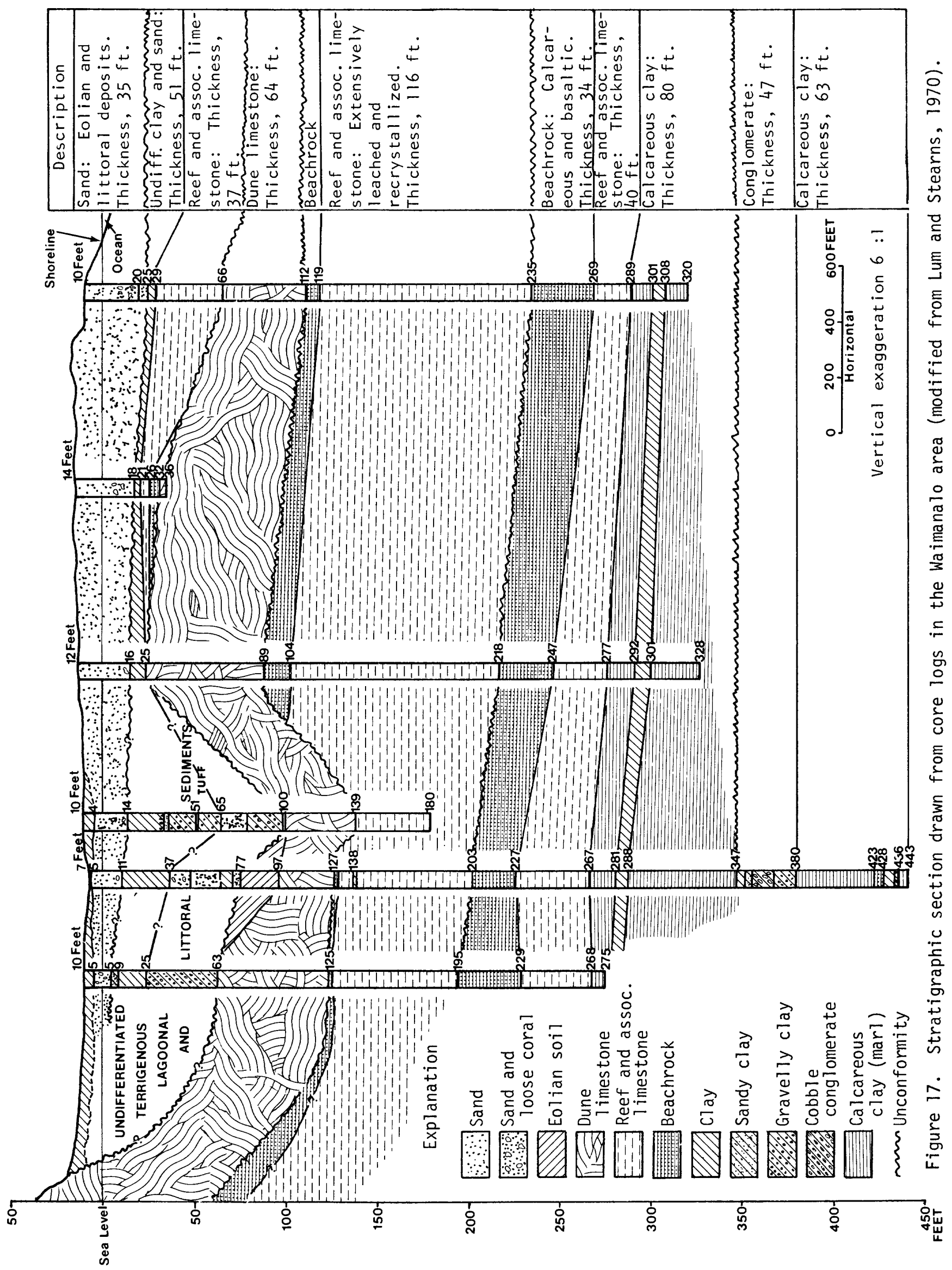


The test on August 27 consisted of pumping a drainage ditch in Bellows Air Force Base for about 8-1/2 hours. The ditch, which is open to the sea, is dug below water table and the water level in it fluctuates with the tide. During falling tides, ground water in the sediments discharges into the ditch and during rising tides, water in the ditch recharges the ground water in the sediments. The test was started near the beginning of a falling tide cycle and was ended during the succeeding rising tide cycle. A temporary dam was constructed to prevent water from the sea side from entering the ditch where the test pump was located. During the falling tide cycle, water in the ditch was allowed to pass through an opening in the dam. The opening was closed during the rising tide. The water in the ditch was pumped over the dam during both the falling and rising tides. There was no surface inflow into the ditch during the test. The results of the pumping test are shown in figure 18 . The ground-water inflow into the ditch during the test was estimated to be about 100,000 gallons. This was the volume of water needed to maintain the measured decline of water level in the ditch during the test.

A significant decline in the chloride concentration of the pumped water upstream of the dam prompted a second test. The second test on February 12 , 1981 was at a temporary hole excavated by a backhoe machine about 1,500 feet south of the first pump-test site. The well was pumped at an average rate of about $18 \mathrm{gal} / \mathrm{min}$ for about 5 hours. Owing to constant caving of the fine sand, a larger pumping rate was not possible. Results of this test are shown in figure 19. The water pumped was of excellent quality, ranging from a low chloride concentration of $100 \mathrm{mg} / \mathrm{L}$ to a high of $130 \mathrm{mg} / \mathrm{L}$. Owing to the crude nature of the pumping tests, no reliable figure for hydraulic conductivity (K) was possible. The first test indicated that $K$ was at least $200 \mathrm{ft} / \mathrm{d}$ and the second test indicated it was about $100 \mathrm{ft} / \mathrm{d}$ or less. Using these figures as a range, a crude estimate of the ground-water flux per unit length of shoreline is possible. 

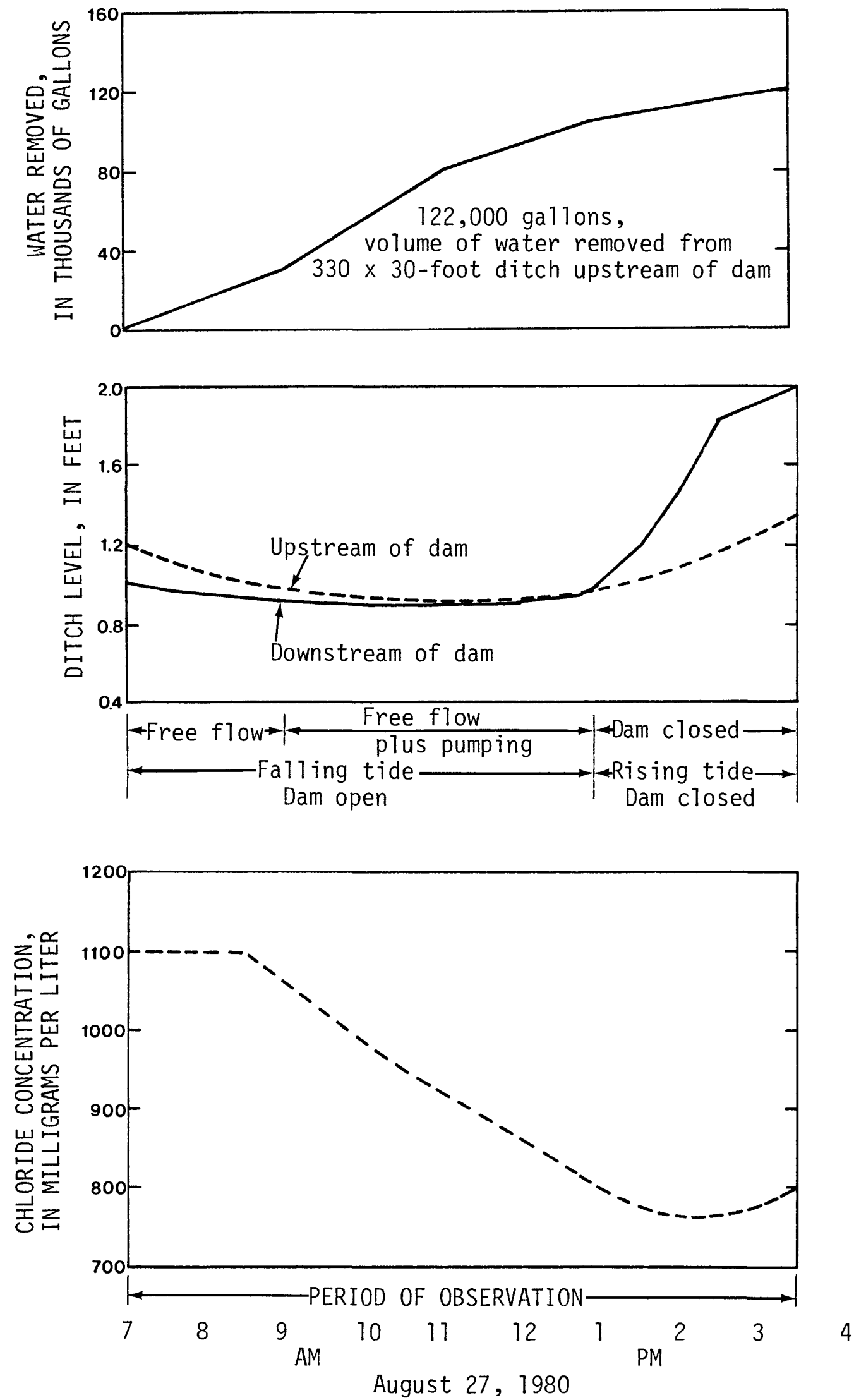

Figure 18. Results of pumping test of drainage ditch in the Waimanalo area. 


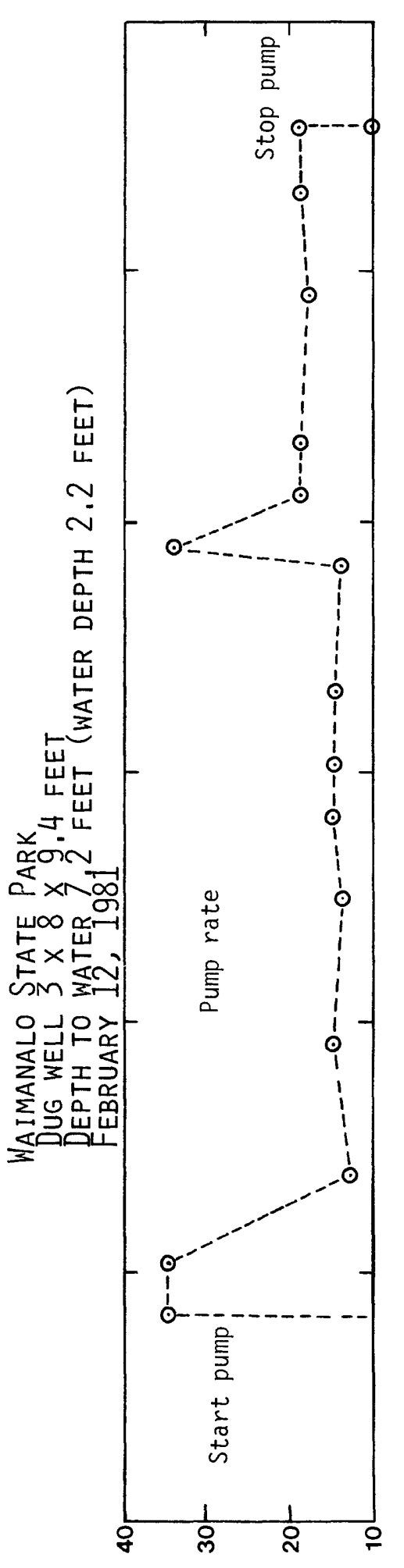

JINNIW $y \exists d$

SN077甘9 NI ' $\exists \perp \forall Y$ dWחd

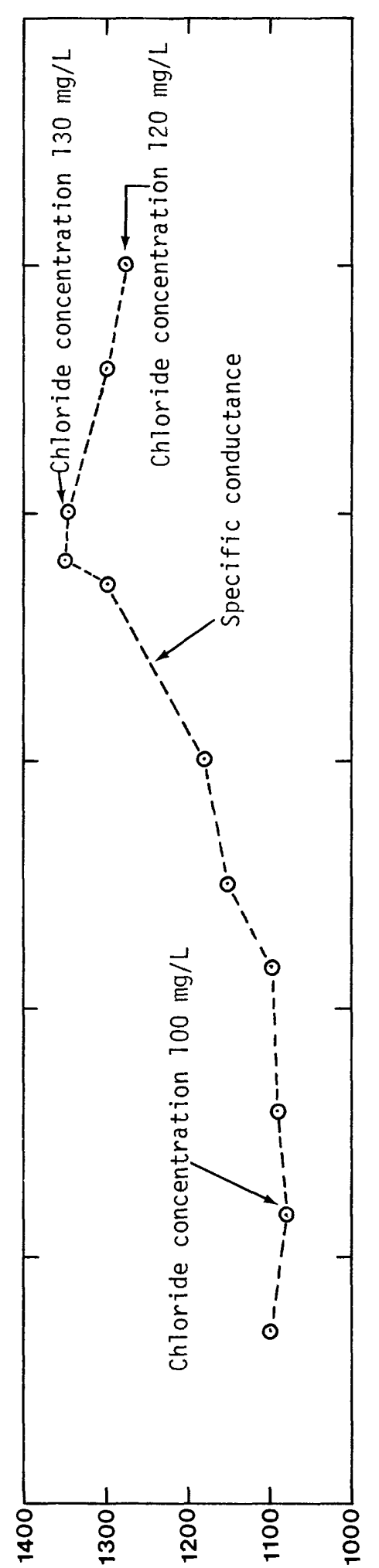

YJIJWILN3J Y Y S SOHWOYJIW NI ' $\exists$ JNHLONONOJ JIJIJJdS

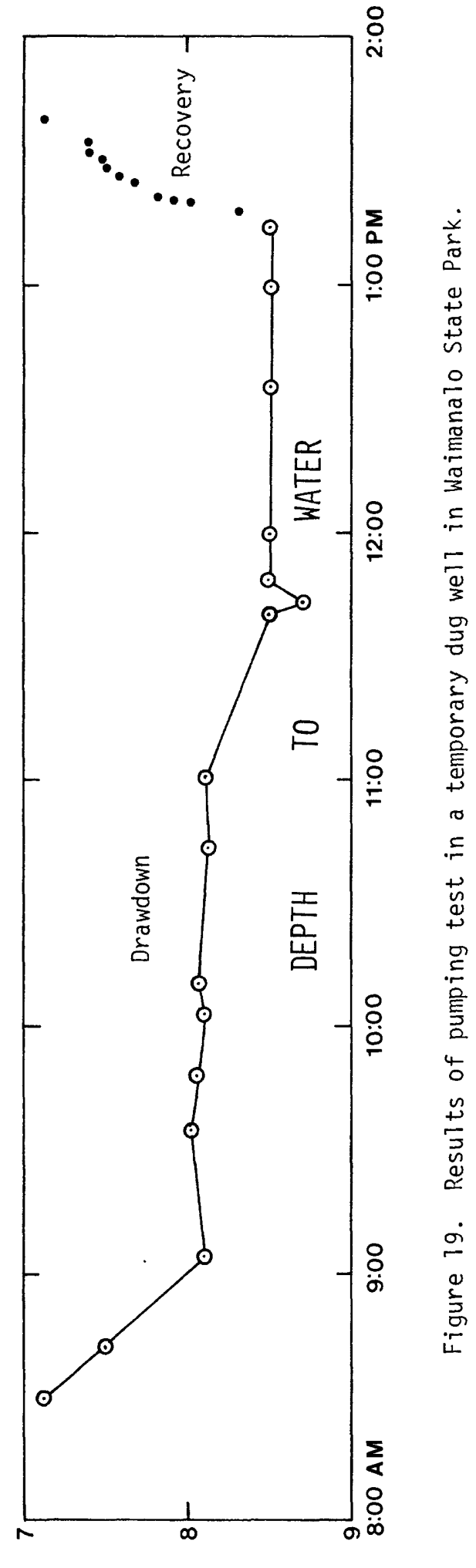

$7 \exists \Lambda \exists 7 \forall \exists S N \forall \exists W \quad \exists \wedge 08 \forall$ $1 \exists \exists I \mathrm{NI}$ ' $\exists Q \cap \perp I \perp 7 \mathrm{H}$ 
Using the relation:

$$
Q=K A \frac{d y}{d x}
$$

and specifying

$$
\begin{aligned}
& Q=\mathrm{flux} \text { per unit length of shoreline }=\mathrm{ft}^{3} / \mathrm{d} \text { per } 1000 \mathrm{ft} \\
& K=\text { hydraulic conductivity }-100 \mathrm{ft} / \text { day } \\
& A=\text { unit length shoreline } x \text { aquifer thickness }=1,000 \mathrm{ft} \times 25 \mathrm{ft} \\
& \frac{d y}{d x}=\text { ground-water gradient }=\text { estimated at } 8 \mathrm{ft} / \mathrm{mi} ;
\end{aligned}
$$

solving for $Q$

$$
\begin{aligned}
Q & =(100)(1,000 \times 25)(8 / 5,280) \\
& =3,800 \mathrm{ft}^{3} / \mathrm{d} \text { per } 1000 \mathrm{ft} \\
& =28,300 \mathrm{gal} / \mathrm{d} 1000 \mathrm{ft} ; \\
K & =200 \mathrm{ft} / \text { day } \\
Q & =7,600 \mathrm{ft}^{3} / \mathrm{d} \text { per } 1000 \mathrm{ft} \\
& =56,600 \mathrm{gal} / \mathrm{d} \text { per } 1000 \mathrm{ft} .
\end{aligned}
$$

The ground-water flux per 1,000 feet of shoreline is thus estimated to range from a low of about $28,000 \mathrm{gal} / \mathrm{d}$ to a high of at least 56,000 gal/d in the sediments. A more controlled pumping test is warranted to define better the properties of this valuable aquifer. The aquifer extends inland from shore for about 2,000 feet. If its porosity is but 5 percent, the storage per 1,000 feet of aquifer is $2.5 \mathrm{million}$ cubic feet or about $19 \mathrm{million}$ gallons. 
Past and potential development.--The earliest water supply other than that of the native Hawailans was developed by the Waimanalo Plantation Co., which was in existence from 1878 to 1947. The plantation started construction of Maunawili Ditch in 1878 to transport water from Maunawili Valley to the Waimanalo area for the irrigation of sugarcane. The first water-development tunnel was reportedly dug in 1888 in the upper mountainous part of the Waimanalo area and the first well (2043-01) was drilled in 1891 near the mill site in the lower coastal area. By 1900, the flow delivered by the ditch averaged between 1.0 to $1.5 \mathrm{Mgal} / \mathrm{d}$. During periods of $1 \mathrm{ittle}$ rain when ditch flow was low, water was pumped from a lagoon near the coast to augment the irrigation supply. Later, water pumped from Kawainui Swamp in Maunawili Valley was added to the plantation supply. Well 2143-01 was drilled in 1892 near the lagoon but was unused and subsequently sealed. Two more waterdevelopment tunnels were dug in the $1920^{\prime}$ 's to augment the irrigation supply. Another well (2044-01) was drilled in 1933 just above the level of Maunawili Ditch at an altitude of about 350 feet. This well was never used owing to its very low yield.

Five exploratory test holes were cored in 1935 below the level of Maunawili Ditch at altitudes ranging from 153 to 266 feet (fig. 15). All the holes were drilled to below sea level and all tapped water that was under artesian pressure. Even though three of these wells flowed, ground water in the area explored by the holes was not developed owing to the very low permeability of the rocks caused by secondary mineralization.

The last well for the plantation (2044-02) was drilled in 1937 near the site of one of the exploratory holes drilled in 1935 at an altitude of about 150 feet. The well was drilled to a depth of 270 feet in mostly weathered rock and was abandoned when the casing collapsed.

The first public water system was installed in 1926 by the then Territorial Government. The system was supplied by an existing tunnel until 1940 when another tunnel was added. After the liquidation of Waimanalo Plantation in 1947, the plantation's well, 2043-01, and tunnels were added to the publicsupply system, followed in 1956 by the addition of well 2043-02. 
During World War 11, water was piped from the Maunawili area to meet the growing demands for water at Bellows Air Force Base. At least eight wells were drilled in calcareous sediments on the Base to serve as supply wells for fire protection.

A stock supply well (2042-04) was drilled in calcareous sediments in 1953. Another well (2042-13) was drilled in the same area in 1969 to supply water for limestone quarrying operations that existed there.

The latest drilling included eight test borings in 1966 to investigate the permeability of the sediments for the purpose of disposing sewage effluent into them by wells, followed by the drilling of three effluent wells in 1967 and 1968 .

Information on the Waimanalo tunnels and wells is given in table 4.

Except for minimal pumping from well 2043-02 that taps the volcanic aquifer and water for quarrying operations supplied by well 2042-13 that taps the sedimentary aquifer, the current development scheme utilizes only the low-flow discharge of tunnels above an altitude of $400 \mathrm{feet}$. As in Maunawili Valley, tunnels tapped dike-impounded reservoirs in the marginal dike zone where the rocks are more permeable than in the dike complex that abuts the marginal dike zone on the downgradient (north) side. Further development, solely aimed at the steady-state discharge by horizontal tunneling, would not permanently increase discharge. Wells, instead, that can deplete storage by pumping at rates higher than the steady-state discharge can increase the supply during the period when demand is high. Storage can be replenished in the low-demand periods when pumpage is small or nil. The most favorable area for wells would be deep inside the existing tunnels where the chances of tapping fresh rocks at shallow depths are much greater than outside the tunnels where the rocks are deeply weathered.

Small local demands in the upland areas can be supplied by wells drilled into rocks of low permeability of the dike complex. The yields will generally be low with high pumping drawdowns but these disadvantages are somewhat off set by shallow water levels and proximity of the water supply to the use area.

Near the coast, the shallow supply in the coastal plain sediments previously described can easily be developed for use. 
Table 4. Tunnels and wells in Waimanalo

\begin{tabular}{|c|c|c|c|c|c|c|c|c|c|c|c|c|c|c|}
\hline$\frac{\text { Well }}{\text { New }}$ & $\frac{\text { No. }}{01 \mathrm{~d}}$ & $\begin{array}{l}\text { Di am- } \\
\text { eter } \\
\text { ( in.) }\end{array}$ & $\begin{array}{l}\text { Alti- } \\
\text { tude } \\
(f t)\end{array}$ & $\begin{array}{l}\text { Depth } \\
(f t)\end{array}$ & $\begin{array}{l}\text { Ca- } \\
\text { sing } \\
(\mathrm{ft})\end{array}$ & $\begin{array}{l}\text { Aqui- } \\
\text { fer }\end{array}$ & $\begin{array}{l}\text { Year } \\
\text { drilled }\end{array}$ & $\frac{\text { Head, }}{\text { High }}$ & $\frac{\mathrm{d}, \mathrm{ft}}{\text { Low }}$ & $\begin{array}{r}\mathrm{Chlo} \\
\text { concen } \\
\mathrm{mg} \\
\mathrm{High}\end{array}$ & $\begin{array}{l}\text { de } \\
\text { Low ion, }\end{array}$ & Use & $\begin{array}{l}\text { ecific } \\
\text { pacity } \\
\text { al/min) } \\
\mathrm{ft}]\end{array}$ & Remarks \\
\hline $2042-01$ & $408-6$ & -- & 20 & 100 & -- & $\begin{array}{l}\text { Sand- } \\
\text { stone }\end{array}$ & 1943 & -- & -- & 116 & -- & $\begin{array}{l}\text { Aban- } \\
\text { doned }\end{array}$ & $-\cdots$ & Log available. \\
\hline $\begin{array}{l}2042-02 \\
2042-03\end{array}$ & $\begin{array}{l}408-7 \\
408-8\end{array}$ & $\begin{array}{l}12 \\
12\end{array}$ & $\begin{array}{r}9 \\
12\end{array}$ & $\begin{array}{l}58 \\
88\end{array}$ & $\begin{array}{l}58 \\
88\end{array}$ & $\begin{array}{l}\text { do. } \\
\text { do. }\end{array}$ & $\begin{array}{l}\text { do. } \\
\text { do. }\end{array}$ & $\begin{array}{l}3.4 \\
5\end{array}$ & $\begin{array}{l}0.5 \\
2\end{array}$ & $\begin{array}{l}20,000 \\
11,000\end{array}$ & $\begin{array}{r}2350 \\
300\end{array}$ & $\begin{array}{l}\text { do. } \\
\text { do. }\end{array}$ & $\begin{array}{l}140 \\
200\end{array}$ & $\begin{array}{l}\text { Tidal efficiency } 80 \text { percent. } \\
\text { Tidal efficiency } 70 \text { percent; } \\
\text { recharge test. }\end{array}$ \\
\hline $2042-04$ & $420-1$ & 2 & 70 & 100 & 100 & do. & 1953 & --- & -.- & 185 & -- & do. & --- & - \\
\hline $2042-05$ & T136 & -- & -- & -- & -- & -- & 1966 & -- & $\cdots$ & --- & -- & --- & $-\cdots$ & 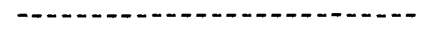 \\
\hline 2042-06 & T137 & -- & -- & -- & -- & -- & do. & -- & -- & --- & -- & --- & --- & - \\
\hline 2042-07 & T138 & -- & -- & -- & 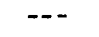 & -- & do. & -- & $\cdots$ & --- & -- & $\cdots$ & $--\cdot$ & - \\
\hline $2042-08$ & T139 & -- & -- & -- & -- & -- & do. & -- & $\cdots$ & $\cdots$ & -- & $\cdots$ & $\cdots$ & 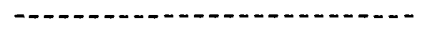 \\
\hline $2042-09$ & $T 140$ & -- & -- & -- & -- & -- & do. & --- & -- & $-\cdots$ & -- &.-- & $\ldots$ & - \\
\hline $2042-10$ & $\mathrm{~T} 141$ & -- & -- & -- & --- & -- & do. & -- & -- & --- & -- & --- & --- & 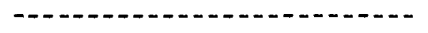 \\
\hline 2042-11 & T142 & -- & -- & -- & --- & -- & do. & --- & --- &.-- & -- & $-\cdots$ &.-- & n \\
\hline $2042-12$ & T142-1 & $1--$ & -- & -- & -- & -- & do. & --- & -- & --- & -- & $\cdots$ & $-\cdots$ & 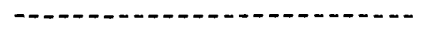 \\
\hline $2042-13$ & $420-1 A$ & $A--$ & -- & 160 & $1 / 50$ & Coral & 1969 & -- & -- & 2100 & 1550 & $\begin{array}{l}\text { Indus- } \\
\text { trial }\end{array}$ & 700 & Perforations $50 \mathrm{ft}$. \\
\hline $2042-14$ & $408-9 A$ & $A--$ & -- & -- & -- & -- & 1968 & -- & -- & $-\cdots$ & -- & --- & $\cdots$ & - \\
\hline 15 & $408-98$ & B -- & -- & -- & -- & -- & do. & -- & -- & --- & -- & $\cdots$ & $-\cdots$ & 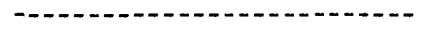 \\
\hline $2042-16$ & $408-9 C$ & $\begin{array}{c}c-- \\
-\end{array}$ & $=-$ & -- & --- & --- & do. & --- & --- & --- & -- & $\ldots$ & $\cdots$ & 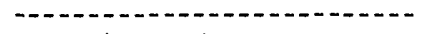 \\
\hline $2043-01$ & 408 & 6 & 26 & 999 & 253 & $\begin{array}{l}\text { Sedi- } \\
\text { ment }\end{array}$ & 1891 & 32 & 28 & 53 & 24 & Sealed & 9 & $\begin{array}{l}\text { Pump } 140 \mathrm{gal} / \mathrm{min} \text {; drawdown } \\
15 \mathrm{ft} \text {. }\end{array}$ \\
\hline $2043-02$ & 420 & 12 & 142 & 280 & 136 & Lava & 1956 & 31 & 29 & 30 & -- & $\begin{array}{l}\text { Muni- } \\
\text { cipal }\end{array}$ & 2 & - \\
\hline $2044-01$ & 409 & 8 & 310 & 403 & 47 & do. & 1933 & 308 & 273 & 46 & -- & None & 0.3 & $\begin{aligned} \text { Log: } & 0-98 \mathrm{ft} \text { sediment, 98- } \\
& 440 \mathrm{ft} \text { weathered lava; } \\
& \text { pump } 43 \mathrm{gal} / \mathrm{min} \text {, draw- } \\
& \text { down } 168 \mathrm{ft} .\end{aligned}$ \\
\hline $2044-02$ & 423 & 6 & 150 & 270 & 238 & do. & 1937 & -- & -- & --- & -- & $\begin{array}{l}\text { Aban- } \\
\text { doned }\end{array}$ & --- & Well collapsed. \\
\hline $2044-03$ & $\cdots-$ & -- & -- & -- & -- & $-\cdots$ & --- & -- & -- & --- & -- & --- & --- & Honolulu BWS tunnel 1 . \\
\hline-04 & $\cdots$ & - & -- & -- & $\ldots$ & $\ldots$ & $-\cdots$ & -- & --- &.-- & -- & $\ldots$ & $-\cdots$ & Honolulu BWS tunnel II. \\
\hline $2045-03$ & $-\cdots$ & -- & -- & -- & -- & -- & $\cdots$ & -- & -- & $\cdots-$ & -- & $\cdots$ & --- & Honolulu BWS tunnel 111. \\
\hline $2045-04$ &.-- & -- & -- & -- & -- & -- & $-\cdots$ & --- & -- & --- & -- & $\ldots-$ & $-\cdots$ & County tunnel 1. \\
\hline $2045-05$ & $-\cdots$ & -- & -- & -- & $\cdots$ & $\ldots$ & --- & --- & --- & --- & -- & $\ldots-$ & $-\cdots$ & Honolulu BWS tunnel IV. \\
\hline $2142-01$ & $408-3$ & -- & 15 & 68 & -- & 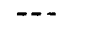 & 1943 & 4.2 &.-- & 95 & 20 & do. & & \\
\hline $2142-02$ & $408-4$ & -- & 20 & 75 & -- & -- & do. & -- & -- & 71 & & do. & 900 & $\begin{aligned} \text { Log: } & 0-7 \mathrm{ft} \text { fill, } 7-27 \mathrm{ft} \\
& \text { mar ine sediment, } \\
& 27-75 \text { clay. }\end{aligned}$ \\
\hline $2142-03$ & $408-5$ & -- & 20 & $1 / 41$ & -- & $-\cdots$ & do. & -- & -- & 238 & 101 & do. & 55 & $\begin{aligned} \text { Log: } & 0-40 \mathrm{ft} \text { marine sedi- } \\
& \text { ment, } 40-148 \mathrm{ft} \text { sedi- } \\
& \text { ment; measured depth. }\end{aligned}$ \\
\hline 214 & 421 & -- & $-\overline{2}-$ & -- & -- & -- & 1892 & --- & --- & $-\cdots$ & -- &.-- & $\ldots$ & 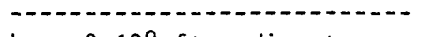 \\
\hline $2143-02$ & $421-1$ & -- & 50 & -- & $\cdots$ & --- & 1952 & --- & $\cdots$ & $-\cdots$ & -- & do. & $\cdots$ & $\begin{aligned} \text { Log: } & 0-128 \text { ft sediment, } \\
& 128-140 \mathrm{ft} \text { rock; no } \\
& \text { water. }\end{aligned}$ \\
\hline $2242-01$ & $408-1$ & - & 10 & 90 & -- & -- & 1943 & -- & -- & 4400 & -- & $-\cdots$ & $\cdots$ & $\begin{aligned} & \text { Log: } 0-90 \text { ft marine sedi- } \\
& \text { ment. }\end{aligned}$ \\
\hline $2243-01$ & $408-2$ & - & -- & -- & -- & -- & do. & -- & -- & 71 & -- & $\cdots$ & 2000 & $\begin{aligned} \text { Log: Marine sediment with } \\
\\
\text { clay at } 32 \text { to } 40 \mathrm{ft} \\
\text { and } 67-75 \mathrm{ft} .\end{aligned}$ \\
\hline
\end{tabular}

1/ See reinarks. 
The Makapuu area, less than 1 square mile, includes the windward (north) side of the island's east end and features two scenic offshore islands and a broad protrusion of a generally narrow coast. These features along the koko $r$ ift are products of recent lava flows and pyroclastics of the Honolulu Group (fig. 20). Makapuu Beach lies on lava flows (Kaupo) that erupted near shore and flowed into shallow water about the same time as the lavas on Kaohikaipu Island (Bird Refuge). Earlier tuff eruptions built up Manana Island, which is popularly know as Rabbit Island. The area is bounded on the south by moderately high cliffs that are made up of southerly dipping lava flows of the Koolau Volcanics that are sparsely intruded by both northwesterly and northeasterly trending dikes. Alluvium and talus lie at the foot of the volcanic cliffs.

Owing to very low rainfall except during infrequent storms, fresh ground-water reservoirs are, at best, very small and probably limited to the area underlain by alluvium and talus at the base of cliffs. There is no freshwater in the offshore islands.

Sea Life Park, a marine-life park, is located on lava flows of the Honolulu Group near Makapuu Beach. The Park utilizes these highly permeable lavas for saltwater supply and disposal. Saltwater is pumped heavily from wells tapping these lavas for their marine life aquarium and pool supplies and the effluent is discharged into other wells tapping these same lavas. The initial test hole was drilled in 1960 which was followed by the drilling of five supply wells and three disposal wells in 1963. This was followed by the drilling of a supply well in 1966 and a disposal well in 1968 and 1969. A saltwater well was recently drilled in 1981 for neighboring Oceanic Institute's mariculture program. Records of the wells drilled are given in table 5 and the location of the saltwater well is shown in figure 20 .

Sal twater pumped from wells is far superior in quality with respect to having less suspended sediments and organic matter than water pumped directly from the sea. Of chief concern is developing water having a salinity approaching that of seawater. 


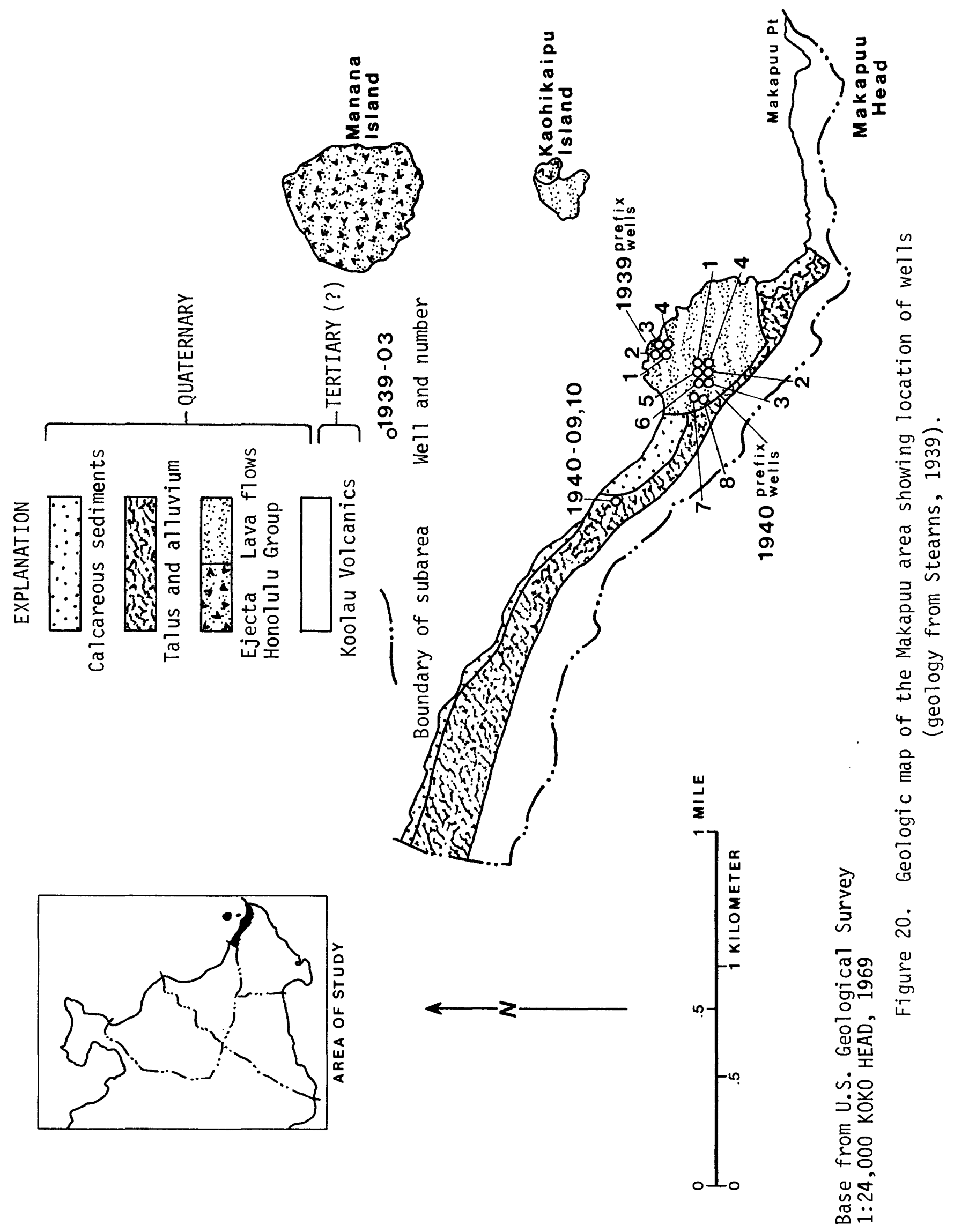


Table 5. Wells in Makapuu area

\begin{tabular}{|c|c|c|c|c|c|c|c|c|c|c|c|c|c|c|c|}
\hline \multirow{2}{*}{$\frac{\text { Well }}{\text { New }}$} & \multirow{2}{*}{$\frac{\text { No. }}{01 d}$} & \multirow{2}{*}{$\begin{array}{l}\text { Diam- } \\
\text { eter } \\
\text { ( in.) }\end{array}$} & \multirow{2}{*}{$\begin{array}{l}\text { Alti- } \\
\text { tude } \\
(f t)\end{array}$} & \multirow{2}{*}{$\begin{array}{l}\text { Depth } \\
(\mathrm{ft})\end{array}$} & \multirow{2}{*}{$\begin{array}{l}\text { Ca- } \\
\text { sing } \\
(f t)\end{array}$} & \multirow{2}{*}{$\begin{array}{l}\text { Aqui- } \\
\text { fer }\end{array}$} & \multirow{2}{*}{$\begin{array}{c}\text { Year } \\
\text { drilled }\end{array}$} & \multirow{2}{*}{$\frac{\text { Head, }}{\text { High }}$} & \multirow{2}{*}{$\frac{\mathrm{ft}}{\text { Low }}$} & \multicolumn{2}{|c|}{$\begin{array}{c}\text { Chloride } \\
\text { concentration, } \\
\mathrm{mg} / \mathrm{L}\end{array}$} & \multirow[b]{2}{*}{ Use } & \multirow{2}{*}{\multicolumn{2}{|c|}{$\begin{array}{c}\text { Specific } \\
\text { capacity } \\
{[(\mathrm{gal} / \mathrm{min}) / f t]}\end{array}$}} & \multirow[b]{2}{*}{ Remarks } \\
\hline & & & & & & & & & & $\mathrm{High}$ & Low & & & & \\
\hline $1939-01$ & $420-7$ & 18 & 2 & 26 & 25 & Lava & 1963 & $\cdots$ & $\cdots$ & $\cdots$ & $\cdots$ & $\begin{array}{l}\text { Sea } \\
\text { Life } \\
\text { Park }\end{array}$ & 1300 & $\cdots-1$ & 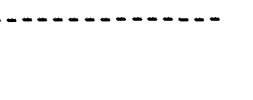 \\
\hline $1939-02$ & $420-8$ & 18 & 2 & 25 & 24 & do. & do. & $\cdots$ & -- & 17,600 & 16,600 & do. & 2500 & $\cdots-\cdots$ & 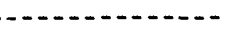 \\
\hline $1939-03$ & $420-9$ & & 2 & 15 & 0 & do. & do. & $\cdots$ & -- & $\cdots$ & $\cdots$ & do. & $\cdots$ & ---- & 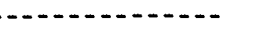 \\
\hline $1939-04$ & $429-10$ & & 2 & 15 & 0 & do. & do. & $\ldots$ & $-\cdot-$ & $\ldots$ & $\cdots$ & do. & $-\cdots$ & $\cdots-\cdots$ & 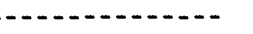 \\
\hline $1940-01$ & T88 & 5 & 25 & 80 & -- & do. & 1960 & -- & $-\cdot$ & $-\cdots$ & $\cdots-$ & $\cdots$ & $\cdots$ & $-\cdots-n$ & - \\
\hline $1940-02$ & $420-2$ & -- & 42 & 105 & -- & do. & 1963 & 0.4 & $\cdots$ & 16,400 & $\cdots-$ & do. & 100 & $\begin{aligned} & \log : 0 \\
& 5 \\
& 7\end{aligned}$ & $\begin{array}{l}0-59 \text { ft lava, } \\
59-73 \mathrm{ft} \text { coral, } \\
73-105 \mathrm{ft} \text { lava. }\end{array}$ \\
\hline $1940-03$ & $420-3$ & 14 & 28 & 70 & 30 & do. & do. & $\cdots$ & -- & $\cdots$ & $\cdots$ & $\begin{array}{l}\text { Dis- } \\
\text { posal }\end{array}$ & $\cdots$ & $\log : \frac{0}{3}$ & $\begin{array}{l}0-38 \text { ft lava, } \\
38-70 \mathrm{ft} \text { coral. }\end{array}$ \\
\hline $1940-04$ & $420-4$ & 16 & 32 & 98 & 36 & do. & do. & -- & -- & $\cdots$ & $-\cdots$ & do. & 1100 & -og: $\begin{aligned} 0 \\
6 \\
9\end{aligned}$ & $\begin{array}{l}0-62 \mathrm{ft} \text { lava, } \\
62-94 \mathrm{ft} \text { coral, } \\
94-98 \mathrm{ft} \text { lava. }\end{array}$ \\
\hline $1940-05$ & $420-5$ & 16 & 32 & 100 & 32 & do. & do. & $\cdots$ & -- & $-\cdots$ & $\cdots$ & do. & $-\cdots$ & $\log : 0$ & $\begin{array}{l}0-52 \mathrm{ft} \text { lava, } \\
52-100 \mathrm{ft} \text { coral. }\end{array}$ \\
\hline $1940-06$ & $420-6$ & 16 & 32 & 100 & 32 & do. & do. & $\cdots$ & $-\cdot$ & $\cdots$ & $\cdots$ & do. & $\cdots$ & Log: 0 & $\begin{array}{l}0-52 \mathrm{ft} \text { lava, } \\
52-100 \mathrm{ft} \text { coral. }\end{array}$ \\
\hline $1940-07$ & $420-11$ & 16 & 20 & 80 & 50 & do. & 1966 & $\cdots$ & -- & 13,700 & $\cdots$ & $\begin{array}{l}\text { Sea } \\
\text { Life } \\
\text { Park }\end{array}$ & $\cdots$ & $\begin{aligned} & \log : 0 \\
& 2 \\
& 4 \\
& p \\
& 3\end{aligned}$ & $\begin{array}{l}0-20 \mathrm{ft} \text { lava, } \\
20-45 \mathrm{ft} \text { coral, } \\
45-80 \mathrm{ft} \text { lava, } \\
\text { perforations } \\
38 \mathrm{ft} \text {. }\end{array}$ \\
\hline $1940-08$ & $420-12$ & 16 & -- & 175 & 30 & do. & 1968 & $\cdots$ & -- & $-\cdots$ & $\cdots$ & $\begin{array}{l}\text { Dis- } \\
\text { posal }\end{array}$ & 175 & $\log : \begin{array}{r}0 \\
1 \\
0 \\
f\end{array}$ & $\begin{array}{l}0-165 \text { ft lava, } \\
165-173 \mathrm{ft} \\
\text { coral, 173-175 } \\
\text { ft lava. }\end{array}$ \\
\hline $1940-09$ & $420-13$ & 8 & 30 & 39 & -- & -- & 1969 & $\cdots$ & $\cdots$ & 1,600 & $-\cdots$ & $\begin{array}{l}\text { Aban- } \\
\text { doned }\end{array}$ & $\cdots$ & $-m-$ & - \\
\hline $1940-10$ & $\cdots+\cdots$ & - 16 & 35 & 262 & 125 & do. & 1981 & $\cdots$ & $\cdots$ & 19,000 & $\cdots$ & $\begin{array}{l}\text { Mar icul- } \\
\text { ture }\end{array}$ & -175 & Log: $\frac{0}{4}$ & $\begin{array}{l}0-40 \text { ft soil, } \\
40-262 \text { lava. }\end{array}$ \\
\hline
\end{tabular}




\title{
Leeward (Southside) of Koolau Crest
}

\author{
Hawai i Kai (Maunalua) Area
}

Geologic setting

The Hawai Kai area, as outlined in this study, comprises the leeward (south) side of the island's eastern end and extends westward to but does not include Kuliouou Valley. Dominant landscape features in the southeastern part are volcanic vents, recent lava flows, and an abundance of tuff containing accidental inclusions of basalt and coral fragments. These features of the Honolulu Group lie outside the former shoreline of the Koolau Range and are separated from the Range by Kuapa Pond (fig. 21). The Honolulu volcanics rocks are underlain by coralline material, the depths to which generally depend on the distance offshore from the former shoreline. The Koolau Range in this area is sparsely intruded by dikes trending to the northwest and to the northeast (fig. 3). The rocks are shown in a geologic map (fig. 22).

\section{Water}

All streams are intermittent and quickly go dry after infrequent rains. Perennial water flow occurred only as springs at the toes of Kaluanui Ridge and the ridge that separates Kaalakei from Kuliouou Valley (Palmer, 1958). The chloride concentration of the spring water sampled in 1919, 1933 and 1934 ranged from about 500 to $1000 \mathrm{mg} / \mathrm{L}$. The springs, which represent basal-water discharge, have since been destroyed by backfilling or by excavation for a marina.

These springs and five shallow dug wells were the only sources of water in 1919 (Palmer, 1921). By 1933, two more shallow wells had been added. The location and the chloride concentration of water from the springs and wells are shown in figure 23 (Honolulu Board of Water Supply, 1935 and 1936). 


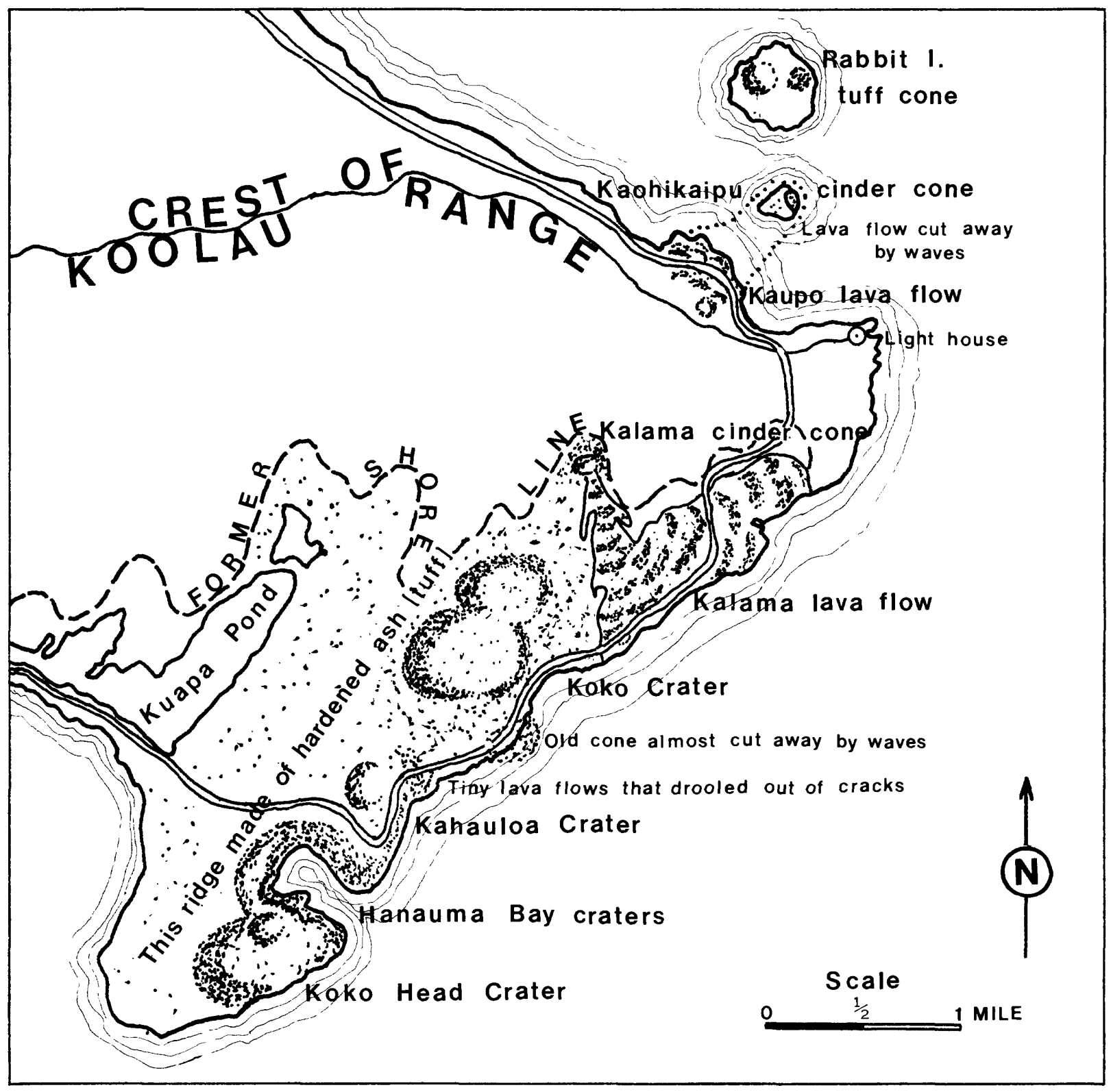

Figure 21. Hawaii Kai area showing landscape features of Honolulu Group and position of former shoreline (from Stearns, 1939). 


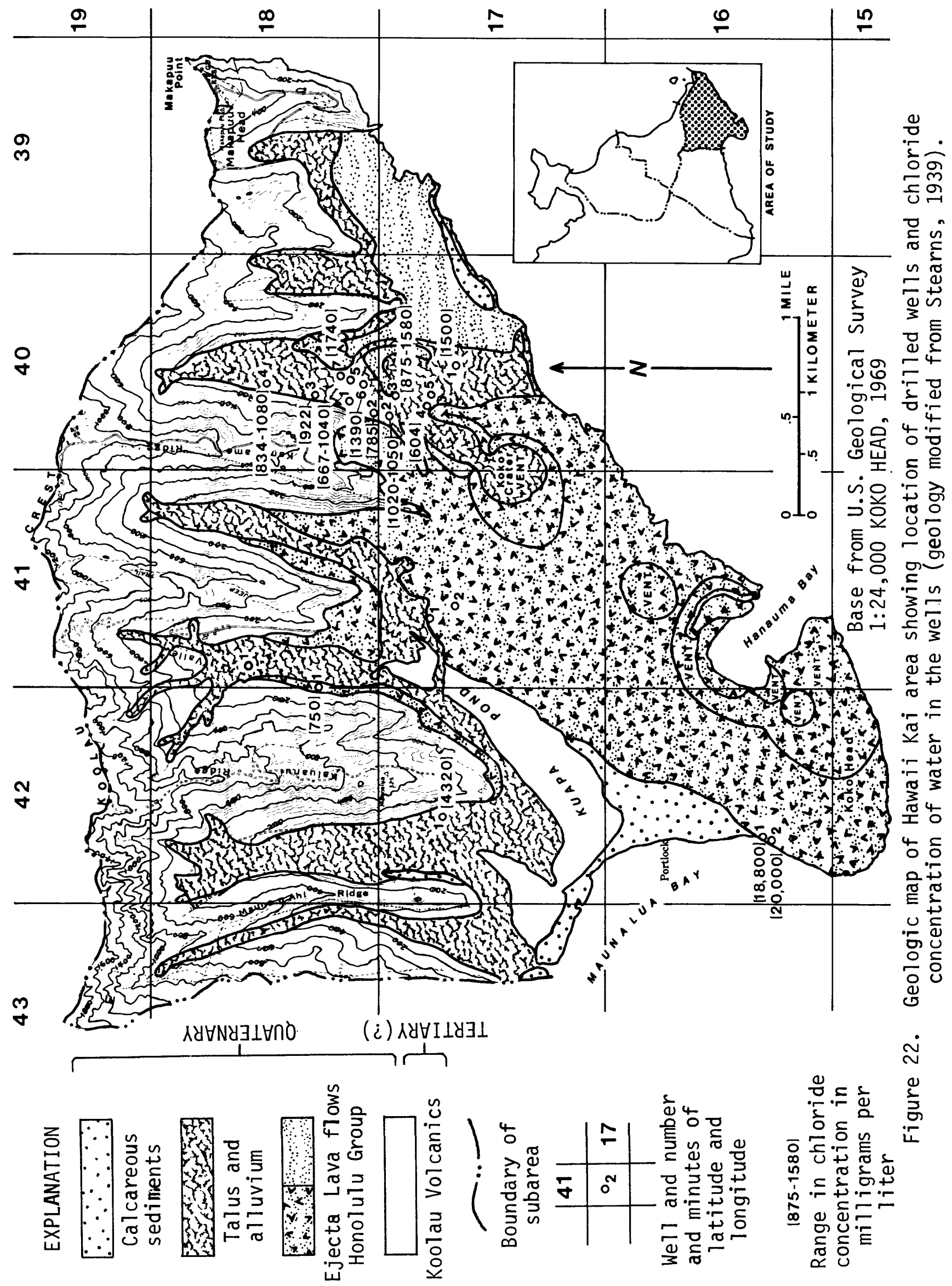




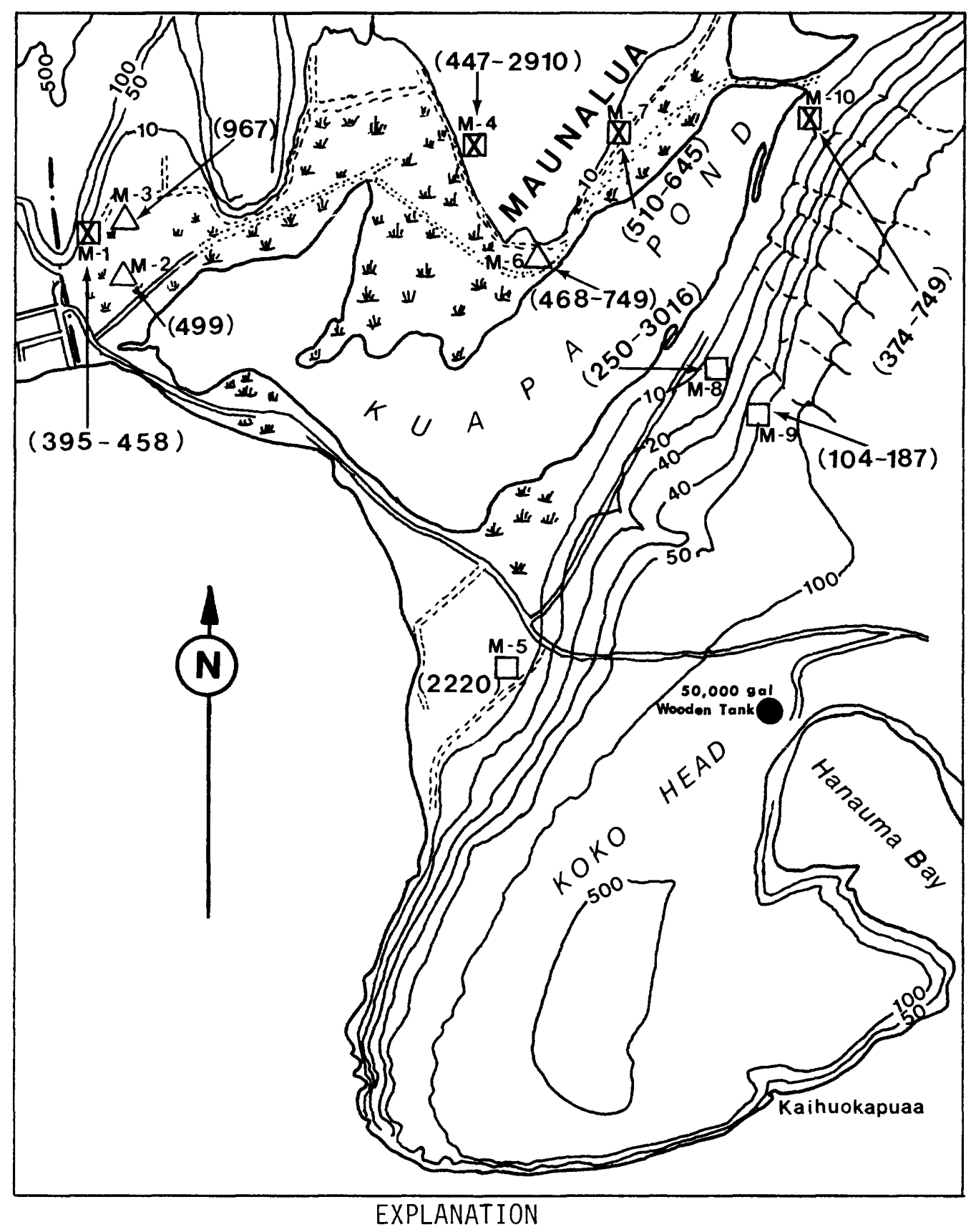

$\triangle \quad$ Basal spring

Dug we11

M-3 Sampling site

(510-645) Range in chloride concentration in milligrams per liter of samples taken in 1919, 1933-36

Figure 23. Hawaii Kai area showing location of dug wells, springs, and the range in chloride concentration of the water in them (modified from Honolulu Board of Water Supply, 1936). 
The first drilled well (1741-01) was constructed in 1937 at the base of the northwest slope of Koko Crater. It penetrated 52 feet of tuff and 180 feet of coral and other marine sediment before reaching the weathered surface of Koolau flows. The well was backfilled to a depth of 39 feet because of high salinity of the water at depth. A maximum head of 3.31 feet above mean sea level was reported during drilling when the well tapped ground water having a chlor ide concentration of $416 \mathrm{mg} / \mathrm{L}$. A second well (1741-02) was drilled in the same area in 1938. Subsequently 17 more wells were drilled mostly during the period 1945 to 1950. Most were drilled in Kalama Valley where pig farms, ousted from urban areas in Honolulu, were being relocated.

The drilled wells can be put into two groups, those drilled landward of the former shoreline and those drilled seaward of it. Wells landward of the former shoreline generally penetrate alluvium and tap water in the underlying Koolau rocks. Wells drilled seaward of the former shoreline generally tap water in tuff or recent lavas near the surface and in coralline material at depth. The wells landward of the former shoreline tap ground water that is recharged in the interior Koolau mountains while the wells seaward do not because they are hydrologically isolated from the Koolau aquifer. The wells seaward are recharged by local rainfall and by infrequent runoff from storms.

Heads ranging up to 3 feet above mean sea level in wells tapping Koolau rocks are generally higher and gradients are steeper than in wells tapping recent lava flows or coral limestone. The quality of the water from wells tapping the Koolau rocks is more stable in individual wells than the quality of water in wells tapping permeable sedimentary rocks where the quality is highly erratic. The quality of the water in shallow wells tapping poorly permeable tuff deposits is highly dependent on rainfall in the immediate area. Records of drilled wells are given in table 6.

None of the water tapped by drilled wells is potable and all the wells have been abandoned. The Hawaii Kai area once occupied by pig farms and small flower and truck farms is now one of the largest suburban developments on the is land. 
Table 6. Wells in Hawaii Kai area

\begin{tabular}{|c|c|c|c|c|c|c|c|c|c|c|c|c|c|c|}
\hline$\frac{\text { Well }}{\text { New }}$ & $\frac{\text { No. }}{01 d}$ & $\begin{array}{l}\text { Diam- } \\
\text { eter } \\
\text { (in.) }\end{array}$ & $\begin{array}{l}\text { Alti- } \\
\text { tude } \\
(f t)\end{array}$ & $\begin{array}{l}\text { Depth } \\
(f t)\end{array}$ & $\begin{array}{l}\text { Ca- } \\
\text { sing } \\
(f t)\end{array}$ & $\begin{array}{l}\text { Aqui- } \\
\text { fer }\end{array}$ & $\begin{array}{l}\text { Year } \\
\text { drilled }\end{array}$ & $\frac{\text { Head, }}{\text { High }}$ & $\frac{f t}{\text { Low }}$ & $\begin{array}{r}\text { Chlor } \\
\text { concent } \\
\text { mg/ } \\
\text { High }\end{array}$ & $\begin{array}{l}\text { ide } \\
\text { ration, } \\
\text { Low }\end{array}$ & Use $[(g$ & $\begin{array}{l}\text { pecific } \\
\text { apacity } \\
[/ / \mathrm{min}) / \mathrm{ft}]\end{array}$ & Remarks \\
\hline $1642-01$ & 445 & 6 & $\underline{\mathrm{e}} / 5$ & 220 & 169 & $\cdots$ & 1959 & -- & $\cdots$ & 18,800 & $-\cdots$ & $\begin{array}{l}\text { Aban- } \\
\text { doned }\end{array}$ & -- & $\begin{aligned} \text { Log: } & 0-165 \mathrm{ft} \text { tuff, } \\
& 165-220 \mathrm{ft} \text { coral. }\end{aligned}$ \\
\hline $1642-02$ & $445-1$ & 8 & $\cdots$ & 272 & 176 & $-\cdots$ & 1966 & -- & $\cdots$ & $-\cdots$ & 20,000 & Pond & -- & $\begin{aligned} \text { Log: } & 0-5 \mathrm{ft} \text { sediment, } \\
& 5-110 \mathrm{ft} \text { tuff, } \\
& 110-153 \mathrm{ft} \text { hard } \\
& \text { rock, } 153-272 \mathrm{ft} \\
& \text { coral. }\end{aligned}$ \\
\hline $1740-01$ & 427 & 6 & $\cdots$ & 125 & $\cdots$ & $\cdots$ & 1943 & $\cdots$ & $\cdots$ & 1500 & $\cdots$ & $\begin{array}{l}\text { Aban- } \\
\text { doned }\end{array}$ & $-\cdots$ & $\begin{aligned} \text { Log: } & 0-38 \mathrm{ft} \text { sediment, } \\
& 30-60 \mathrm{ft} \text { weathered } \\
& \text { rock, } 60-125 \mathrm{ft} \\
& \text { Honolulu lavas. }\end{aligned}$ \\
\hline $1740-02$ & 428 & 6 & 100 & 120 & 102 & $\cdots$ & 1945 & 0.6 & $\cdots$ & 1050 & 1020 & do. & 7 & $\begin{aligned} \text { Log: } & 0-35 \mathrm{ft} \text { sediment, } \\
& 35-120 \text { lava; pump } \\
& 75 \mathrm{gal} / \mathrm{min} \text {, draw- } \\
& \text { down } 11 \mathrm{ft} .\end{aligned}$ \\
\hline $1740-03$ & 433 & 6 & 96 & 105 & 105 & $\cdots$ & 1947 & 0.8 & -- & 1580 & 875 & do. & -- & $\begin{aligned} \text { Log: } & 0-50 \mathrm{ft} \text { sediment, } \\
& 50-105 \mathrm{ft} \text { volcan- } \\
& \mathrm{ic} \text { and layers of } \\
& \text { limestone. }\end{aligned}$ \\
\hline $1740-04$ & 439 & 8 & 139 & -- & --- & -..- & 1950 & 3.3 & $\ldots$ & 604 & -..- & do. & -- & Log not available. \\
\hline $1740-05$ & $439-1$ & 6 & 100 & 200 & 90 & $\ldots$ & 1951 & -- & $\cdots$ & $\cdots$ & --- & do. & $\cdots$ & $\begin{aligned} \text { Log: } & 0-52 \mathrm{ft} \text { gravel, } \\
& 52-156 \mathrm{ft} \text { Hono- } \\
& \text { lulu lavas, } \\
& 156-200 \mathrm{ft} \text { coral. }\end{aligned}$ \\
\hline $1741-01$ & 430 & 5 & 14 & 37 & 37 & $\cdots$ & 1937 & 1.7 & 1.5 & $-\cdots$ & $-\cdots$ & Sealed & $\cdots$ & $\begin{aligned} \text { Log: } & 0-52 \mathrm{ft} \text { cinders, } \\
& 52-233 \mathrm{ft} \text { coral } \\
& \text { and marine sedi- } \\
& \text { ments, } 233-260 \mathrm{ft} \\
& \text { weathered rock. }\end{aligned}$ \\
\hline $1741-02$ & 431 & 6 & 54 & 79 & 70 & $\cdots$ & 1938 & 1.5 & -.- & $-\cdots$ &..- & do. & $\ldots$ & Log: $0-79 \mathrm{ft}$ cinders. \\
\hline $1742-01$ & 441 & 8 & 23 & 48 & 26 & $\cdots$ & 1955 & 0.7 & -- & 4320 & $-\cdots$ & $\begin{array}{l}\text { Aban- } \\
\text { doned }\end{array}$ & 16 & $\begin{aligned} \text { Log: } & 0-13 \mathrm{ft} \text { sediment, } \\
& 13-19 \mathrm{ft} \text { cinders, } \\
& 19-32 \mathrm{ft} \text { coral, } \\
& 32-48 \mathrm{ft} \text { sediment, } \\
& \text { pump } 60 \mathrm{gal} / \mathrm{min}, \\
& \text { drawdown } 3.7 \mathrm{ft} .\end{aligned}$ \\
\hline $1840-01$ & 426 & 6 & 94 & 116 & 67 & Lava & 1945 & 1.3 & -- & 1040 & 667 & do. & -- & $\begin{aligned} \text { Log: } & 0-65 \mathrm{ft} \text { sediment, } \\
& 65-115 \mathrm{ft} \text { lava. }\end{aligned}$ \\
\hline $1840-02$ & 429 & 6 & 106 & 116 & 95 & do. & do. & 2.6 & -- & 785 & $\cdots$ & do. & -- & $\begin{aligned} \text { Log: } & 0-25 \mathrm{ft} \text { sediment, } \\
& 25-116 \mathrm{ft} \text { lava. }\end{aligned}$ \\
\hline $1840-03$ & 425 & 6 & 78 & 99 & 98 & do. & 1946 & 3.0 & $\cdots$ & 922 & $\cdots$ & do. & -- & $\begin{aligned} \text { Log: } & 0-40 \mathrm{ft} \text { sediment, } \\
& 40-99 \mathrm{ft} \text { lava. }\end{aligned}$ \\
\hline $1840-04$ & 424 & 7 & 88 & 110 & 108 & do. & 1947 & 2.2 & $\cdots$ & 1080 & 834 & do. & $\cdots$ & $\begin{aligned} \text { Log: } & 0-50 \mathrm{ft} \text { sediment, } \\
& 50-110 \mathrm{ft} \text { lava. }\end{aligned}$ \\
\hline $1840-05$ & 434 & 6 & 67 & 83 & 83 & do. & 1949 & 0.6 & $\cdots$ & 1300 & 1100 & do. & 30 & $\begin{aligned} \text { Log: } & 0-3 \mathrm{ft} \text { sediment, } \\
& 3-83 \mathrm{ft} \text { lava, } \\
& \text { pump } 60 \mathrm{gal} / \mathrm{min} \\
& \text { drawdown } 1.9 \mathrm{ft} .\end{aligned}$ \\
\hline $1840-06$ & 435 & 8 & 78 & 101 & 89 & do. & do. & 0.8 & 0.6 & 1390 & 1370 & do. & 25 & $\begin{aligned} \text { Log: } & 0-3 \mathrm{ft} \text { sediment, } \\
& 3-83 \mathrm{ft} \text { lava, } \\
& \text { pump } 33 \mathrm{gal} / \mathrm{min} \\
& \text { drawdown } 1.3 \mathrm{ft} .\end{aligned}$ \\
\hline $1840-07$ & 438 & 6 & 75 & 89 & 87 & do. & 1950 & 0.8 & $\cdots$ & 1740 & $-\cdots$ & do. & 800 & $\begin{aligned} \text { Log: } & 0-9 \mathrm{ft} \text { sediment, } \\
& 9-89 \mathrm{ft} \text { lava, } \\
& \text { pump } 82 \mathrm{gal} / \mathrm{min} \\
& \text { drawdown } 0.1 \mathrm{ft} .\end{aligned}$ \\
\hline $1841-01$ & 442 & 8 & 37 & 275 & 0 & do. & 1956 & --- & $\cdots$ & $-\cdots$ &.-- & do. & -- & $\begin{aligned} \text { Log: } & 0-68 \mathrm{ft} \text { sediment, } \\
& 68-275 \mathrm{ft} \text { weath- } \\
& \text { ered lava, very } \\
& \text { little water. }\end{aligned}$ \\
\hline $1842-01$ & 432 & 6 & 35 & 200 & 0 & do. & 1945 & 0.8 & $\cdots$ & 752 & $\cdots$ & do. & 100 & $\begin{aligned} \text { Log: } & 0-77 \mathrm{ft} \text { sediment, } \\
& 77-200 \mathrm{ft} \text { weath- } \\
& \text { ered lava. }\end{aligned}$ \\
\hline
\end{tabular}


Ground-water quality in Koolau rocks is best in the western part owing to the higher rainfall there. Water levels are higher and the quality of the water is better with distance landward from the former shoreline not from the present shoreline. The probability, however, of developing water of drinking-water quality in significant quantities appears to be small. A better scheme would be to develop water of a quality less than that commonly set for drinking water. Water in the chloride-concentration range of 500 to 1,000 $\mathrm{mg} / \mathrm{L}$ can be feasibly developed in significant quantities. Water of this quality can be used for blending to augment municipal drinking water supplies or used in ways other than domestic.

The locations of the drilled wells and the range in chloride concentration of water from them are shown in figure 22.

$$
\text { Kuliouou - Waialae Area }
$$

\section{Geohydrologic setting}

The Kuliouou-Waialae area, as outlined in this study, includes the lands of Kuliouou, Niu, Wailupe, Waialae Iki, and Waialae Nui (fig. 24).

Except for older residential areas in the westernmost part, large residential communities that were mostly developed after 1950 and continued into the late 1970 's dominate the landscape. Most of the larger developments in the eastern part are in the moderately deep and broad valleys and in the narrow coastal plain that joins the valleys. In the western part, the narrow coastal plain is replaced by a broad plain that aprons the lava flows of the Honolulu Group and the east flank of Diamond Head. Large residential subdivisions occupy this broad plain.

Lava flows of the Koolau Volcanics that are sparsely intruded by dikes in the east part and increasingly more intruded toward the west end are the principal rocks. The dikes are mostly north- and northeast-trending. Diamond Head, a tuff cone of the Honolulu volcanics rocks, dominates the landscape in the western part. The cone is about 2 miles offshore from a former shoreline. Kaimuki Basalt of the Honolulu Group overlies the former coastal plain and north flanks of Diamond Head. Kaimuki Basalt also overlies and abuts Mauumae Volcanics of the Honolulu Group near the north edge of the Kaimuki basaltic flows. 


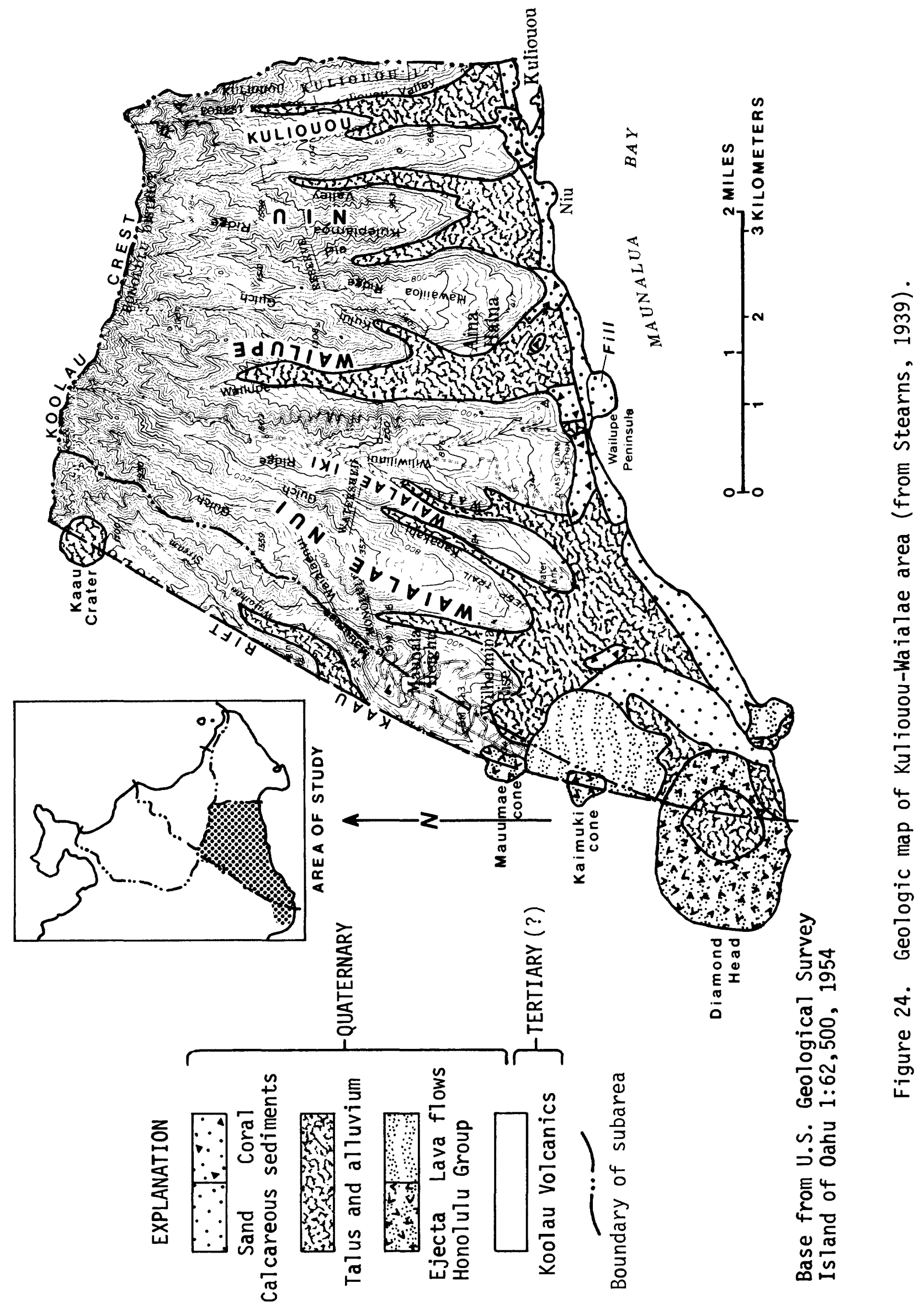


The main part of the Kuliouou-Waialae area is part of the original Koolau dome. Honolulu volcanic rocks are restricted to its west margin near Diamond Head. The major rift zone of the Koolau volcano lies approximately parallel to and just slightly north of the Koolau crest throughout the area. The minor, narrow Kaau rift, extends through Kaau Crater and Diamond Head. East of the Kaau rift, other rifts consisting of widely spaced dikes striking approximately normal to the major $r i f t$ zone subdivide the intruded lavas into rectangular cells. These dikes appear to extend from the crest of the Koolau Range toward the ocean (fig. 3). All the observed dikes of the rift zones belong to the Koolau Volcanics; dikes belonging to the Honolulu volcanic rocks have not been identified.

The geology of the area was described by Stearns (1935) and by Wentworth (1938). Both investigators recognized the relationship between the principal Koolau rift zone and the secondary rifts at right angles to it. Wentworth provided a detailed description of the lithology, structure and hydrologic characteristics of about a 5 square-mile sector that includes Waialae Nui, Kapakahi, Waialae $\mathrm{lki}$, and Wiliwilinui. The most promising ground-water resources exist in this sector.

Stearns (Stearns and Vaksvik, 1935) and Wentworth (1938) recognized 12 distinctive artesian basal-water areas on 0ahu (fig. 25). The region extending east of Palolo Valley to Wailupe Valley and south of the Koolau crest was called "isopiestic" Area 5 to distinguish it from the productive Honolulu "isopiestic" areas numbered 1 through 4 that extend westward from the axis of Palolo Valley to Red Hill ( $\mathrm{fig}$. 25). Area 5 was not considered a very promising prospect for ground-water development even though it was comparable in size to the other isopiestic areas in the Honolulu District. Its chief defects were identified as comparatively low rainfall and the absence of a continuous caprock wedge at and inland of the coast. Ground-water heads in Area 5 are about 10 feet above mean sea level compared to heads of more than 20 feet in Palolo Valley and to the west. 


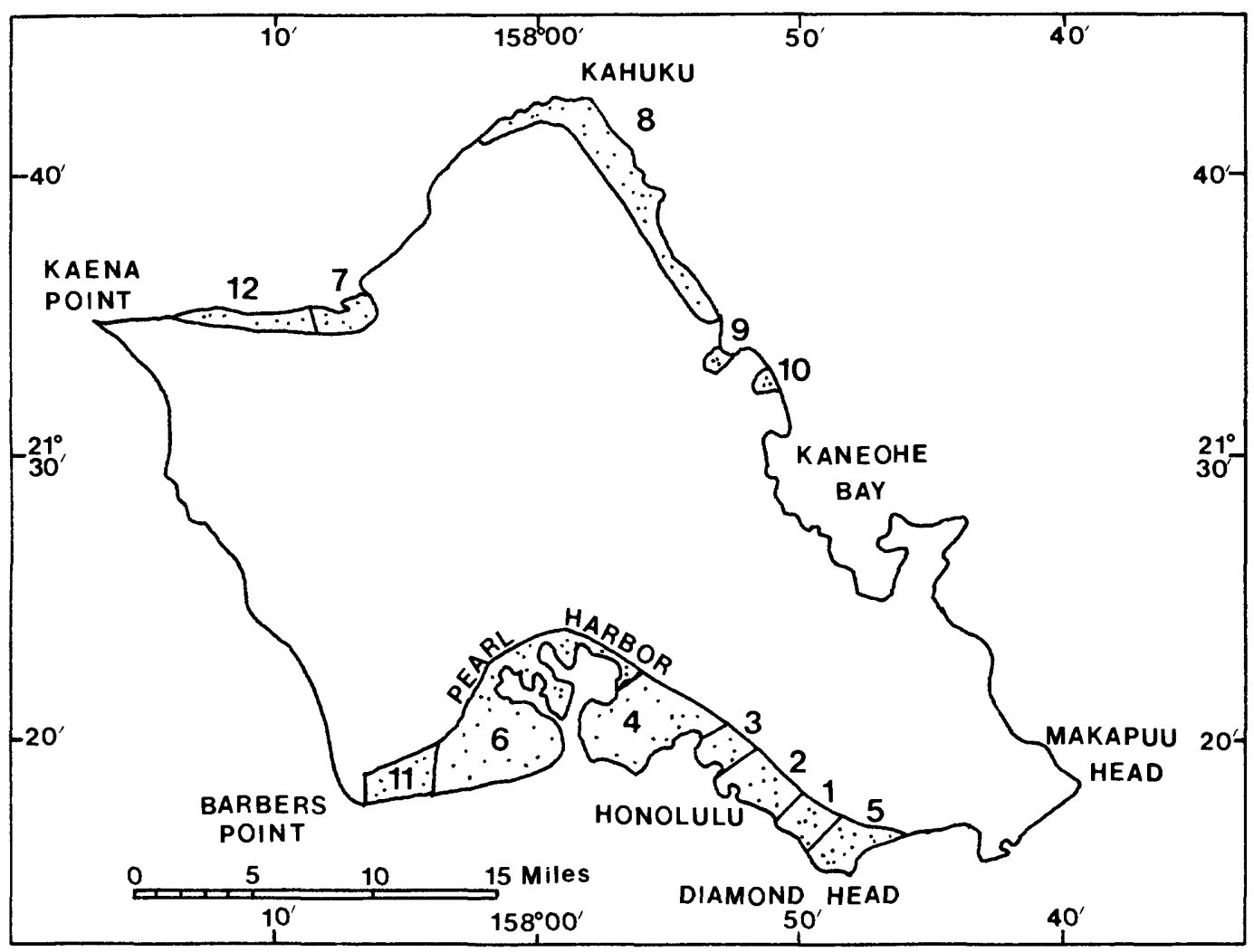

Figure 25. Isopiestic areas of Oahu (from Stearns and Vaksvik, 1935). 
The west boundary of Area 5 is the Kaau rift that strikes about N. $30^{\circ} \mathrm{E}$. as a band of intrusives, including a 50-to 200-foot-wide dike (Wentworth and Jones, 1940) in upper Palolo Valley. The $r$ ift zone may underlie part of Palolo Valley. It is the $r$ ift zone, rather than the valley fill, that forms the hydrologic barrier between Area 1 (Kaimuki) and Area 5.

Wentworth (1938) calculated the frequency of dike occurrences as a func$t i$ on of distance from the Kaau $r i f t$ and showed that the frequency decreased in an orderly fashion eastward. To Waiamao Stream in upper Palolo Valley, he assigned an average of 15 dikes per mile; in Waialae Nui, the first valley to the east of the rift, 10 dikes per mile; in Kapakahi, five dikes per mile; and in Waialae $\mathrm{Iki}$ and Wailupe, $1.5 \mathrm{miles}$ east of the rift, he assigned one dike per mile. All the dikes strike roughly normal to the principal Koolau rift along the Range crest.

Stearns (1939), as well as Wentworth, mapped individual dikes, but Wentworth also described large rounded intrusives, which he called "buds", and reported extensive sills in Waialae Nui. He recognized the "buds" as expansions of dikes and the sills as horizontal aberrations of essentially vertical dikes. Recent field work by the authors has corroborated Stearns' and Wentworth's interpretations of the rift zone and distribution and alinement of individual dikes.

Dikes are recognizable in stream valleys starting at an altitude as low as 300 feet in Niu Valley. In Waialae Nui, the first dike crops out about 2 miles inland at an altitude of 450 feet opposite the massive Palolo Dike of the Kaau rift, which was described by Wentworth (1938). In Wailupe, the first large dike visible in the stream is at an altitude of 770 feet, about 2-1/2 miles inland. The extension of this dike, or one having the same strike ( $N$. $25^{\circ}$ E.) and width ( 3 to 4 feet), crops out on Wiliwilinui Ridge 0.8 mile seaward of the stream outcrop. In Kapakahi, Waialae Iki and Waialae Nui dikes form the side walls of valleys in the streams' headwaters. 
The trend of the dikes east of the Kaau $r$ ift is essentially parallel to the rift. The predominant trend is N. $20^{\circ} \mathrm{E}$. to $\mathrm{N} .30^{\circ} \mathrm{E}$, though aberrations occur. The strike is also roughly parallel to the principal stream valley directions, in contrast to the windward side where dikes strike at right angles to the valleys. This difference in orientation profoundly affects the shape of the heads of stream valleys. On the windward side, amphitheater heads are formed as a result of intense erosion that leads to the collapse of dikes where they are normal to the valley, whereas on the leeward side, the drainage pattern produces narrow linear valleys parallel to the strike of the dikes. The Kaau rift and the dikes in southeast Oahu are shown in figure 3.

Coral and other marine sediments underlie the narrow coastal plain and lower parts of the valleys. The broad plain in the western part is underlain in the upper part by an extensive deposit of moderately well-cemented dune sand and in the lower part by an extensive sand beach. Most of the outcrops of the Honolulu volcanics rocks are underlain by coralline limestone.

The distribution of rocks is shown in a geologic map ( $f i g .24$ ) and in a structural section through Diamond Head, Kaimuki Crater, Puu Mauumae and toward Kaau Crater (fig. 26). The geology on the map was purposely extended west beyond the study area to a line adjoining Diamond Head, Kaimuki Crater, Puu Mauumae, and Kaau Crater. The structural section along this line probably outlines the central part of the Kaau Rift Zone. This rift is a major geologic structure and its control of the movement of ground water in southeast 0 ahu is highly significant.

\section{Streams}

Streams in the area are perennial only in their headwaters near the Koolau crest and only where they have cut deep enough to tap the dikeimpounded ground-water reservoirs. The magnitude of perennial flow in individual streams, however, also depends largely on how deeply the stream cuts into the dike-impounded reservoir. For instance, the perennial flow in the deeply cut Wailupe Gulch exceeds $0.15 \mathrm{Mgal} / \mathrm{d}$ at an altitude of 1,400 feet, but that of the stream in shallower Pia Valley in Niu, about a mile to the east, is only a trickle at the same altitude. 


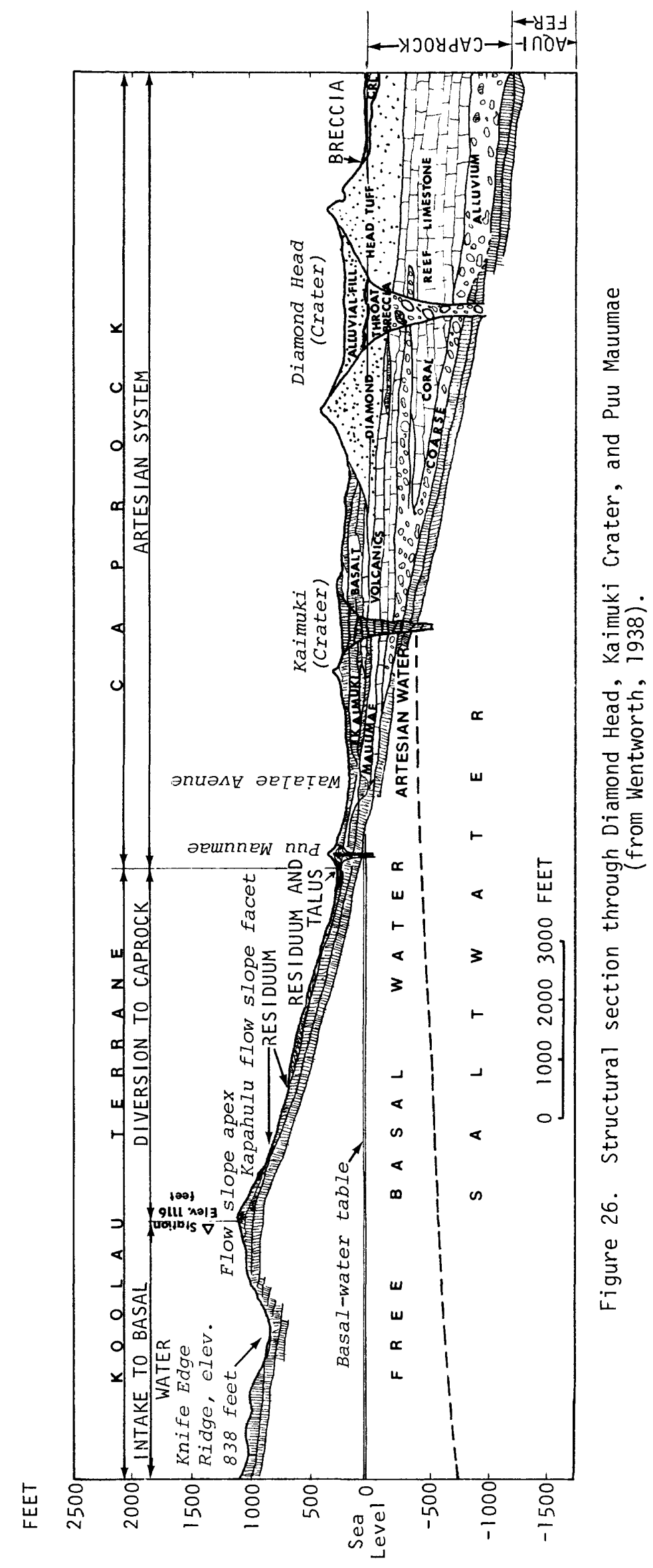


Owing to heavier rainfall in the western part, average flow is higher there than in the eastern part. Flow to the sea occurs only during and after periods of heavy rainfall. On the average, this flow to sea equals roughly a third of the area's average annual rainfall of about $36 \mathrm{Mgal} / \mathrm{d}$.

Owing to the highly flashy nature of the flow in streams and the lack of feasible sites for storing stream runoff, there is little likelihood that streamflow will be developed and utilized in the near future. The construction of small capacity dams that would be capable of retarding flow to promote infiltration may become feasible only after more ground water is developed.

Ground water

Dike-impounded water.--Ground water is impounded by dikes at and near the Koolau crest and for some distance downgradient of the crest. The downgradient extent of the dike-impounded reservoir is difficult to define because the dikes generally trend in the same direction as the flow of ground water. Impoundment, instead, is largely the result of intersecting dikes that form barriers. The degree of impoundment increases markedly with the number of intersections. The greater frequency of dikes in the west part generally favors more intersections and more opportunities for impoundment. Where there is little or no intersecting of dikes, the degree of impoundment depends on how much the trend of the dikes deviates from the direction of ground-water flow. 
The occurrence of dike-impounded water at higher altitude is also affected by the parallelism of the dikes to the ground-water flow direction. Even though numerous dikes intrude the Kuliouou-Waialae region, appreciable high-altitude water probably does not exist except near the Koolau crest. None of the streams are perennial nor show evidence of dike-impounded water in their middle and lower reaches, al though Wentworth (1938) reported persistent seepage at altitudes of 600 to 1,000 feet in Waialae Nui. This observation was not verified in recent field work. The only perennial flow observed during this investigation originates at an altitude above 1,120 feet in the main right branch of Wailupe Stream. A flow of 0.1 to $0.2 \mathrm{Mgal} / \mathrm{d}$ issues from a small amphitheater-like valley about 1,000 to 2,000 feet leeward of the crest. These high-altitude reservoirs are probably in dike compartments of the Kolau rift or in compartments where the minor rifts intersect the main rift.

Perched water.--The likel ihood that large reservoirs of perched ground water exist is small. There is no apparent discharge of any significant quantity of perched water nor is there any evidence from well-boring informa$t i o n$ sizable perched-water reservoirs

Basal water.--Except in lava flows that are intruded by dikes, basal water occurs in all rocks that extend below sea level. The most important and extensive reservoirs of basal water occur in the lava flows of the Koolau Volcanics. Coral limestone and dune sands are less extensive reservoirs but contain significant supplies of nearly fresh to brackish basal water.

The earliest ground-water study in the area was made by $H$. S. Palmer (1921) for the Bishop Estate. His study area extended from Waialae to Makapuu and included the investigation of 5 springs and 11 dug wells. The study described the occurrence of water and gave information on the chloride concentration of the water. In 1933 and 1934, C. K. Lum and others on the staff of the Honolulu Board of Water Supply collected and tabulated data on installations developing shallow ground water from Diamond Head to Koko Crater. A map showing the location of the data points, information on the chloride concentration of the water developed, and water levels in wells was included in the Board's Fifth and Sixth Biennial Reports (Honolulu Board of Water Supply, 1933-34, and 1935-36). 
In addition to studies by Stearns (Stearns and Vaksvik, 1935) and by Wentworth (1938), other investigations included Palmer (1955) on a shaft and tunnel in Wailupe, Watson (1956) on the practicability of basal-water development in the eastern part of Oahu, and Palmer (1958) on the geology and ground water east of Wailae. H. S. Palmer, in his 1955 study, showed the relationship between increase in tunnel draft to increase in chloride concentration of the water pumped at the Wailupe site. He recommended a second tunnel on the opposite side of the valley to permit a reduction of draft in the first in hopes of improving the quality of water there. L. J. Watson's study in 1956 gave an opinion that no worthwhile basal-water development was possible in the eastern part of Oahu. A review of Watson's report by H. S. Palmer agreed with Watson's opinion and gave the following as unfavorable contributing factors:

(1) Low rainfall;

(2) Narrowness of coastal plain which might act as a restraining caprock;

(3) Small bulk of lava rock;

(4) Deep reentrant valleys into the Koolau Range; and

(5) Dikes that trend in unfavorable directions.

Palmer, in his 1958 report, concluded that by and large, conditions for the occurrence of ground water in large amounts and of good quality are unfavorable between Waialae and Makapuu Head.

The occurrence and movement of basal water in the area appear to be controlled in part by the Kaau rift, dikes in minor rifts, caprock or the absence of it, valley fills, and possibly the former Koolau shoreline. Ground water occurs in freshwater lenses of two distinctly different thicknesses in the area and is abutted on the west by a lens of another distinctive thickness (fig. 27). The lenses are distinct in that they are significantly different in thickness. Based on head measurements taken in 1936, one is about 140 feet thick in the Kuliouou-Wailupe area on the east part; the other is about 400 feet in the Waialae area in the west part. In the abutting Palolo area to the west, the lens is about 1,000 feet thick. The thickness of the freshwater lens was calculated by multiplying the head in each area by the Ghyben Herzberg ratio of $1: 40$. 


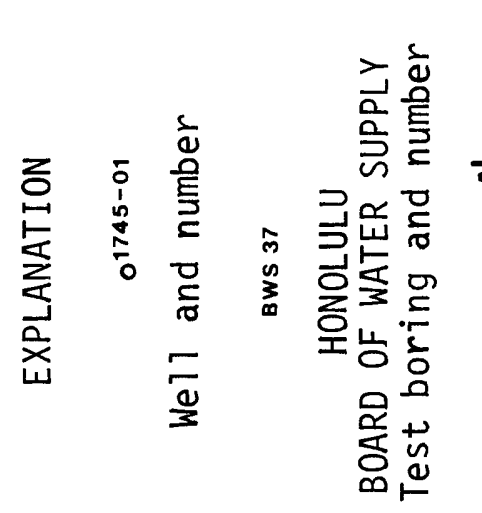
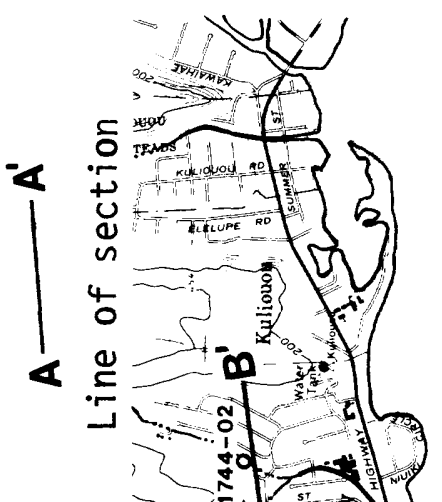

(1003)

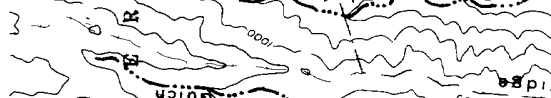

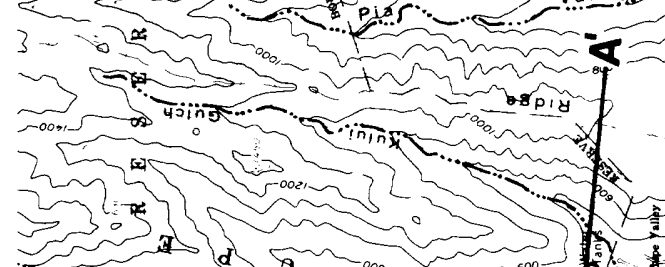

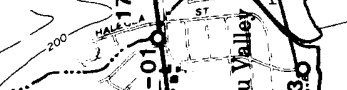

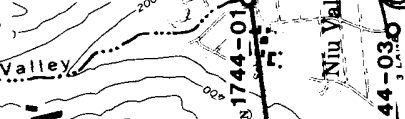

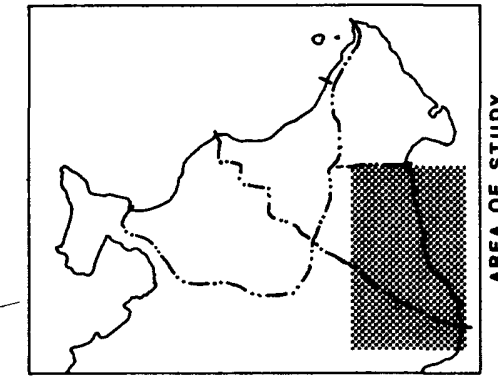

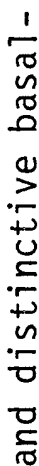

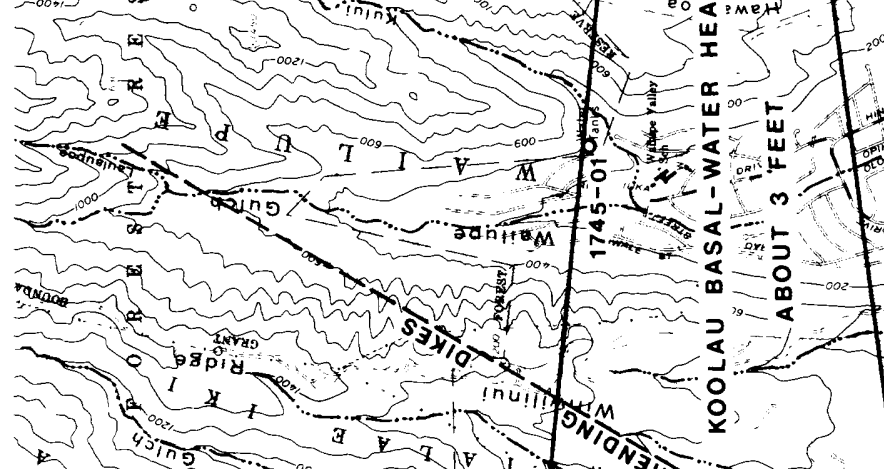

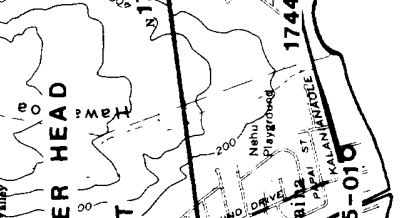

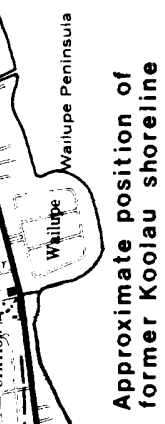
$8 \operatorname{los}^{2}$

s.t.

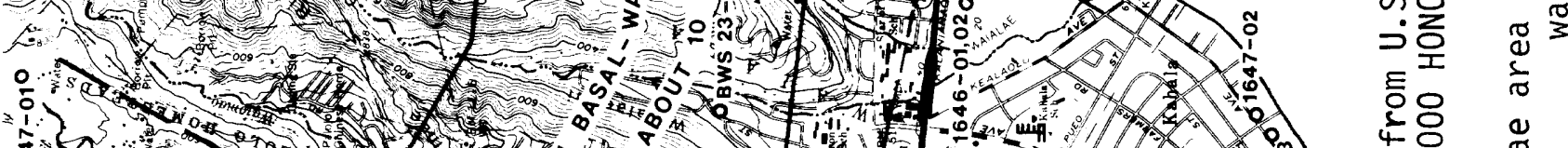
(1)

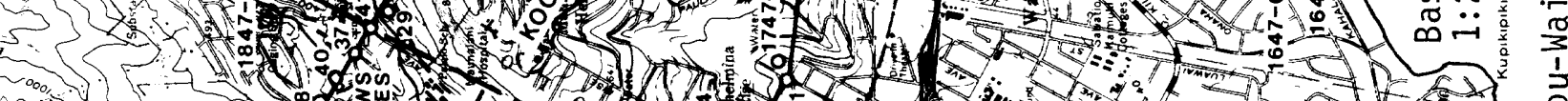
作 151)

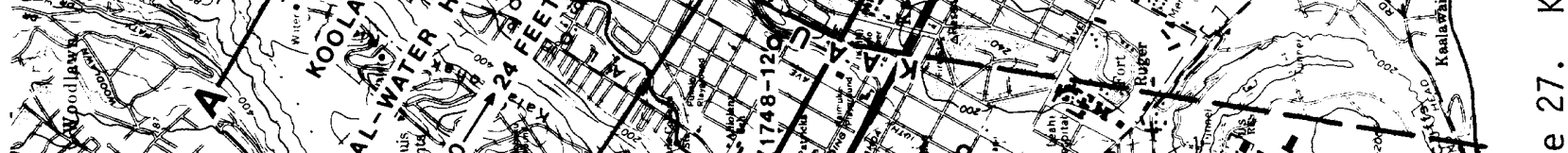

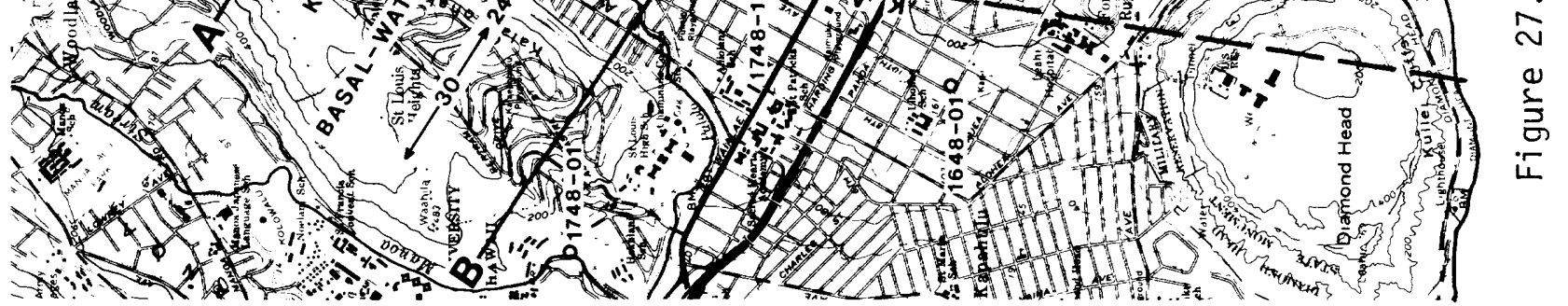


Figures 28 and 29 are sections showing relative thickness of these freshwater lenses in 1936. The sections were drawn across the volcanic spurs at altitudes of about 400 and 1,000 feet, respectively.

The principal deterrents to the east-west flow of ground water across the lava flows are concentration of dikes in the Kaau Rift Zone and a single, or set, of northeast-trending dikes that crop out about 1 mile north of section $A$ in Wailupe Gulch at an altitude of about 600 feet, and seaward in Wiliwilinui Ridge and in an unnamed gulch just west of the Ridge in Waialae lki (fig. 27). Caprock in areas fronting the Palolo and Waialae areas appears to be the principal deterrent to flow in the general direction of the lava slopes. Valleys generally are not cut deep enough to be major deterrents to groundwater flow across the lava slopes.

The ground-water reservoir east of the Kaau rift is hydrologically isolated from the reservoirs west of the rift. Dikes divide the region into small units having the general shape of rectangles parallel to the Kaau $r$ ift direction and extending from the coast to the crest of the Koolau Range. The Kaau $r$ ift behaves as an effective barrier to subsurface hydraulic connection between isopiestic Area 1 and isopiestic Area 5. Although heads in all "isopiestic" basins of Honolulu are highly correlated (Mink, 1980), figure 30 shows that correlation between heads in Area 1 and those in Area 5 is very poor. The data within Area 5 are too few to establish whether subsurface hydraulic connections among the dike compartments exist or not, but evidence suggests that the Waialae area west of Wailupe Peninsula is independent of Wailupe Valley and the sector east of $i t$. Within half a mile of the coast, the Waialae heads are greater than 5 feet, whereas those of Wailupe and eastward are less than 2 feet.

In 1936, the Honolulu Board of Water Supply attempted to augment the water supply for east Honolulu by constructing a shaft with an infiltration gallery in the Waialae area. A series of test holes had been located across Palolo Valley and into Waialae to trace the slope of the water table. Estimates of ground-water flow were made and a suitable site was selected for the shaft, which is numbered as 1747-02 in figure 27 (Wentworth, 1938). 


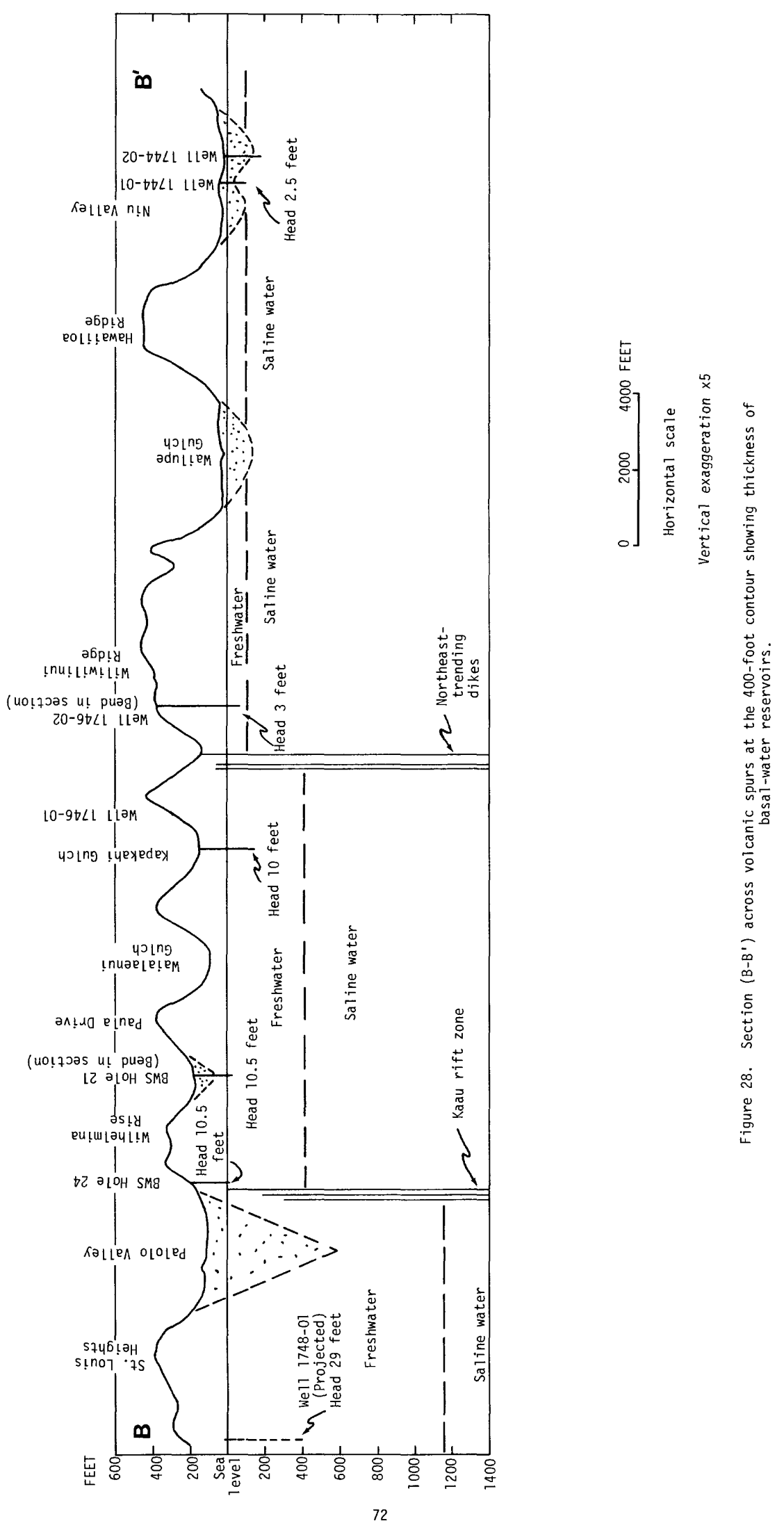




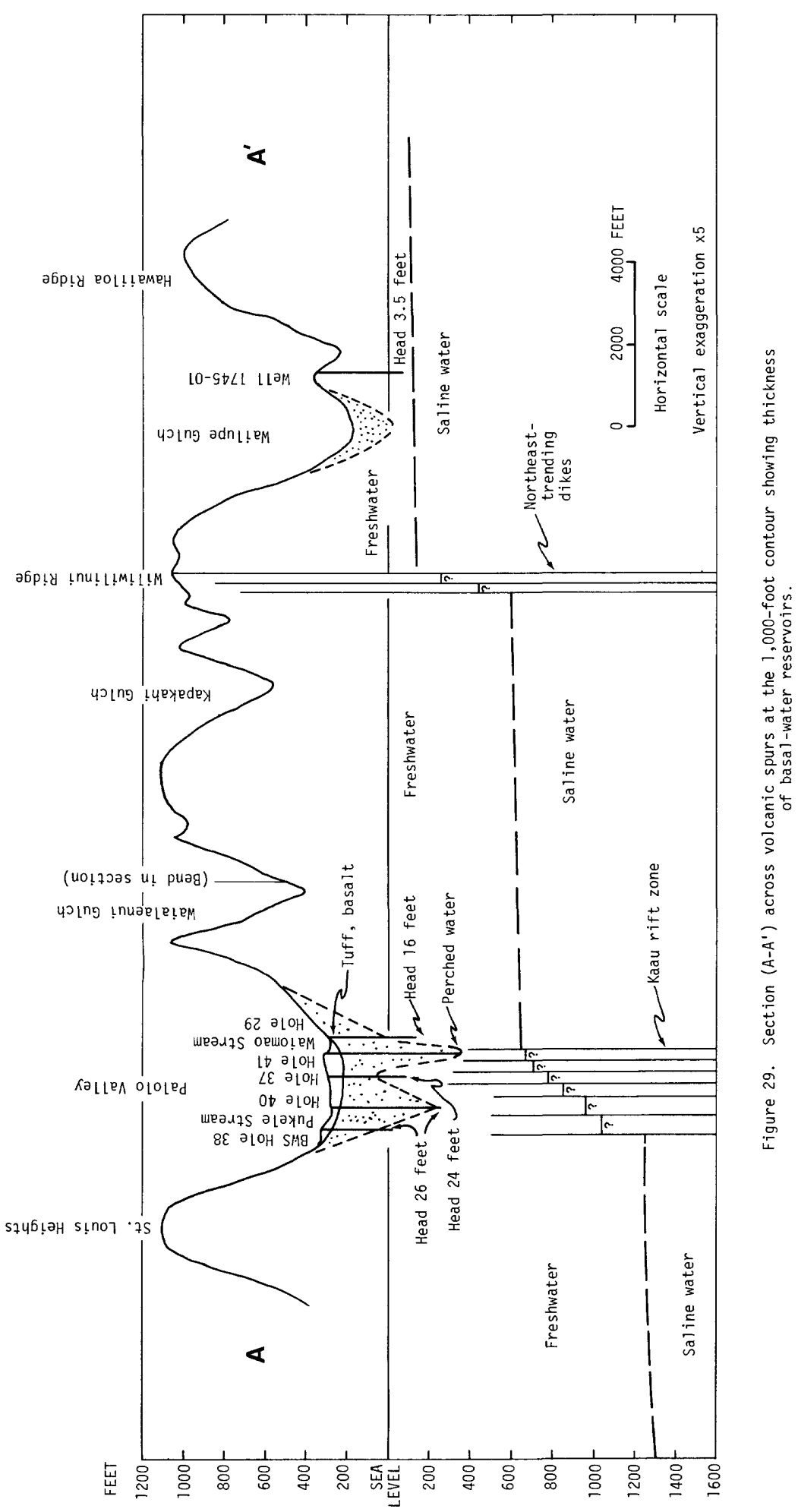




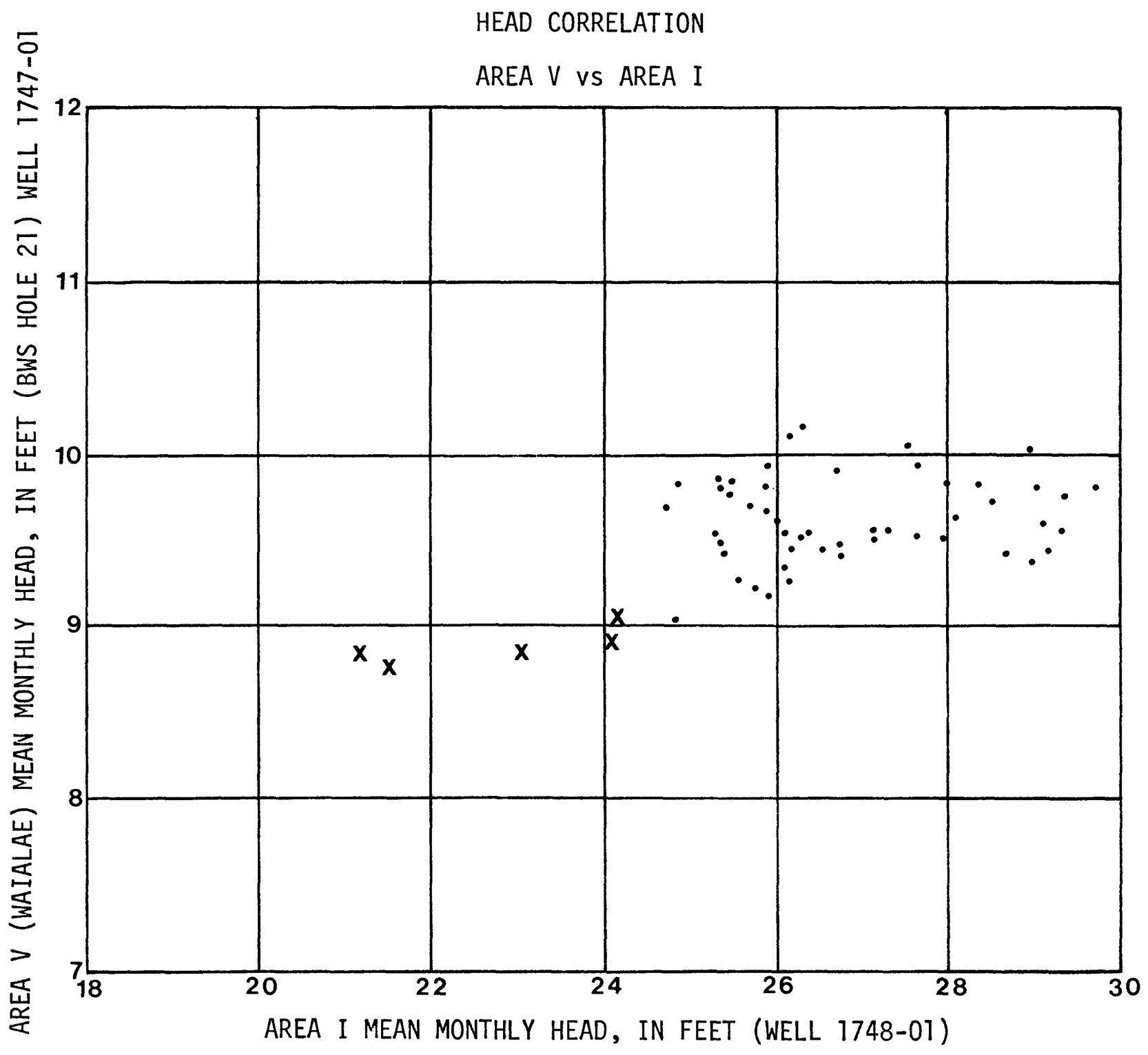

EXPLANATION

X Waialae pump test $1935-36$

- 1951-1960 Head measurements in feet above mean sea level

Figure 30. Head correlation between isopiestic areas 1 and 5 . 
In Palolo Valley, about 1.5 miles leeward of the Koolau crest, the head was 30.5 feet. In crossing the Kaau rift, it fell to 16.8 feet on the eastern side of Waiomao Stream, and then to 10.6 feet in Waialae about 1.5 miles inland. Weitworth concluded that the Palolo Valley sedimentary fill is the barrier between Area 1 and Area 5 and that the gradient in Area 5 was uniform and continuous at 5 feet per mile. Because he was aware that the rormal gradient in the basal lenses of southern 0 ahu is about one foot per mile, he concluded that more water flowed through Waialae than in the normal situation. He attributed the high gradient to spillage of water from the mountainous part of Area 1 into the Wailae region.

This gradient, however, is too high to represent unobstructed continuous flow in a basal lens in Hawaii, therefore, Wentworth overestimated the quantity of water moving seaward through Waialae. The high gradient probabiy reflects discontinuities to uniform flow. These discontinuities consist of the dikes of the Kaau-Diamond Head $r$ ift and the more widely spaced dikes east of the rift.

The Waialae shaft (well No. 1747-02) was constructed at the toe of Mauumae Ridge. The Board of Water Supply; under the direction of Wentworth, conducted the first organized regional pumping test in Hawai $i$ during construction of the shaft. The shaft, which at the time consisted of a sump excavated to sea level and a tunnel driven for 67 feet at an invert of 6 feet above sea level, was pumped continuously and constantly for 10 days (June $10-$ 20,1935 ) at 4,000 gal/min. Drawdown measurements were made at five drilled holes (observation wells) at distances of 690 to 5,750 feet from the pump. The only data still extant in accessible records are drawdowns at the end of 10 days of pumping. The essential data taken from wentworth's unpublished report on the Palolo-Waialae area (1938) are summarized in table 7.

Wentworth employed the steady-state Theim formulation for computing transmissivity. He assumed that steady-state had been reached after 10 days of pumping. Wentworth recognized the limitations of the method, and it is a tribute to his ingenuity that he introduced well hydraulic analyses to Hawai at such an early date. Table 7 includes Wentworth's computations of transmissivity and of hydraulic conductivity based on the assumption of a 200-foot zone of effective inflow. 
Table 7. Waialae shaft (1747-02) pump-test data and computations, June $10-20,1936$

[Constant pump rate of $4,000 \mathrm{gal} / \mathrm{min}$ for 10 days; data from Wentworth, 1938, p. 194]

\begin{tabular}{|c|c|c|c|c|c|c|}
\hline $\begin{array}{l}\text { Obser- } \\
\text { vation } \\
\text { well1/ }\end{array}$ & $\begin{array}{c}\text { Distance } \\
\text { from } \\
\text { pump } \\
(\mathrm{ft})\end{array}$ & $\begin{array}{l}\text { Obser- } \\
\text { vation } \\
\text { well pair }\end{array}$ & $\begin{array}{l}\text { Draw- } \\
\text { down } \\
(f t)\end{array}$ & $\begin{array}{l}\text { Hydraulic } \\
\text { conduc- } \\
\text { tivity } 2 / \\
(\mathrm{ft} / \mathrm{d})\end{array}$ & $\begin{array}{l}\text { Trans- } \\
\text { missiv- } \\
\text { ity } 3 / \\
\left(\mathrm{ft}^{2} / \mathrm{d}\right)\end{array}$ & $\begin{array}{l}\text { Recomputed } \\
\text { transmis- } \\
\text { sivity- } \\
\left(\mathrm{ft}^{2} / \mathrm{d}\right)\end{array}$ \\
\hline 21 & 690 & --- & 0.80 & ---- & ----- & ----- \\
\hline 23 & 2,320 & $21-23$ & .59 & 2,660 & 532,000 & 707,653 \\
\hline 24 & 2,610 & $21-24$ & .44 & 2,219 & 443,800 & 452,892 \\
\hline 22 & 4,650 & $21-22$ & .24 & 2,193 & 438,600 & 417,528 \\
\hline $1646-02$ & 5,200 & $21-(1646.02)$ & .45 & 3,516 & 703,200 & 707,187 \\
\hline 27 & 5,750 & $21-27$ & .08 & 1,818 & 363,600 & 360,885 \\
\hline
\end{tabular}

1/ Honolulu Board of Water Supply drill holes, except well 1646-02.

2/ Wentworth's calculation based on Theim steady-state formula and on the assumption of a 200-foot zone of effective inflow.

3/ Hydraulic conductivity converted to transmissivity for depth of flow of 200 feet. These figures were not included in Wenthworth's report (1938) but were the values obtained by the Theim method.

4/ Direct computation of transmissivity by Theim method. 
For comparison, the same data were substituted in the modified version of the nonsteady radial-flow Theis formulation (Lohman, 1972),

$$
s=\frac{Q}{4 \pi T} W(u)
$$

in which $s$ is drawdown, $Q$ is constant draft, $T$ is transmissivity $\left(f t^{2} / d\right)$, and $W(u)$ is called the well function in which $u=\frac{r^{2} s}{4 T t}$, where $s$ is specific yield, $t$ is time (days) and $r$ (feet) is distance from the pumping well. The above formula and its modification, although derived for confined conditions, is applicable to the Waialae shaft because the depth of flow is much greater than drawdown and the observation wells are at a distance from the pump greater than 1.5 times the depth of flow. Solutions for $T$ and $S$ were obtained graphically.

The best $\mathrm{fit}$ gives a $T$ of $470,000 \mathrm{ft}^{2} / \mathrm{d}$ and $S$ of about 0.05 . The $T$ value is similar to that of the steady state as expected for an aquifer of high transmissivity after 10 days of pumping. The method is approximate, the data base fragmentary, and the physical boundary conditions uncertain, so that the computed $T$ and $S$ values are not accurate by any means. They are, however, reasonable approximations. If the depth of flow is only 200 feet, the hydraulic conductivity determined by the Theim method is $2,350 \mathrm{ft} / \mathrm{d}$, a value comparable to that found in other flank-flow basalts in Hawaii.

The Wentworth steady-state approximations and the nonsteady-state estimate of $T$ and $S$ are strikingly similar to values computed from test results elsewhere in basal aquifers of 0ahu. Aquifer characteristics are not the fundamental constraint on water development in Area 5; they are as favorable as anywhere on the island. The limiting factor on the amount and rate of extraction of ground water is the physical boundaries of each aquifer. If dikes bound a small compartment, individual wells will have to be small. Large compartments permit higher capacities. However, most wells will be no more productive than about 500 gal/min for the most favorable set of conditions. In the low-head areas east of isopiestic Area 5, the principal limiting factor for ground-water extraction is intrusion or the threat of intrusion by upconing of saline water that underlies the lens of freshwater. 
The aquifer performance test conducted by Wentworth in 1935 was designed to determine hydraulic properties of the aquifer. There is no subsequent aquifer performance test to compare with it in the area. Three municipalsupply wells have since been drilled and were tested mainly to determine the capacity of the wells to yield water for the purpose of setting the pump and establishing operating pump rates. The chloride concentration of the water was carefully monitored during the test and in the low-head areas east of Area 5 , it is the principal concern in determining the operating pump rate.

Some comparison of hydraulic properties of aquifers can be made by the yield of weils as indicated by their specific capacities. The specific capacity of a well is its discharge expressed as a rate of yield in gallons per minute per foot of drawdown. For wells of different depths, the specific capacities can better be compared by dividing the specific capacities by the depths of aquifer penetration. Table 8 shows the relation between the specific capacity and the specific capacity per foot of aquifer penetration for wells that tap basaltic aquifers on Danu.

wentworth's test results showed that the hydraulic conductivity of the aquifer tapiea by the Waialae shaft (1747-02) was very high. Wells tapping these highly permeatie aquifers should have high values for specific capacity anci specific capacity per foot of aquifer penetration. The values should fall in the aquifer setting of dike-free flank flows (table 8 ).

Figure 31 shows the relation between pump rate in gallons per minute and drawdown in feet of the three municipal wells drilled in the Kuliouou-Waialae area since 1935. The average soecific capacicy, dquifer penetration, and the specific capacity per foot of aquifer penetration are shown below.

\begin{tabular}{|c|c|c|c|c|}
\hline Well & $\begin{array}{c}\text { Specific } \\
\text { capacity } \\
{[(g a l / m i n) / f t]}\end{array}$ & $\begin{array}{l}\text { Aquifer } \\
\text { pene- } \\
\text { tration } \\
(f t)\end{array}$ & $\begin{array}{c}\text { Specific } \\
\text { capacicy } \\
\text { per foot of } \\
\text { aquifer } \\
\text { pene- } \\
\text { tration } \\
{\left[(\mathrm{gal} / \mathrm{min}) / \mathrm{ft}^{2}\right]}\end{array}$ & Remarks \\
\hline $1745-01$ & 40 & 68 & 0.6 & $\begin{array}{l}\text { Probably weathered } \\
\text { aquifer. }\end{array}$ \\
\hline $1746-01$ & 5,000 & 142 & 35 & In high-head area 5 . \\
\hline $1746-02$ & 900 & 67 & 13 & in low-head area. \\
\hline
\end{tabular}


Table 8. Specific capacities and specific capacities

per foot of aquifer penetration for wells tapping

basaltic aquifers in Koolau Range

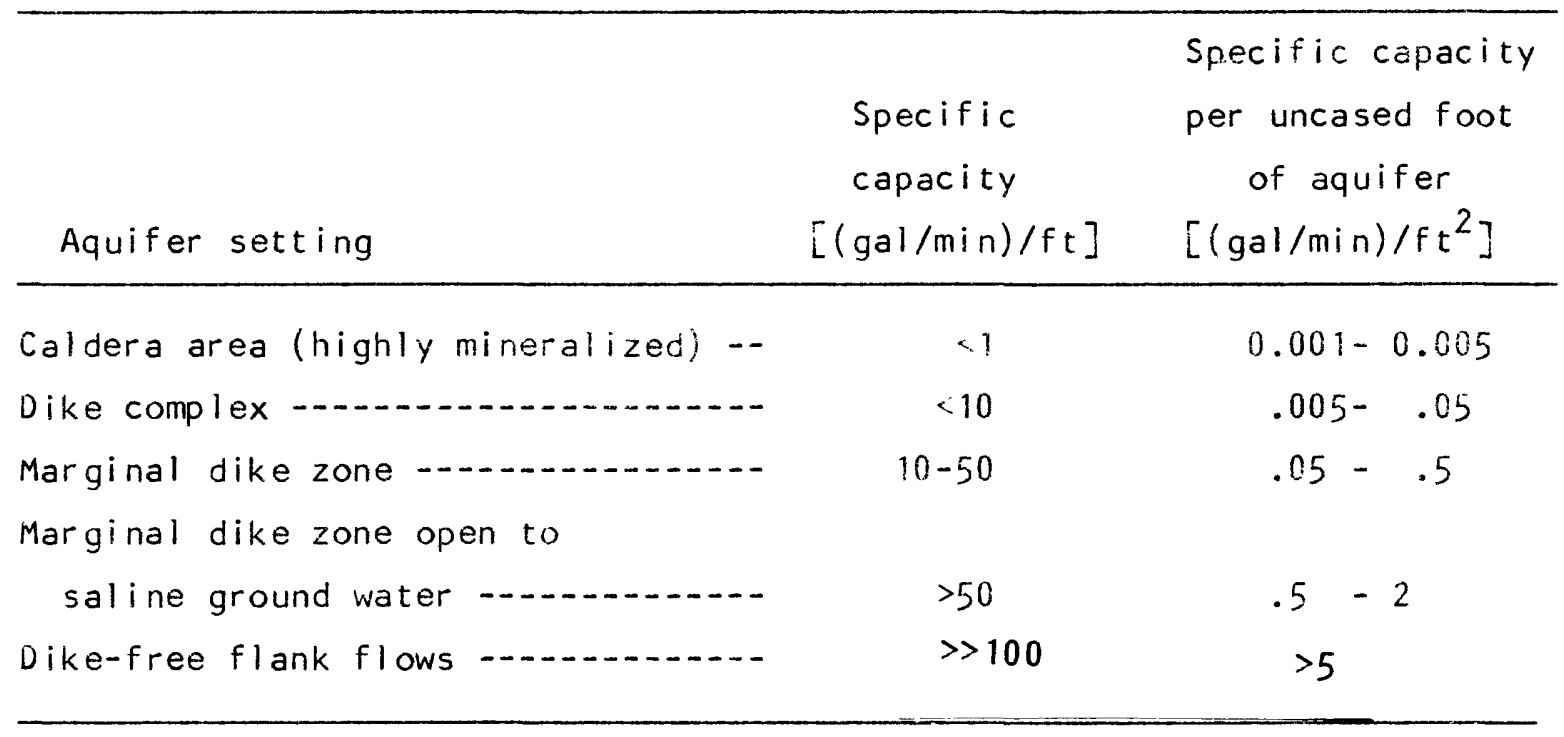

9 


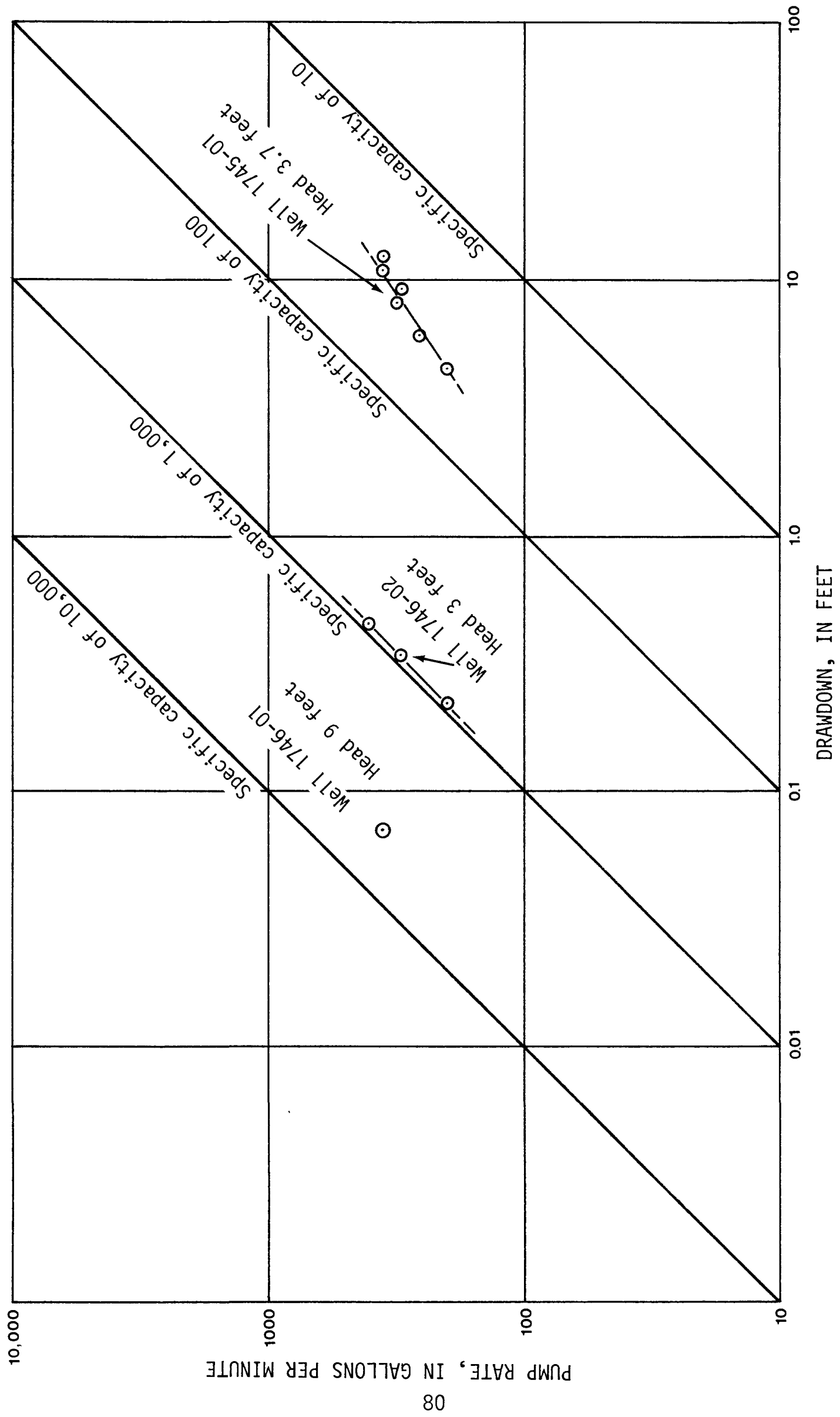

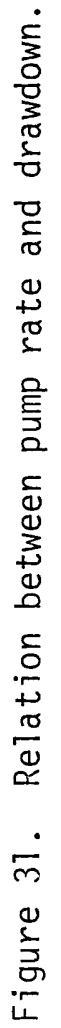


Wells 1745-01 and 1746-02 were purposely drilled to shallow depths below sea level because of their low respective heads of 3.7 and 3.0 feet. Well 1746-02 shows large values for specific capacity and specific capacity per foot of aquifer penetration that are indicative of an aquifer setting of dike-free flank flows. Well 1745-01, in contrast, shows small low values for these well-performance characteristics even though the geohydrologic setting appears to be similar to that of well 1746-02. The values for well 1745-01 are indicative of wells drilled in the marginal dike zone. Field investigations show some scattered dikes upgradient of the well that strike diagonally across Wailupe Valley but do not seem to be in sufficient numbers to account for the low specific capacity. The likelihood that the low values are indicative of deep aquifer weathering is strong. The well is drilled close to the confluence of two deep stream valleys.

Well 1746-01 is in isopiestic Area 5 as is the Waialae shaft. The extremely high specific capacity value is indicative of a well that taps an aquifer with a high hydraulic conductivity and transmissivity such as that tapped by the Wailae shaft. The well, when first drilled, tapped a thin layer of water with an unusually high chloride concentration of about 2,000 $\mathrm{mg} / \mathrm{L}$ sitting atop the basal water body. When the layer was cased off and the well initially pumped in 1968, the well yielded water with a chloride concentration of $250 \mathrm{mg} / \mathrm{L}$ that improved to $180 \mathrm{mg} / \mathrm{L}$ after being pumped at 350 gal/min for 59 hours, which equals a volume of about 1.25 million gallons. Later, when the well was pumped at $359 \mathrm{gal} / \mathrm{min}$ for 46 hours, a volume of about 1.0 million gallons, the chloride concentration decreased from 198 to 164 $\mathrm{mg} / \mathrm{L}$. The chloride concentration in 1980 was about $150 \mathrm{mg} / \mathrm{L}$ by which time pumping of the well as a municipal supply source was averaging about 200,000 gal/d.

Information on the wells in the Kuliouou-Waialae area is given in table 9. 
Tab!e 9. Wells in Kuliouou-Waialae area

\begin{tabular}{|c|c|c|c|c|c|c|c|c|c|c|c|c|c|c|}
\hline$\frac{\text { Well }}{\text { New }}$ & $\frac{\text { No. }}{01 d}$ & $\begin{array}{l}\text { Diam- } \\
\text { eter } \\
\text { (in.) }\end{array}$ & $\begin{array}{l}\text { Alti- } \\
\text { tude } \\
(\mathrm{ft})\end{array}$ & $\begin{array}{l}\text { Depth } \\
(f t)\end{array}$ & $\begin{array}{l}\text { Ca- } \\
\text { sing } \\
(\mathrm{ft})\end{array}$ & $\begin{array}{l}\text { Year } \\
\text { drilled }\end{array}$ & $\frac{\text { Head, }}{\text { High }}$ & $\frac{f t}{\text { Low }}$ & $\begin{array}{r}\text { Chlo } \\
\text { concentra } \\
\text { High }\end{array}$ & $\begin{array}{l}\text { ide } \\
\text { ion, mg/L } \\
\text { Low }\end{array}$ & Use & $\begin{array}{c}\text { Specific } \\
\text { capacity } \\
{[(\mathrm{gal} / \mathrm{min}) / \mathrm{f}}\end{array}$ & $\mathrm{ft}]$ & Remarks \\
\hline $1547-01$ & $1-4$ & 8 & -- & 70 & 46 & 1956 & --- & -..- & -.... & - & Pool & -...- & Log: & $\begin{array}{l}0-8 \mathrm{ft} \text { sand, } \\
8-70 \mathrm{ft} \text { coral } \\
\text { swimming pool. }\end{array}$ \\
\hline $1645-01$ & 440 & 2 & --- & 32 & --- & 1936 & 1.6 & $-\ldots$ & 629 & ---- & Lost & $-\cdots$ & Log: & $\begin{array}{l}0-21 \mathrm{ft} \text { marine } \\
\text { sediment, } 21-23 \\
\mathrm{ft} \text { coral, } 23-27 \\
\mathrm{ft} \text { sediment. }\end{array}$ \\
\hline $1646-01$ & $1 \mathrm{~B}$ & 8 & 18 & 120 & 43 & 1889 & 8.9 & 6.5 & 270 & 150 & $\begin{array}{l}\text { Irriga- } \\
\text { tion }\end{array}$ & ---- & U.S. & $\begin{array}{l}\text { Geological } \\
\text { Survey network } \\
\text { observation. }\end{array}$ \\
\hline $1646-02$ & $1 \mathrm{~A}$ & 4 & 18 & 131 & 100 & 1889 & 9.6 & 7.5 & -...- & -... & $\begin{array}{l}\text { Obser- } \\
\text { vation }\end{array}$ & $\ldots$ & Honol & $\begin{array}{l}\text { lulu Board of } \\
\text { Water Supply } \\
\text { observation. }\end{array}$ \\
\hline $1646-03$ & $1-5$ & 12 & 150 & 116 & $-\cdots$ & 1963 & $-\cdots$ & --- & 19,700 & 18,700 & Pond & 2,000 & Log: & $\begin{array}{l}0-109 \mathrm{ft} \text { marine } \\
\text { and terrestrial } \\
\text { sediments, } 109- \\
125 \mathrm{ft} \mathrm{lava,} \\
\text { pump } 166 \mathrm{gal} / \mathrm{min} \text {, } \\
\text { drawdown } 0.3 \mathrm{ft} \text {. }\end{array}$ \\
\hline $1646-04$ & $1 C$ & 12 & 10 & 31 & --- & 1968 & $-\cdots$ & ---- & 565 & 180 & $\begin{array}{l}\text { Irri- } \\
\text { gation }\end{array}$ & ---- & Log: & $\begin{array}{l}0-31 \mathrm{ft} \text { marine } \\
\text { sediment and coral. }\end{array}$ \\
\hline 1646 & --- & -- & -- & -- & --- & --- & $1 / 9$ & $1 / 7$ & - - & $-\ldots$ & $-\cdots$ & $-\cdots$ & BWS $d$ & $\begin{array}{l}\text { drill hole } 22 \text {, head } \\
\text { range 1951-60. }\end{array}$ \\
\hline $1647-01$ & $1-1$ & 2 & 8 & 70 & 0 & 1937 & ---- & $-\cdots-$ & $-\cdots--$ & ----- & $\begin{array}{l}\text { Aban- } \\
\text { doned }\end{array}$ & $-\cdots-$ & Log: & $\begin{array}{l}0-15 \mathrm{ft} \text { sand, } 15-24 \\
\mathrm{ft} \text { coral, } 24-69 \mathrm{ft} \\
\text { sandstone, } 70 \mathrm{ft} \\
\text { Kaimuki Basalt. }\end{array}$ \\
\hline $1647-02$ & $1-2$ & 8 & --- & 60 & 42 & 1954 & ---- & ---- & Salty & $-\cdots$ & $\ldots$ & Pool & Log: & $\begin{array}{l}0-10 \mathrm{ft} \text { sand, } 10-60 \\
\mathrm{ft} \text { coral, swimming } \\
\text { pool. }\end{array}$ \\
\hline $1647-03$ & $1-3$ & 8 & --- & 70 & 43 & 1955 & --- & ---- & Salty & ---- & $-\ldots$ & do. & Log: & $\begin{array}{l}0-10 \mathrm{ft} \text { sand, } 10-70 \\
\mathrm{ft} \text { coral, swimming } \\
\text { pool. }\end{array}$ \\
\hline $1743-01$ & 443 & -- & -- & 60 & $-\cdots$ & 1958 & $-\cdots-$ & $\ldots-$ & 2660 & $-\ldots$ & Pool & 190 & Log: & $\begin{array}{l}\text { Coral, pump } 130 \\
\text { gal/min, drawdown } \\
0.8 \mathrm{ft} \text {. }\end{array}$ \\
\hline $1744-01$ & 437 & 6 & 15 & 102 & 60 & 1938 & 2.1 & --- & 648 & 222 & $\begin{array}{l}\text { Aban- } \\
\text { doned }\end{array}$ & $\cdots+$ & Log: & $\begin{array}{l}0-52 \mathrm{ft} \text { sediment, } \\
52-64 \mathrm{ft} \text { weathered } \\
\text { rock, } 64-102 \mathrm{ft} \\
\text { lava. }\end{array}$ \\
\hline $1744-02$ & 436 & 6 & --- & 201 & 108 & 1939 & 2.1 & $-\ldots$ & 87 &.---- & do. & $-\cdots$ & Log: & $\begin{array}{l}0-159 \mathrm{ft} \text { weathered } \\
\text { rock, 159-201 ft } \\
\text { lava. }\end{array}$ \\
\hline $1744-03$ & 444 & 6 &.-- & 28 & 27 & 1951 & ---- & -..-- & $\ldots$ & -...- & -..... & $\ldots$ & Log: & $\begin{array}{l}\text { Coral, pump } 50 \\
\text { gal } / \mathrm{min} \text {, drawdown } \\
2.5 \mathrm{ft} \text {. }\end{array}$ \\
\hline $1745-01$ & --- & 14 & 379 & 435 & 406 & 1981 & 3.7 & $\cdots-$ & 75 & ---- & $\begin{array}{l}\text { Muni- } \\
\text { cipal }\end{array}$ & 35 & Log: & $\begin{array}{l}\text { Lava flows bottom } 39 \\
\text { ft casing, casing } \\
\text { slotted. }\end{array}$ \\
\hline $1746-01$ & $1-6$ & 12 & 156 & 305 & 193 & 1968 & e/ 10 & -..- & (2) & $-\cdots$ & do. & & Chlor & $\begin{array}{l}\text { ride concentration } \\
400 \mathrm{mg} / \mathrm{L} \text { when } \\
\mathrm{first} \mathrm{dr} \text { illed in } \\
1968,135 \text { to } 140 \\
\mathrm{mg} / \mathrm{L} \text { in } 1972 \text {. }\end{array}$ \\
\hline $1746-02$ & --- & 12 & 386 & 453 & $\underline{2} / 383$ & 1973 & $\mathrm{e} / 3$ & ---- & e/ 140 & ----- & do. & 100 & $30 \mathrm{ft}$ & t screen. \\
\hline $1747-01$ & $T-44$ & -- & --- & -- & $\ldots$ & 1935 & ----- & $-\cdots$ & & $\ldots$ & None & ---- & BWS D & $\begin{array}{l}\text { drill hole } 21 \text {, head } \\
\text { range. }\end{array}$ \\
\hline $1747-02$ & Sh-7 & -- & 160 & -- & --- & 1937 & $1 / 10.5$ & $1 / 9$ & $\underline{3} / 364$ & $\underline{3} / 73$ & $\begin{array}{l}\text { Muni- } \\
\text { cipal }\end{array}$ & $-\cdots$ & & $\begin{array}{l}1951-60.30-\text { degree } \\
\text { inclined } 8 \text { by } 8 \\
\text { shaft, } 5-\text { by } 7-f t \\
\text { tunnel } 67 \mathrm{ft} \text { long. }\end{array}$ \\
\hline 1747 & -- & -- & $\cdots$ & -- & --- & $-\cdots$ & $1 / 11$ & $1 / 9$ & $-\ldots-$ & $\ldots$ & $-\cdots+-$ & $\cdots$ & BWS O & $\begin{array}{l}\text { arill hole } 23 \text {, head } \\
\text { range } 1951-60 \text {. }\end{array}$ \\
\hline
\end{tabular}


Past and potential development

The water resources of isopiestic Areas 2 to 4 were plentiful with respect to Honolulu's needs, so there was no compelling reason to seriously probe the resources of Area 5. Nevertheless, the Honolulu Board of Water Supply made an effort in 1935 and 1936 to exploit the relatively high-head section in Waialae, just east of Palolo, by constructing a shaft with an infiltration gallery called the Wailae shaft. Its limited success discouraged further attempts at development until supply problems became pressing in Honolulu starting in the decade of the 1960's.

The demand for domestic water in this and the Hawai Kai areas increased from about $1 \mathrm{Mgal} / \mathrm{d}$ at the end of World War 11 to about $10 \mathrm{Mgal} / \mathrm{d}$ in 1980. The only other significant water use is irrigation of a golf links of about 0.25 Mgal/d. Of the total use, sources in the area supply about $1 \mathrm{Mgal} / \mathrm{d}$. There has been no significant increase in this supply for more than 30 years, even though a few new wells were drilled. A new municipal well in Wailupe will increase the supply in the area to about $1.4 \mathrm{Mgal} / \mathrm{d}$ when put into service in the near future. Nearly all the increase in demand for this period has been met by importing water from the Honolulu and Pearl Harbor areas.

Although ground-water supply in the area is limited and difficult to develop in significant quantities, the reservoir is isolated hydrologically from abutting reservoirs outside the area. This situation is advantageous in that development in or out of the area, regardless of its magnitude, will not significantly reduce underflow in or out of the area except to the sea. Existing supplies not fully developed are going to waste to the sea, conversely if overdevelopment induces seawater intrusion, the quality of water in the abutting reservoirs will not be degraded. 
An estimated sustainable ground-water yield figure of $5 \mathrm{Mgal} / \mathrm{d}$ was given in the State Water Commission's report to the Governor (1979) for the leeward area between Diamond Head and Makapuu Head. This represents about 10 percent of the average rainfall. If the rainfall in the Hawai $\mathrm{Kai}$ area is not considered, the $5 \mathrm{Mgal} / \mathrm{d}$ figure represents about 14 percent of the rainfall in the Kuliouou-Waialae area. Expected ground-water draft in the area of 1.4 $\mathrm{Mgal} / \mathrm{d}$, in comparison, is only about 4 percent of the rainfall. The prospect of utilizing a larger percentage of rainfall through ground-water pumpage is good. It will, however, necessitate the drilling of deep wells at high al titudes away from the coast in order to tap good quality water especially in low-head basal reservoirs. This action may require the abandonment of some marginal existing wells downgradient of the new wells in order to optimize development.

A favorable location to initiate additional development of ground water is in the western part where the basal-water head is close to 10 feet above mean sea level.

\section{Summary of Water Development in Southeastern Oahu}

Water use in southeastern Oahu is about $18 \mathrm{Mgal} / \mathrm{d}$ of which up to $4 \mathrm{Mgal} / \mathrm{d}$ is pumped from sources within the area. In addition more than $8 \mathrm{Mgal} / \mathrm{d}$ of highly brackish to saline water is pumped. Nearly all this supply is used by the Sea Life Park in the Makapuu area. Small supplies are developed for a quarry in the Waimanalo area and for several private swimming pools in the Kuliouou-Waialae area.

Past, and present development of water in the area is summarized in table 10 . 
Table 10. Summary of water development in southeastern Oahu

\begin{tabular}{|c|c|c|c|c|}
\hline Subarea & $\begin{array}{c}\text { Past and present } \\
\text { development }\end{array}$ & Remarks & $\begin{array}{l}\text { Potential for } \\
\text { development }\end{array}$ & Remarks \\
\hline $\begin{array}{l}\text { Maunawili } \\
\text { Valley } \\
\text { Above } \\
\text { Maunawili } \\
\text { ditch }\end{array}$ & $\begin{array}{l}\text { About } 1.8 \mathrm{Mgal} / \mathrm{d} \text { from } \\
\text { tunnels and springs } \\
\text { for delivery to Waima- } \\
\text { nalo by tunnel and } \\
\text { ditch system. }\end{array}$ & $\begin{array}{l}\text { Some leakage in } \\
\text { ditches. About } \\
0.4 \text { Mgal/d } \\
\text { leaks or flows } \\
\text { unused to below } \\
\text { ditch level. }\end{array}$ & $\begin{array}{l}\text { Deep wells drilled in } \\
\text { marginal dike zone to } \\
\text { be pumped only during } \\
\text { periods of heavy } \\
\text { demand. }\end{array}$ & $\begin{array}{l}\text { Tunnel flows will be } \\
\text { affected by pumping } \\
\text { and some even cease } \\
\text { to flow. Tunnels do } \\
\text { not appear favorable } \\
\text { for bulkheading. }\end{array}$ \\
\hline \multirow[t]{3}{*}{$\begin{array}{l}\text { Below } \\
\text { Maunawili } \\
\text { ditch }\end{array}$} & $\begin{array}{l}\text { Wells drilled into the } \\
\text { dike complex supplied } \\
\text { water to a state in- } \\
\text { stitution, two small } \\
\text { farms, and to augment } \\
\text { the municipal supply. }\end{array}$ & $\begin{array}{l}\text { All the wells } \\
\text { are inactive or } \\
\text { have been aban- } \\
\text { doned. }\end{array}$ & $\begin{array}{l}\text { Low flow of } 2.4 \mathrm{Mgal} / \mathrm{d} \\
\text { measured at entrance } \\
\text { of streams into Kawai- } \\
\text { nui Swamp. Low flow } \\
\text { is significantly lower } \\
\text { at the higher alti- } \\
\text { tudes. }\end{array}$ & $\begin{array}{l}\text { Low flow includes } 0.4 \\
\text { Mgal/d from above } \\
\text { ditch. }\end{array}$ \\
\hline & $\begin{array}{l}\text { Tunnels and springs } \\
\text { supplied water to } \\
\text { small farms and homes. }\end{array}$ & $\begin{array}{l}\text { Sources are pres- } \\
\text { ently not uti- } \\
\text { lized. Overflow } \\
\text { of these sour- } \\
\text { ces contributes } \\
\text { to low flow of } \\
\text { streams. }\end{array}$ & $\begin{array}{l}\text { Deep wells drilled in } \\
\text { dike complex are ex- } \\
\text { cellent means of } \\
\text { obtaining small local } \\
\text { supplies. }\end{array}$ & $\begin{array}{l}\text { Drawdown will be } \\
\text { large in pumping } \\
\text { wells. Water levels } \\
\text { generally near the } \\
\text { ground surface. }\end{array}$ \\
\hline & $\begin{array}{l}\text { About } 3 \text { Mgal/d were } \\
\text { pumped and transported } \\
\text { to Waimanalo area for } \\
\text { sugar cane irrigation. }\end{array}$ & $\begin{array}{l}\text { Tunnel and ditch } \\
\text { system inactive } \\
\text { and have been } \\
\text { abandoned. }\end{array}$ & $\begin{array}{l}\text { Restoration of Kawainui } \\
\text { Swamp supply to irri- } \\
\text { gate farms in Waima- } \\
\text { nalo area. }\end{array}$ & $\begin{array}{l}\text { Condition of tunnel } \\
\text { and ditch systems } \\
\text { unknown. }\end{array}$ \\
\hline $\begin{array}{l}\text { Sedimentary } \\
\text { rocks }\end{array}$ & $\begin{array}{l}\text { Water from wells } \\
\text { drilled for golf links } \\
\text { irrigation was too } \\
\text { salty. }\end{array}$ & Wells abandoned. & Small. & $\begin{array}{l}\text { Most recharge to sed- } \\
\text { imentary rocks is } \\
\text { intercepted by } \\
\text { Kawainui Swamp. }\end{array}$ \\
\hline $\begin{array}{l}\text { Waimanalo } \\
\text { area } \\
\text { Above } \\
\text { Maunawili } \\
\text { ditch }\end{array}$ & $\begin{array}{l}\text { Tunnels supply about } 0.7 \\
\text { Mgal/d for municipal } \\
\text { supply. }\end{array}$ & $\begin{array}{l}\text { Streamf low above } \\
\text { ditch of about } \\
0.3 \text { Mgal/d } \\
\text { flows into } \\
\text { ditch. }\end{array}$ & $\begin{array}{l}\text { Deep wells in marginal } \\
\text { dike zone drilled near } \\
\text { or in the existing } \\
\text { tunnels to be pumped } \\
\text { only during periods of } \\
\text { heavy demand. }\end{array}$ & $\begin{array}{l}\text { Tunnel flows will be } \\
\text { affected by pumping } \\
\text { and some even cease } \\
\text { to flow. Tunnels do } \\
\text { not appear favorable } \\
\text { for bulkheading. }\end{array}$ \\
\hline $\begin{array}{l}\text { Below } \\
\text { Maunawili } \\
\text { ditch }\end{array}$ & $\begin{array}{l}\text { First well drilled in } \\
1891 \text { tapped water in } \\
\text { deep sedimentary rocks. } \\
\text { Sugarcane mill supply } \\
\text { and later municipal } \\
\text { supply. }\end{array}$ & $\begin{array}{l}\text { Flowing artesian } \\
\text { well. Tempera- } \\
\text { ture about } 29^{\circ} \mathrm{F} \text {. } \\
\text { Well sealed in } \\
1970 \text {. }\end{array}$ & $\begin{array}{l}\text { Supply available in } \\
\text { deep sedimentary rocks } \\
\text { is unknown owing to } \\
\text { probable limited dis- } \\
\text { tribution of permeable } \\
\text { rocks at depth. }\end{array}$ & $\begin{array}{l}\text { Exploration not fea- } \\
\text { sible owing to high } \\
\text { cost of drilling } \\
\text { test borings. }\end{array}$ \\
\hline $\begin{array}{l}\text { Sedimentary } \\
\text { rocks }\end{array}$ & $\begin{array}{l}\text { Small shallow wells } \\
\text { dug in dune sands in } \\
\text { Waimanalo Village. } \\
\text { Fire-protection wells }\end{array}$ & Abandoned. & $\begin{array}{l}\text { Excellent. Shallow } \\
\text { wells or drainage } \\
\text { ditch to tap shallow } \\
\text { sand aquifer overly- } \\
\text { ing a clay horizon. }\end{array}$ & $\begin{array}{l}\text { Excellent quality. } \\
\text { Ground-water flux } \\
\text { estimated at } 28,000 \\
\text { to } 56,000 \text { gal } / d \text { per } \\
\text { shoreline mile. }\end{array}$ \\
\hline
\end{tabular}
tapping limestone in Bellows Field.

Sewage-effluent disposal wells for municipal sewage treatment plant.

Sources are presently not utilized. Overflow of these sourcontributes to low flow of

Tunnel and ditch system inactive and have been

Abandoned.

Active.
Deep wells drilled in minal dike zone to periods of heavy

ow flow of $2.4 \mathrm{Mgal} / \mathrm{d}$ sured at entrance e higher alti-

eep wells drilled in complex are exmeans of small loca Swamp supply to irrigate farms in Waima-

eep wells in marginal deep sedimentary rocks unknown owing to tribution of permeable

Excellent. Shallow ditch to tap shallow ing a clay horizon.
56,000 gal/d per 
Table 10. Summary of water development in southeastern 0ahu--Cont inued

\begin{tabular}{|c|c|c|c|c|}
\hline Sub area & $\begin{array}{c}\text { Past and present } \\
\text { development }\end{array}$ & Remarks & $\begin{array}{l}\text { Potential for } \\
\text { development }\end{array}$ & Remarks \\
\hline $\begin{array}{l}\text { Sediment ary } \\
\text { rocks-- } \\
\text { Cont inued }\end{array}$ & $\begin{array}{l}\text { Deep wells in dune } \\
\text { sands and } 1 \text { imestone } \\
\text { for quarry supply. }\end{array}$ & $\begin{array}{l}\text { Water brackish } \\
\text { owing to exces- } \\
\text { sive depth of } \\
\text { wells and heavy } \\
\text { pumping. }\end{array}$ & & \\
\hline $\begin{array}{l}\text { Makapuu } \\
\text { area }\end{array}$ & $\begin{array}{l}\text { Saltwater supply and } \\
\text { disposal wells tapping } \\
\text { lava flows of Honolulu } \\
\text { Group for mar ine-life } \\
\text { park. }\end{array}$ & $\begin{array}{l}\text { Well water is } \\
\text { far superior in } \\
\text { quality to } \\
\text { ocean water for } \\
\text { aquar ium use. }\end{array}$ & $\begin{array}{l}\text { Freshwater supply } \\
\text { very small and } \\
\text { limited to area } \\
\text { underlain by sedi- } \\
\text { ments at base of } \\
\text { cliffs. }\end{array}$ & \\
\hline \multirow[t]{2}{*}{$\begin{array}{l}\text { Hawa i i } \\
\text { Kai } \\
\text { area }\end{array}$} & $\begin{array}{l}\text { Early sources of water } \\
\text { were springs and } \\
\text { shallow dug wells. }\end{array}$ & $\begin{array}{l}\text { Except for seeps } \\
\text { from small } \\
\text { perched bodies } \\
\text { in tuff de- } \\
\text { posits all water } \\
\text { from springs and } \\
\text { and near the } \\
\text { coast was brack- } \\
\text { ish. All sources } \\
\text { have been aban- } \\
\text { doned. }\end{array}$ & & \\
\hline & $\begin{array}{l}\text { First deep well drilled } \\
\text { in } 1937.18 \text { more were } \\
\text { subsequent ly drilled } \\
\text { between } 1937 \text { and } 1966 . \\
\text { Most wells in Kalama } \\
\text { Valley for piggery and } \\
\text { truck-farm supply. }\end{array}$ & $\begin{array}{l}\text { Most wells } \\
\text { tapped basal } \\
\text { water in volca- } \\
\text { nic rocks. All } \\
\text { wells have been } \\
\text { abandoned. }\end{array}$ & $\begin{array}{l}\text { Good. A significant } \\
\text { supply of water in } \\
\text { the chloride-concen- } \\
\text { tration range of } 500 \\
\text { to } 1000 \mathrm{mg} / \mathrm{L} \text { is } \\
\text { available in western } \\
\text { part. }\end{array}$ & \\
\hline \multirow[t]{4}{*}{$\begin{array}{l}\text { Kuli ouou- } \\
\text { Waialae } \\
\text { area }\end{array}$} & $\begin{array}{l}\text { Springs and shallow dug } \\
\text { wells tapping calcare- } \\
\text { ous sediments abutting } \\
\text { the toes of volcanic } \\
\text { spurs provided most of } \\
\text { the water in the early } \\
\text { years. }\end{array}$ & $\begin{array}{c}\text { All sources have } \\
\text { been abandoned. }\end{array}$ & $\begin{array}{l}\text { Good. The potential } \\
\text { supply of domestic- } \\
\text { quality water is } \\
\text { difficult to deter- } \\
\text { mine owing to low } \\
\text { heads in much of the } \\
\text { area. Initiate de- } \\
\text { velopment in higher } \\
\text { head areas. }\end{array}$ & $\begin{array}{l}\text { Sustainable yield } \\
\text { figure of } 5 \text { Mgal/d } \\
\text { by State Water Com- } \\
\text { mission appears } \\
\text { reasonable. The } \\
\text { siting of wells will } \\
\text { be important factor. }\end{array}$ \\
\hline & $\begin{array}{l}\text { First } 3 \text { drilled wells } \\
\text { drilled in about } 1882 \text {. } \\
\text { Head about } 8 \text { feet. } \\
\text { Water brackish. }\end{array}$ & Wells are lost. & $\begin{array}{l}\text { Water supply in the } \\
\text { chloride-concentra- } \\
\text { tion range of } 250 \text { to } \\
1000 \mathrm{mg} / \mathrm{L} \text { range is } \\
\text { significantly greater } \\
\text { than } 5 \mathrm{Mgal} / \mathrm{d} \text {. }\end{array}$ & \\
\hline & $\begin{array}{l}\text { Two wells drilled about } \\
1889 \text { for ranch and } \\
\text { domestic supply in the } \\
\text { present site of Waialae } \\
\text { Golf Course. }\end{array}$ & $\begin{array}{l}\text { Wells } 1696-01 \text { and } \\
0.2 \text {. Draft about } \\
0.2 \mathrm{Mgal} / \mathrm{d} \text {. }\end{array}$ & & \\
\hline & $\begin{array}{l}\text { Shaft } 7 \text {, first municipal } \\
\text { well, constructed in } \\
1937 \text { followed by wells } \\
\text { drilled in 1968, 1973, } \\
\text { and 1981. }\end{array}$ & $\begin{array}{l}\text { Total municipal } \\
\text { draft in } 1980 \text { was } \\
305 \mathrm{Mgal} \text { or } \\
\text { about } 0.8 \mathrm{Mgal} / \mathrm{d} \text {. }\end{array}$ & & \\
\hline
\end{tabular}




\section{REFERENCES}

Austin, H. A. R., 1953, The availability of an adequate supply of water for the proposed house lot and farm lot subdivisions in Waimanalo with estimates of cost for required domestic and irrigation water system improvements and plan for operation of the irrigation system: Report to the Commissioner of Public Lands, Territory of Hawai 58 p.

Campbell, R. B., Chang, Jen-Hu, and Cox, D. C., 1959, Evapotranspiration of sugarcane in Hawai as measured by in-field lysimeters in relation to climate: Proceedings of International Society of Sugarcane Technologists Congress, 10 th, Mauritius Island 1959, p. 635-649.

Honolulu Board of Water Supply, 1935, Report of the Board of Water Supply to the Legislature of the Territory of Hawai $i$ and the Mayor and Board of Supervisors, City and County of Honoluu.

Honolulu Board of Water Supply, 1936, Sixth Biennial Report of the Board of Water Supply to the Legislature of the Territory of Hawai and the Mayor and Board of Supervisors, City and County of Honolulu.

Khan, I. A., 1974, An electric analog model study of waste water injection at Waimanalo, Oahu, Hawaian Islands: University of Hawaii, Honolulu. Master's thesis.

Lee, H. K., 1960, A survey of Maunawili Ditch and other water supply development in Maunawili Valley: Honolulu Board of Water Supply unpublished report dated December 1960 .

Lohman, S. W., 1972, Ground-water hydraulics: U.S. Geological Survey Professional Paper $708,70 \mathrm{p}$.

Lum, Daniel, 1969, Preliminary report on geohydrologic exploration for deep well disposal of effluent, Waimanalo Sewage Treatment Plant, Oahu: Hawaii Division of Water and land Development Circular C54, $14 \mathrm{p}$.

Lum, Daniel and Stearns, H. T., 1970, Pleistocene stratigraphy and eustatic history based on cores at Waimanalo, Oahu, Hawaii: Geological Society of America Bulletin, v. 81, p. 1-16, 7 figs., January 1970. 
Macdonald, G. A., 1956, The structure of Hawaiian volcanoes: Koninklijk Neder landsch Geologi sch--Mi jnbouwkundig Genootschap, Verhandelingen, v. 16 , p. $274-295$.

1972, Volcanoes: Englewood Cliffs, New Jersey, Prentice-Hall, Inc., $510 \mathrm{p}$.

Macdonald G. A., and Abbott, A. T., 1970, Volcanoes in the sea: University of Hawai i Press, Honolulu, Hawai i, 441 p.

McCandless, J. S., 1936, Artesian water in Hawaii: Honolulu, Hawaii, Advertiser Publishing Co., Ltd., 79 p.

Mink, J. F., 1962, Rainfall and runoff in the leeward Koolau Mountains, Oahu, Hawai : Pacific Science, v. 16, no. 2, p. 147-159.

1980 , State of the groundwater resources of southern Oahu: Board of Water Supply, City and County of Honolulu, $83 \mathrm{p}$.

Palmer, H. S., 1921, Groundwater resources of Maunalua, Oahu: Unpublished report to Land Department, B. P. Bishop Estate dated June 18, 1921. 1955, The 1925 water development shaft and tunnel of the HindClarke Dairy at Wailupe: Honolulu Board of Water Supply unpublished report dated November 30, 1955.

1958, Geology and groundwaters east of Waialae Oahu: Honolulu Board of Water Supply unpublished report dated September 30, 1958.

State Water Commission, 1979, Hawai's water resources, directions for the future: A report to the Governor of the State of Hawai i by the State Water Comission dated January 1979.

Stearns, H. T., 1939, Geologic map and guide of Oahu, Hawaii: Hawaii Division of Hydrography Bulletin 2, 75 p., $6 \mathrm{pl}$.

Stearns, H. T., and Vaksvik, K. N., 1935, Geology and ground-water resources of the island of Oahu, Hawaii: Hawai $i$ Division of Hydrography Bulletin 1, $479 \mathrm{p}$.

Swain, L. A., and Huxel, C. J., Jr., 1971, Relation of drainage problems to high ground-water levels, Coconut Grove area, Oahu, Hawaii: U.S. Geological Survey Open-File Report, $20 \mathrm{p}$.

Takasaki, K. J., Hirashima, G. T., and Lubke, E. R., 1969, Water resources of windward Oahu, Hawai : U.S. Geological Survey Water-Supply Paper 1894, 119 p. 
Takasaki, K. J., and Mink, J. F., 1981, Evaluation of major dike-impounded ground-water reservoirs, island of Oahu: U.S. Geological Survey OpenFile Report 81-1119, 139 p.

Watson, L. J., 1956, A review of the practicability of basal water development east of Manoa Valley: Honolulu Board of Water Supply unpublished report dated November 2, 1956.

Wentworth, C. K., 1938, Geology and ground-water resources of Palolo-Waialae District: Honolulu Board of Water Supply unpublished report, $274 \mathrm{p}$. 1951, Geology and ground-water resources of the Honolulu-Pearl Harbor area, Oahu, Hawai i: Honolulu Board of Water Supply, 111 p.

Wentworth, C. K., and Jones, A. E., 1940, Intrusive rocks of the leeward slope of the Koolau Range, Oahu: Journal of Geology, v. 48, p. 975-1006. 